\title{
Sustainable Accountability: A Dualist Vedic Perspective
}

By

Samuel David Stewart-Jacks

A thesis

submitted to the Victoria University of Wellington in fulfilment of the requirements for the degree of

Masters in Commerce and Administration in Accounting

Victoria University of Wellington 


\begin{abstract}
This thesis offers a theory of sustainable accountability informed by Vedic philosophy. Although Vedic philosophy is often described as the philosophy of ancient India, this thesis will explain how relative factors, such as time and place, do not exclude one from experiencing the taste of what is described as the ripened fruit of the tree that is the Vedic literatures. The implications the Vedas have for sustainability stem mainly from their alternative notions of the self and its needs. The Vedas hold that upon a correct evaluation of the needs of the self, an individual will be completely satisfied and will therefore not desire to live and consume in a way that is destructive to their surrounding environment and its inhabitants. Within the Vedic paradigm there are two main divisions of thought the dualist and non-dualist schools of philosophy. Because they differ in their conceptions of the self, these schools differ markedly in their notions of accountability, welfare and theories of sustainability and social change. Within the social accounting literature, a non-dualist theory of sustainable accountability has been given by Saravanamuthu (2006), but a dualist opinion has not yet been presented. This thesis seeks to introduce dualist Vedic philosophy and its theory of sustainability, and describe how a system of accountability could be constructed upon such a philosophy. In the past, academic scholarship has frowned upon sacred forms of knowledge such as the Vedas, and has considered their claims to be unverifiable. Therefore this thesis also asserts, using arguments from the critical realist ontology, that sacred forms of knowledge such as the Vedas should be admissible in academic circles.
\end{abstract}




\title{
Acknowledgements
}

\author{
om ajñ̄̄na-timirāndhasya \\ jūānāñjana-śalākayā \\ caksur unmīlitam yena \\ tasmai śri-gurave namah
}

First of all I must thank Devamrita Svami, for it is only by his grace that I have been fortunate enough to write on these topics. As described in the Śrī CaitanyaCaritāmrta:

brahmānda bhramite kona bhāgyavān jīva

guru-krsna-prasāde pāya bhakti-latā-bīja ${ }^{1}$

Next I must thank my supervisors - Judy Brown, Bhagwan Khanna and Trevor Hopper - for all of their expert guidance in presenting this difficult topic. Being such a professional academic, Judy was always able to understand exactly what I was trying to convey, even from my very rough draft material. Her advice was central to every part of this thesis. Furthermore I must also thank her for going out on a limb and supervising the writing of this thesis in the first place. Two years ago, when I first suggested this topic to her for an Honours thesis, she was very enthusiastic that I proceed. It is only with much of her help that I have finally presented it as a Masters thesis. I must also make special acknowledgement of Trevor Hopper, who so kindly volunteered to act as an informal supervisor to this thesis. Naturally, being such an esteemed academic, his input added enormous weight to my words, and also gave me confidence that educated persons would hear what I was trying to say. However it was not just Trevor's mere presence that gave this thesis whatever academic credibility it might have - it was also his very timely advice, especially concerning the admission of a Vedic worldview into Western academia. Finally, Bhagwan Prabhu must be thanked for all of his support, understanding and sadhu-sanga along the way:

\footnotetext{
${ }^{1}$ See Bhaktivedanta Svami (1996, Madhya-līlā verse 19.151).
} 


\author{
vāñchā-kalpatarubhuyaś ca \\ krpā-sindhubhya eva ca \\ patitānām pāvanebhyo \\ vaisnavebhyo namo namah
}

I must thank also thank Kala Saravanamuthu and Gregory Liyanarachchi for so nicely allowing me to cite the works they presented at the 2007 APRIA Conference in Auckland. I had better not forget my parents, Mike and Denise, for without their support I would not have been able to write this. I also cannot go without mentioning Mahavan Prabhu and Khadiravan Mataji, to whom I am so indebted. Thanks to them I am able to live the life that is described in the pages that follow. Special recognition must also go to Saci Dulal Prabhu for all of his encouragement, inspiration and example. The dedication he has shown for his own scholarly work has been very humbling, and I can hardly wait to absorb its nectar. There are also many others who have assisted me in so many ways - I have mentioned only the few who directly helped me in writing this. However to mention everyone will make this section too lengthy, so I must restrain from doing so. In any case, I have always thought that actions speak much louder than words, and so therefore the real acknowledgement for their help will be given more in what I do than what I say here.

Sam Stewart-Jacks

$21^{\text {st }}$ of January 2009

Auckland Brahmacari Ashram, New Zealand 


\section{Table of Contents}

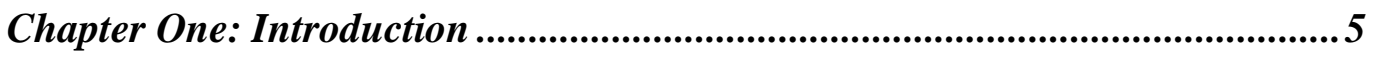

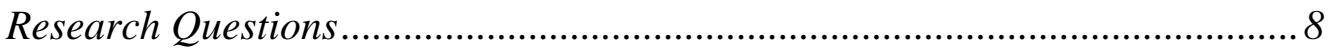

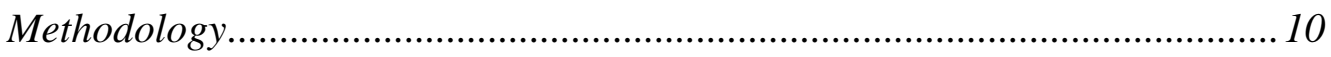

Chapter Two: Accountability and Vedic Philosophy ........................................... 15

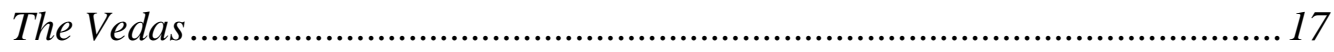

Accountability in Religious Organisations .......................................................20

Vedic Philosophy and the Sacred Secular Divide ..........................................2 27

Chapter Three: The Vedas and Western Scholarship .....................................33

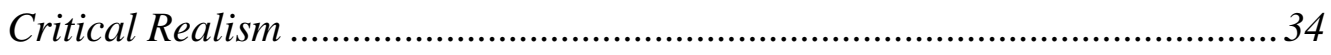

Critical Realism and Sacred Forms of Knowledge .........................................4 43

Chapter Four: Non-Dualist Vedic Accountability ............................................55

The Self in Non-Dualist Vedic Philosophy.....................................................55

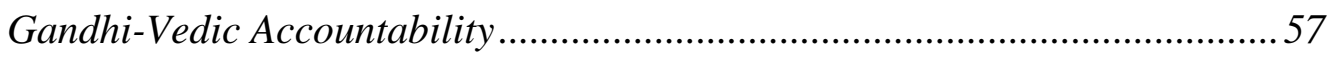

The Riverlands Citrus Industry's Satyagrahic Journey ................................62

Chapter Five: Dualist Vedic Philosophy ....................................................66

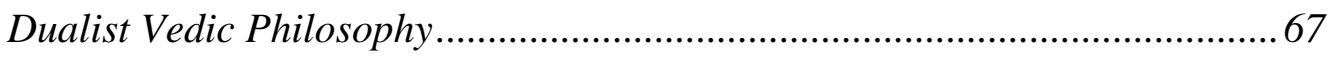

The Self in Dualist Vedic Philosophy........................................................... 71

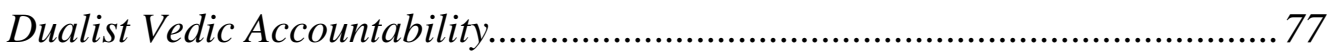

Chapter Six: Counteraction by Detachment ..................................................82

The Non-Material Identity of the Self............................................................ 82

Accounting for the Non-Material Identity of the Self ..................................... 88

Chapter Seven: Interaction by Attachment .....................................................99

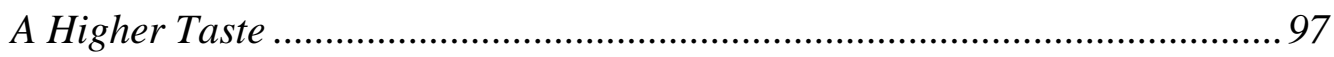

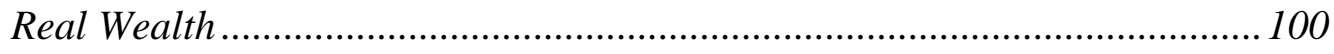

Accounting for the Pleasure of the Supreme ............................................... 105

Chapter Eight: Dualist and Non-Dualist Accountability .................................111

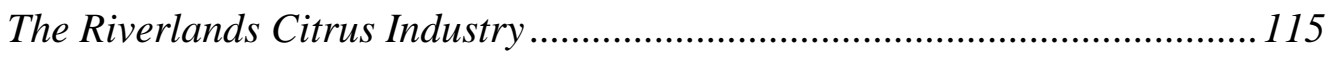

Chapter Nine: Operational Feasibility and Research Implications...............119

Chapter Ten: Concluding Comments....................................................................123

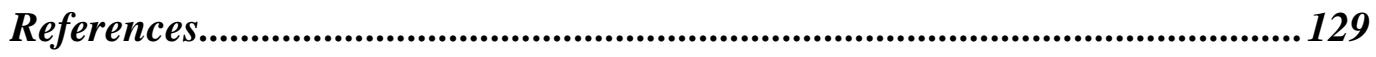




\section{Chapter One: Introduction}

The term accountability, as described by Roberts and Scapens (1985), refers in its broadest sense to the giving and demanding of reasons for conduct. Accounting systems, they explain, are instead the rules and resources that are drawn upon in the practical application of accountability. Velayutham and Perera (1996), in turn, have observed that the specifics of a system of accountability will depend upon a society's metaphysical conception of the self. They state:

“... accounting is a socio-technical activity in which peoples' values and patterns of thinking play an important part... differences [between Western and Eastern theories of management and accountability] are related to different metaphysical notions of the self and freedom, which provide the basis for the development of cultural values in a particular society, such as those identified by Hofstede (1980), and are central to the understanding of the nature and purpose of organisations and the role of accounting in society" (Velayutham and Perera, 1996, p. 66).

In rendering accounts, then, presupposed notions of the self determine whom one is accountable to, what one is accountable for, and what particulars are regarded as relevant to decision-making. Shearer (2002), for instance, explains that neoclassical economics regards individuals as self-interested. Because selfinterested behaviour is generally considered by neoclassical economics as welfare maximising behaviour (Gray, 2006), Shearer claims that mainstream accounting places no requirement on the corporate entity to recognise any reporting obligation other than the pursuance of its own interests. Thus, because of a particular conception of the self embedded in the neoclassical paradigm (self-interested), the accounting framework is configured a certain way (accountability only for self-interested behaviour). It follows, then, that in order to change the configurations of whom one should be accountable to, and what one should be accountable for, due consideration needs to be given to the underlying notions of the self in mainstream accountability.

This thesis gives a theory of sustainable accountability informed by a Vedic conception of the self. Not very well known, and not very well understood in Western scholarship, Vedic philosophy has its roots in India, and is the largest 
mass of philosophical knowledge descending from the ancient world (Rosen, 2006). The Vedas give an extraordinarily detailed description of the self and its needs that has profound implications for disciplines such as accounting and economics. As Chakraborty and Chakraborty (2007) state, for instance, traditional Hinduism encouraged economic practices for the purposes of nourishing the body and the mind, as well as the soul. Other proponents of Vedic economics have also said that the Vedas advocate the pursuit of wealth in an ethical manner (Kanagasabapathi, 2007; Sharma and Talwar, 2004, 2005, 2007; Sihag, 2007), so as to satisfy material needs but not unlimited material wants (Biswas, 1998). Therefore, in light of calls for more ethical and ecological systems of accounting, a theory of accountability based upon the Vedic conception of the self has much to contribute, as Chakraborty and Chakraborty have implied:

\footnotetext{
"The comprehensive approach of the ancient Hindu mind in identifying such an ensemble of economic functions is noteworthy. They wisely realised that the generation of wealth without proper allocation would only mean lopsided economic growth without social harmony. Hence, care was taken to channelize wealth for organic development of the society" (2007, p. 716).
}

To date, few scholars have recognised the potential of the Vedic paradigm to inform social and ecological economics and accounting and Vedic philosophy remains relatively unknown to influential commentators, or, where it has been acknowledged, it is not yet taken seriously. Yet, as the above authors have implied, the Vedas give unique and practical insights to many significant issues such as sustainability, social welfare, responsibility for the other, social change, ethics and the interdependence of humans and the ecosystem. Therefore there is a gap in the literature that expands across many different subjects where the Vedas can provide valuable comment. As implied by Velayutham and Perera (1996), alternative forms of accountability begin with alternative conceptions of the self. Hence this thesis contributes to the sustainability literature by offering a theory of accountability based upon the Vedic conception of the self.

Within the Vedic paradigm there are, broadly speaking, two divisions of thought - the dualist, or dvaitic schools of thought; and the non-dualist or 
advaitic schools (Saravanamuthu, 2006, 2007). The differences arise from different interpretations of the Vedic literatures. Differences in thought also exist in other religious codes - to consider Islamic banking practices, for instance, different interpretations of the Quran play a significant role in how Islamic banking is conducted (Nathan and Ribiere, 2007). As a very brief summary, the non-dualist Vedic schools of thought assume no distinction between the self and the remainder of the universe, and thus they hold that everything is interconnected, or everything is one. According to non-dualist philosophy, the perception that one's self is different from the universe is regarded as maya, or illusion. The dualist schools of philosophy, on the other hand, assert that there is a significant difference between the self and matter, and, in addition, there is also a distinction made between the self and the Supreme Person, in that both eternally maintain their own individual and personal existences. As will be seen, to refer to God as the Supreme Person is a more accurate rendering of the Vedic conception of God. In the Vedic literatures God is described as personal, and is called by many different names, with His principle name being Krishna. According to the dualist philosophy, then, maya - illusion - is to consider the self to be material in origin, and to be the Supreme Person.

A non-dualist theory of accountability has been given by Saravanamuthu (2006, 2007) based upon the theorisations of Mohandas Gandhi, which are themselves located in non-dualist Vedic philosophy (Ghosh, 2007). However, given the differences between dualism and non-dualism, the non-dualist theory of accountability offered by Saravanamuthu is not representative of all Vedic philosophy. Because of their differences in conceptions of the self, the dualist and non-dualist schools differ markedly in their notions of accountability, welfare, and theories of sustainability and social change. Therefore this paper presents a theorisation of sustainable accountability from a dualist school of Vedic philosophy called Gaudiya-Vaisnavism. Although this philosophy has more in common with dualist philosophy than the non-dualist, it agrees with certain non-dualist claims as well. A more thorough description of the similarities and differences between dualism and non-dualism, and their implications for a Vedic theory of accountability is presented in Chapter Two. A comparison between the Vaisnava and non-dualist theorisations of 
accountability, as described by Saravanamuthu (2006, 2007) is given in the eighth chapter.

As this thesis explains a dualist conception of Vedic accountability, it must also describe the dualist opinion of the sacred secular divide that has received much attention in the accounting and religion literature. Several commentators have stated that accounting represents a profane activity at odds with religious values, and is therefore only externally used in religious organisations (Booth, 1993; Laughlin, 1988, 1990; Lightbody, 2000). Further studies, however, have revealed that accounting has often been used to support religious goals and practices, which suggests that for some religious institutions no division between the sacred and the secular exists (Irvine, 2005; Jacobs, 2005; Jacobs and Walker, 2004). These different positions will be located within a Vedic understanding of the sacred secular divide, alongside the GaudīyaVaisnava perspective.

\section{Research Questions}

Saravanamuthu $(2006,2007)$ formulates a theory of accountability upon Gandhi's theorisations for socio-political change, which are themselves located in the advaitic paradigm. Saravanamuthu's developments of Gandhi's paradigm are therefore taken as an embodiment of advaitic accountability, and thus they represent the necessary benchmark to compare the two accountings. As explained, because the dvaitic and advaitic schools differ in their conceptions of the self, their respective notions of welfare, ethics, and sustainability also differ. This thesis seeks to compare and evaluate the ability of each to provide a sustainable form of accounting. The first research question therefore becomes:

1. What would be the significant features of a theory of accountability informed by dualist Vedic philosophy, as represented by GaudīyaVaisnavism?

A second research question then becomes:

2. How does a dualist theory of accountability, represented by the Gaudīya-Vaisnava school of Vedic philosophy, differ to the non- 
dualist theory of the Ghandi-Vedic paradigm, as presented by Saravanamuthu (2006)?

Outside of religion and philosophy departments, Vedic philosophy is exceedingly rare in Western scholarship. Indeed, secular orthodox and heterodox economics journals rarely publish papers exploring the relevance of religious scriptures, and there are few books explaining such issues (Beed and Beed, 2004). In the social accounting literature, McKernan and Kosmala (2007) comment that despite a recent expansion of interdisciplinary research, relatively few scholars have attempted to connect accounting and religion. The reason, claimed by McPhail, Gorringe and Grey $(2004,2005)$, is that religious or sacred forms of knowledge have, in the past, been frowned upon by academic scholarship as a legitimate form of knowledge because they lack any apparent falsifiability. McPhail et al. (2004) nonetheless claim that there is a growing awareness that modern and postmodern critiques of theology, when applied reflexively back on themselves, show the claims of science and post-modernism to be no less spurious or arbitrary than those of religious belief systems. Oslington (2000) also shows that several well-respected philosophical positions have come to similar conclusions. This paper, in describing non-dualist Vedic philosophy and its theory of accountability, draws upon the latest spiritual developments of Roy Bhaskar (2000) in his philosophy of critical realism. Elsewhere, authors have used critical realism to defend religious knowledge as academically acceptable and to cast doubt on positions sceptical of religious knowledge (Archer, Collier and Porpora, 2004). Since this thesis will draw on Bhaskar's spiritual developments of critical realism to defend the academic credibility of sacred forms of knowledge, particularly the Vedic teachings, the third research question becomes:

3. What arguments can be presented from a critical realist position that will establish the academic credibility of sacred forms of knowledge, in particular Vedic philosophy?

Using the arguments put forward by Archer et al. (2004), this thesis contributes to work begun by Oslington (2000) to establish sacred forms of knowledge as 
academically acceptable. The arguments this thesis will add, however, are derived from critical realist ontology, and thus they strengthen the position that sacred forms of knowledge are admissible in rational debate.

\section{Methodology}

As mentioned above, within the dualist and non-dualist Vedic schools of thought there are further subdivisions. The dualist school adopted here is that of Gaudīya-Vaisnavism. ${ }^{2}$ It is selected because this school, or sampradāya, emphasises the necessity of adopting the specific mood required to understand Vedic teachings. In the Bhagavad-Gittā, the text that contains the essence of Vedic philosophy, Krishna explained to Arjuna the reasons why he should fight in the Battle of Kuruksetra. In the final verses, when Krishna asks Arjuna if he has understood all of His instructions, Arjuna replies that he has, and that he was prepared to fight (Bhaktivedanta Svami, 1989, verse 18.72-73). Therefore, in order to understand the Vedic texts and injunctions, one has to adopt the same mood that Arjuna had in the Bhagavad-Gìtā. As Bhaktivedanta Svami states, this applies to any material situation:

"If we want to take a particular medicine, then we have to follow the directions on the label. We cannot take the medicine according to our whim or the direction of a friend. It must be taken according to the directions written on the label or the directions given by a physician. Similarly, the Bhagavad-Gìtā should be taken or accepted as it is directed by the speaker Himself. The speaker of the Bhagavad-Gītā is Lord Śrī Krsna" (Bhaktivedanta Svami, 1989, p. 3). ${ }^{3}$

This mood is described by Krishna in the Gitta at the beginning of the fourth chapter, where Krishna tells Arjuna that he will understand the Vedas because he is bhakto 'si me sakhā - Krishna's friend and devotee. The exact verse reads:

\footnotetext{
${ }^{2}$ As explained in the second chapter, the Gaudiya-Vaisnava school accepts some tenets of both dualist and non-dualist Vedic philosophy. It is, however, more closely associated with dualist Vedic lines of thought, and therefore in this thesis it is also described as one of the dualist schools.

${ }^{3}$ Due to there being different sized publications of the Bhagavad-Gìtā As It Is, by A. C. Bhaktivedanta Svami, the page numbers to quotations may not always match up between copies.
} 


\author{
sa evāyam mayā te 'dya \\ yogah proktah purātanah \\ bhakto 'si me sakhā ceti \\ rahasyam hy etad uttamam
}

\begin{abstract}
"That very ancient science of the relationship with the Supreme is today told by Me to you because you are My devotee as well as My friend and therefore you can understand the transcendental mystery of this science" (Bhaktivedanta Svami, 1989, verse 4.3). This qualification for understanding the Vedas is not limited to the Bhagavad-Gìtāa, but is inherent throughout all Vedic literatures. The last verse of the Śvetâśvatara Upanisad, for example, implies the same requirement:
\end{abstract}

\title{
yasya deve parā bhaktir \\ yathā deve tathā gurau \\ tasyaite kathitā arthāh \\ prakāśante mahātmanah
}

\begin{abstract}
"Only unto those great souls who have implicit faith in both the Lord and the spiritual master are all the imports of Vedic knowledge automatically revealed" (Śvetâśvatara Upanisad, verse 6.38, quoted in Bhaktivedanta Svami, 1989, p. 361). Bhaktivedanta Svami therefore writes that one who is trying to understand the Bhagavad-Gìtà should at least theoretically accept Śrī Krishna as the Supreme Person, and with that submissive spirit they can understand the Bhagavad-Gītā. As he states:
\end{abstract}

"Bhagavad-Gìtā should be taken up in a spirit of devotion. One should not think that he is equal to Krsna, nor should he think that Krsna is an ordinary personality or even a very great personality. Lord Śrī Krsna is the Supreme Personality of Godhead. So according to the statements of the Bhagavad-Gìtā or the statements of Arjuna, the person who is trying to understand the BhagavadGìtāa, we should at least theoretically accept Śrī Krsna as the Supreme Personality of Godhead, and with that submissive spirit we can understand the Bhagavad-Gìtă" (Bhaktivedanta Svami, 1989, p. 6). 
Essentially, then, in order to understand the Vedas, a submissive attitude is required, but this does not imply that one should follow the Vedic injunctions blindly or without scrutiny. Indeed, up to that point in the Gìtā, Arjuna had asked many questions of Krishna.

In the social accounting literature, the notion that one must adopt the correct mood to understand the Vedas is absent, and non-dualist schools even suggest the contrary:

"The [Bhagavad] Gita...the deeper you dive into it, the richer the meaning you get...With every age the import the words will carry new and deeper meanings...the seeker is at liberty to extract...any meaning he likes so as to enable him to enforce in his life the central teaching [of embracing responsibility for the other]" (Gandhi, 1961, p. 456 quoted in Saravanamuthu, 2007, p. 38).

Gandhi's approach to the Bhagavad-Gìtā illustrates a non-submissive attitude to understanding the Vedas. Rather than trying to understand the purpose for which the Bhagavad-Gìta $\bar{a}$ was spoken, Gandhi attempts to use the philosophy of the Gìta to justify his motive of freeing India from British rule. Gandhi was heavily influenced by ideas of non-violent resistance put forward by the Russian novelist Tolstoy, who himself was a pacifist (Hellmon, 1994). Later, Gandhi employed similar notions of satyagraha and ahimsa in his political activism to free India from the British (Saravanamuthu, 2006). In the Bhagavad-Gītā, however, Krishna urges Arjuna to fight a fratricidal war, which was contradictory to Gandhi's inclinations towards non-violent resistance. Therefore Gandhi was forced to claim that the Bhagavad-Gìtā is simply an allegory that illustrates the inner war between good and evil that takes place in all humans. Thus, where the Bhagavad-Gìtā reads dharma-ksetre kuru-ksetre (the place of pilgrimage at Kuruksetra) in the first verse (Bhaktivedanta Svami, 1989, verse 1.1), Gandhi interprets kuru-ksetre to mean this body, even though Kuruksetra is an actual place of pilgrimage in India that many thousands of people visit every year. As he states: 
"Everything related to every hero in the Ramayana or Mahabharata I do not take literally... Nor do I regard Rama and Krishna as portrayed in the two poems as infallible beings. They reflect the thoughts and aspirations of their ages. Only an infallible person can do justice to the lives of infallible beings. One can, therefore, only take the spirit of these works for guidance only, the letter will smother one and stop all growth" (Gandhi, 2001, p. 47).

Because Gandhi did not approach the Gìtā with the same submissive spirit that Arjuna had, he could not understand its teachings. For instance, according to the Gìtā, the title mahätma - which was conferred upon Gandhi - refers to one who is fully engaged in the service of God - not to one who strives for political independence (Bhaktivedanta Svami, 1989, verse 9.13). This thesis claims that the Gaudiya-Vaisnava school of philosophy adopts the correct method of understanding Vedic teachings as it most authentically represents the Vedas, and more faithfully uses them as a source than non-dualist works. As the only Vedic work on social accounting is in the non-dualist tradition it is important to establish a dualist Vedic approach.

To compare both forms of Vedic accountability, this thesis must first describe Saravanamuthu's (2006) developments of Gandhi's advaitic paradigm, which acts as a benchmark for the comparison. Prior to this, however, it is necessary to give an introduction to Vedic philosophy itself, as some readers may not be well acquainted with the Vedas, or may harbour false conceptions of what is contained in them. Bhaskar's spiritual developments of critical realism are used to describe non-dualist Vedic philosophy, as he explains and justifies advaitic Vedic thought in a way comparable with Western philosophy. It is therefore necessary to also describe the fundamental tenets of critical realism. Then Saravanamuthu's non-dualist accountability is described and subsequently a dualist position and the comparison of the two accountings are given.

Altogether this thesis has ten chapters. This first has been introductory it has outlined the need for a dualist opinion of accountability and described the methodology underpinning this thesis. The second chapter briefly introduces Vedic philosophy and reviews the accountability literature relevant to a Vedic approach. Chapter Three describes the critical realist arguments for accepting the Vedas in rational discourse. The fourth chapter explains non-dualist 
accountability drawing upon Saravanamuthu's (2006) and Bhaskar's (2000) explanations of advaitic Vedic philosophy. The fifth chapter describes dualist philosophy and the sixth and seventh describe a theory of accountability informed by such philosophy. This leaves the comparison for the eighth chapter, and the ninth examines the operational feasibility of dualist Vedic accountability. Finally, some concluding comments are made in Chapter Ten. 


\section{Chapter Two: Accountability and Vedic Philosophy}

Translated into English, the Sanskrit word Veda means knowledge. The term Vedic, then, refers to the literature and teachings of the Vedas. In contemporary social economics, the Vedas have been described as the ancient philosophy of India, and they are often referred to as the scriptures that provide the basis for the various branches of Hinduism (Biswas, 1998; Chakraborty and Chakraborty, 2007). The Vedas, however, do not limit their applicability only to those born in a certain geographical location, or only to those who ascribe to the Hindu faith. The words Hindu and Hinduism are not found in any of the Vedic scriptures, and nor are such terms included in the Sanskrit language. The word Hindu is a descendent of the Indo-Iranian word sindhu, which, when translated into English, means river. The word sindhu was used to refer especially to the Indus River and the culture along its expansive valley. When Persian travellers returned to their homeland, having explored the Indian subcontinent, and subsequently mentioned the Sindhu River, the phonetic peculiarities of their native language changed the word Sindhu into Hindu. Due to this, the people of the Indus Valley became known as Hindus, which was slang for the people who live by the Sindhu River (Rosen, 2006). The word India also has its origins in the same river. Upon crossing the Sindhu River when invading the subcontinent in $325 \mathrm{BCE}$, Alexander the Great renamed the Sindhu Indus because it was easier for the Greek army to pronounce (Tigunait, 1983). The term later grew to refer to the entire subcontinent. Therefore both the terms Hindu and India have no connection with the intended scope of Vedas.

Instead of limiting their applicability to the residence of a particular time or place, the Vedas see the entire human race as their intended audience (Druhl, Langstaff and Monson, 2001; Sharma and Talwar, 2007). ${ }^{4}$ Various theological commentators have presented views on economics and accounting from different religions on the strength that their respective faiths are exceptionally widespread. Liyanarachchi (2007), for instance, states that an estimated 360 million of the world's population are Buddhist, and Beed and Beed (2004) cite that a third of

\footnotetext{
${ }^{4}$ One of the fundamental tenets of dualist Vedic philosophy is that the self, or the living entity, is not their material body. Gender is dependent only on the type of body the living entity inhabits, but the living entity itself is gender-neutral. Throughout the Bhagavad-Gìtā, though, Bhaktivedanta Svami refers to the living entity as a 'he', and the same terminology is adopted in this thesis.
} 
the world's population claim Judeo-Christian allegiance. The dualist side of Vedic philosophy, however, does not make the same appeal to popularity as a justification for its significance to accounting - although it is possible to do so, as more than 600 million people in India alone identify themselves as Vaisnavas of some kind (Rosen, 2006). To justify its applicability to economics and accounting, dualism instead refers to the Vedic concept of sanatana-dharma, which translates into English to mean the eternal function of the living entity. The English word religion is slightly different from the Vedic concept of sanätanadharma. The word religion conveys the idea of faith, and faith may change. One can have faith in a particular doctrine, and he may change his faith and adopt another, but sanatana-dharma refers to that activity which is eternal, and cannot be changed. Dualist Vedic philosophy asserts that the sanātana-dharma, the eternal occupation of the living entity, is to render service:

"... one friend serves another friend, the mother serves the son, the wife serves the husband, and the husband serves the wife and so on.... The politician presents his manifesto to the public to convince them of his capacity for service. The voters therefore give the politician their valuable votes, thinking that he will render valuable service to society. The shopkeeper serves the customer, and the artisan serves the capitalist. The capitalist serves the family, and the family serves the state in terms of the eternal capacity of the eternal living being" (Bhaktivedanta Svami, 1989, p. 19).

Finally, the living entity simply renders service to the desires of his own mind and senses, and thus there is no exception to this rendering of service. To render service, then, is the sanātana-dharma of the living entity. One may profess to belong to a certain faith with reference to a particular time and circumstance and thus claim to be a Hindu, a Muslim, a Christian, a Buddhist or an adherent of some other sect. A Hindu may change his faith to become a Muslim or a Christian, yet in all circumstances such change does not affect his eternal occupation of rendering service.

Dualist Vedic philosophy, then, justifies the presentation of its theory of accountability as an opinion concerned with sanatana-dharma. As explained later, dualism asserts that if the living entity renders service to the Supreme 
Person Whom he is a part of, then he will be most satisfied. Because all living entities render service regardless of their particular faith, dualist Vedic philosophy is non-sectarian, and thus dualist accountability can be applied across any peoples, regardless of their circumstantial designations. While some religious commentators appeal for a particular type of accountability for those who adhere to that particular faith (Lewis, 2001), dualist Vedic accountability is intended for the welfare of all.

\section{The Vedas}

If this thesis is to give a theory of accountability informed by dualist Vedic philosophy, then it is important to define which Vedic texts are being considered. This thesis makes allusion to the four original Vedic texts, the Rig-veda, Yajurveda, Sama-veda and Atharva-veda, and also includes reference to the Puranas and Itihasas. The Puranas and Itihasas are Vedic commentaries on historical events and are termed by the Chandogya Upanisad as "the Fifth Veda" (Chandogya Upanisad, 7.1.4, quoted in Devamrita Svami, 2002, p. 37). Their authority is affirmed with specific citations from the four Vedas and the Upanisads. ${ }^{5}$

This thesis will refer especially to the Bhagavad-Gìtā because it contains the essence of all Vedic knowledge (Rosen, 2006), and the Bhāgavata Purāna, "the most popular of the Puranas" (Mahadevan, 1954), also known as the Śrimad-Bhāgavatam. The Bhagavad-Gìtā is a philosophical discourse that took place immediately before the Battle of Kuruksetra, fifty centuries ago, in which the sons of the King Dhrtarāstra opposed their cousins, the Pāndava brothers. A leader of the Pandavas, Arjuna, upon feeling compassion for his countrymen and kinsmen whom he would soon have to fight, decided that it would be better to

5 The Atharva-veda, for example, states:

"The Rig, Sama, Yajur and Atharva-vedas manifested from the Supreme Lord along with the Puranas" (Atharva-veda, 11.7.24, quoted in Devamrita Svami, 2002, p. 37).

The Brihad-aranyaka Upanisad (2.4.10) also makes a similar statement:

"Just as a fire kindeled with wet fuel sends out clouds of smoke, so the Supreme God has breathed out the Rig-veda, the Yajur-veda, Sama-veda, Atharva-veda, Itihasa, Puranas, science of knowledge, mystic Upansads, succinct verses, codes elaborations and commentaries. He, indeed, breaths all these out" (Brihad-aranyaka Upanisad, 2.4.10, quoted in Devamrita Svami, 2002, p. $37)$. 
leave the field before the battle commenced. Arjuna, however, takes guidance from his charioteer, Whom the Gìta states is none other than bhagavān - the Supreme Person Himself. Their conversation forms the Bhagavad-Gītā, which, in English, means Song of God. As a chapter of the Mahābhärata, which is one of the Itihasas, the Gìtā is a part of the Fifth Veda.

Krishna-Dvaipāyana Vyāsa first put the Bhāgavata Purāna, or the Śrimad-Bhāgavatam, into writing approximately five thousand years ago, and it is therefore the natural commentary on the Vedānta-sūtra. Vedānta-sütra, in English, means the conclusion of all Vedic knowledge and the ŚrimadBhāgavatam is the natural commentary on this because Vyāsa also compiled the Vedānta-sūtra. Thus the Śrimad-Bhāgavatam is authoritative because it is the natural commentary on the conclusion of all the Vedas. ${ }^{6}$ Structured like a novel, the Bhägavatam tells of the world's history and gives accounts of the extraordinary activities of ancient Vedic kings and sages to illustrate Vedic codes of ethical and moral standards. This thesis will occasionally cite passages from the Bhägavatam to illustrate principles relevant to a dualist Vedic theory of accountability.

According to the Vedas, their origins extremely ancient. Chakraborty and Chakraborty (2007), for example, state that the Rig-Veda was recorded at least 3000 BCE, making it the oldest sacred text in the world, and Saravanamuthu (2006) holds that the Vedas have been traced back to at least 5000 BCE. Generally in modern academia, however, it is considered that the beginnings of Vedic culture were sometime during 1,500 to 1,200 BCE, when Indo-Aryan tribes supposedly either invaded or migrated into the Indian subcontinent. It is commonly thought that the Vedas were written sometime after that. Sihag (2007), for instance, states that both Kautilya's Arthaśāstra and the Mahābhārata were written during the second century BCE, and therefore he states that this period may be described as India's Renaissance.

Recent satellite evidence, however, has enabled the more recent dates ascribed to Vedas antiquity to be ruled out. The Vedic texts frequently mention an abnormally wide river named the Sarasvati $i$ that flowed from the Himalayan

\footnotetext{
${ }^{6}$ Some non-dualist scholars argue that Vyāsa did not compile the Śrimad-Bhāgavatam, but that it is a modern creation written by someone named Vopadeva. However there is reference to the Bhāgavatam in the oldest of the Purānas, and therefore the Śrimad-Bhāgavatam cannot be a modern creation (Bhaktivedanta Svami, 1987, 1988).
} 
Mountains to the sea. The Sarasvatī is the principle river mentioned in the Rig$v e d a$, which contains fifty references in forty-six hymns to her. The Sarasvatî also received extensive mention throughout many Vedic texts such as the Mahābhārata, the Śrīmad-Bhāgavatam and the Padma Purāna. However, despite its frequent mention, the Sarasvatī is apparently no longer in existence. Recent satellite technology, though, has revealed the dried riverbed of the Sarasvati extending from the present Ghaggar River and flowing four miles wide in the region of India west of Delhi. Satellite and field study has determined that parts of the river began to dry up as early as $3000 \mathrm{BCE}$, and dates put its complete disappearance anywhere from 2500 to 1700 BCE (Devamrita Svami, 2002). Furthermore, archaeologists have carbon-dated dwellings constructed on the dry riverbed itself and found they are carbon-14 dated at $3000 \mathrm{BCE}$ (Francfort, 1992). Thus the Vedas, which refer extensively to the Sarasvati River, must have been written before it began to dry up, and therefore the dates suggested by Sihag (2007) that the Mahābhārata was written during the second century BCE cannot be accepted.

The small amount of literature applying Vedic philosophy to accounting and economics illustrates how Vedic principles are still relevant today, and can provide a basis for establishing ethical principles. Biswas (1998), for instance, describes that the Vedas do permit economic development and wealth accumulation, though not as ends in themselves but as means to a higher end. Sharma and Talwar (2005) relate the Vedic emphasis on charity and sacrifice for others to corporate social responsibility, and they show how these Vedic premises would serve both the long-term interests of the wider community and the organisation itself. And Saravanamuthu (2006), whose work this thesis later examines in greater detail, describes how externalities may be incorporated into a more holistic form of sustainable accounting through the interconnectedness of the entire ecosystem, which is a non-dualist Vedic premise. The Arthaśāstra, written by Chanakya Pandit around 300 BCE, describes a Vedic social structure and its systems of economics and accounting. Several accounting historians have commented on the advanced ethical qualities of Chanakya's system of accountability, and have drawn comparisons to their modern day equivalents (Matessich, 1998; Sihag, 2004, 2005). Thus, although it is thousands of years old and has generally not been significant in Western scholarship, commentators 
have nonetheless asserted that Vedic philosophy has an important contribution to make in the social and environmental literature in accounting and economics.

\section{Accountability in Religious Organisations}

Several issues are raised by a dualist Vedic theory of accountability that other commentators have addressed, and thus a brief review of the accountability literature is given here. This review is concerned with specifying a model of accountability against which dualist and non-dualist theories may be evaluated in later chapters. The matter of the sacred secular divide is then addressed in the subsequent section.

As mentioned in Chapter One, Roberts and Scapens defined accountability as the "giving and demanding of reasons for conduct" (1985, p. 447). ${ }^{7}$ Investigating the differences between Eastern and Western theories of management and accountability, Velayutham and Perera (1996) found that the specific conduct to be accounted for will depend upon a society's metaphysical conception of the self. As Roberts (1991) and others (Hines, 1988, 1989; Shearer, 2002) have described, though, the act of being held to account also constructs and sharpens one's sense of self and one's actions. Hines (1988), for instance, explains that by selecting and reflecting only the materialist aspects of society, mainstream accounting effectively confines social consciousness to the materialist universe. Roberts similarly observes that "different forms of accountability produce very different senses of our self and our relation to others" (1991, p. 385). He suggests two forms of accountability that give different senses of the self that are relevant to this thesis: hierarchical and socialising.

Roberts describes hierarchical forms of accountability, drawing on Foucault's (1979) conception of disciplinary power, as those that give an individualising sense of self. Through institutionalised and invisible channels of disciplinary power, they create in those held accountable a mental absorption with the self and with how one is seen. Roberts (1991) suggests that alongside the individualism that hierarchical accountability produces, other possible

\footnotetext{
${ }^{7}$ Others have given similar definitions, such as Arrington and Francis (1993), who observe that accountability constitutes the economic subject as answerable - obligated to demonstrate the reasonableness of their actions to a community of others through the activity of giving accounts.
} 
experiences of accountability are alive and flourishing that can produce a more rationally grounded consensus. These socialising forms of accountability also aim at confirming the self, but at the same time they openly acknowledge the interdependence of the self and the other. Socialising forms of accountability, Roberts (1991) claims, are characterised by a relative absence of asymmetries of power and are most effectively conducted in a face-to-face negotiation of significant organisational events. In contrast to hierarchical forms, socialising forms give rise to the unguarded flow of talk that draws one into a deeper and richer form of mutual engagement and reciprocal recognition. The result is a humanised experience of work where there is mutual understanding, consensus and acknowledgement of other.

Laughlin (1996) elaborates on Roberts' descriptions of hierarchical and socialising accountability by suggesting that an organisation's style of accountability will depend upon the contextual relationship between the principals and agents of that organisation. Laughlin has similar terms for Robert's forms of accountability -hierarchical accountability he calls contractual accountability, and socialising forms are termed communal accountability. Communal accountability occurs only in less formal relationships, where expectations over conduct and information demand and supply are less structured and defined. Contractual forms, on the other hand, exist in more formal relationships where expectations of action and information demand and supply are tightly defined and clearly specified. Laughlin's explanation elaborates on specific contextual situations and attributes their differences to the potential for trust and value conflict between principals and agents. Where there is a high level of trust between parties the agent will fulfil the expectations of the principal, sophisticated and formal controls are not seen as so necessary. Where there is a low level of trust, the principal will take greater pains to exert control over the behaviour of the agent - which may lead to the use of more formal and contractual mechanisms for control by the principal. A similar scenario unfolds with reference to the potential for value conflict - where there is little potential, accountability is likely to be more communal, and where there is high potential, the principal is likely to employ more contractual forms of accountability.

Such models illustrate the conventional notions of accountability dominant in economic theory and in law. Laughlin (1996) states that in both of 
these disciplines it is considered unproblematic for the principal to make certain demands over the conduct of the agent because the principal has transferred the ownership of certain resources to that agent. Thus it may be said that in the conventional framework of accountability, if the use of resources is transferred to the agent, then the agent should meet the expectations of the principal, and the principal has the right to demand from them the reasons for actions taken. Implicit to this conventional notion of principal-agent accountability is the presumption of neoclassical economics that the collective societal good is best achieved by the pursuit of individual interests. Benston (1992), for example, who adopts this outlook, implies that only to the extent that incomplete ownership rights and market imperfections exist, will shareholder interests not serve the greater good. Thus the conventional view holds that in an ideal market situation, there are no supra-contractual obligations to be recognised on that part of the agents.

Laughlin (1996), however, questions this seemingly natural and fundamental right for principals to expect compliance from the agents. He describes specific circumstances where the rights and interests of economic principles should be overridden by the expectations and requirements of what he refers to as higher principals. In certain "caring professions", Laughlin explains, there are higher principals who have hierarchical authority over the typical principal-agent relationship (1996, p. 233). Laughlin states that this is characteristic of religious organisations, where the relationship that the agent has with the divine higher principal is typecast as sacred and the relationship with the mundane principal is classified as secular or profane. He states:

“... it is assumed that certain individuals (for our purposes the 'agent') have a clear view about what is important and central in the way of values and activities (which can by typecast as 'sacred') as well as what is treated as unimportant and peripheral (the 'secular' or the 'profane'). Where what is deemed as 'secular' attempts to infiltrate, colonize or control the 'sacred', then this 'secularization process' must be resisted to prevent the sacred being compromised and perhaps obliterated" (1996, p. 232). 
Laughlin asserts that it is not only in religious organisations where the hierarchical authority of higher principals can be applied, for in other caring professions, such as education, healthcare and other social services, there is the same underlying logic that the expectations of the resource-supplying principals will clash with the requirements and values of the agents. While such accountability may be relevant to other institutions of the caring professions, Laughlin (1996) gives an empirical analysis of the Church of England in order to demonstrate this. He identifies three different levels of principal-agent relationships where resources are provided for use (the parish levels, diocesan levels and the central levels). One finding that emerged was that all of the expectations attached to the transfer of resources to the agents were very illdefined by the principals. Accountability in the Church, Laughlin states, was communal, and reporting was ex-post and was directed only to issues concerning probity and legality. In all cases, agents were left to define their activities without explicit direction from the principals. In higher levels of the principal-agent relationship, principals were seen to provide administrative machinery for the unconditional provision of an adequate resource base for the work of the agents. Furthermore, Laughlin observed that there were intermediaries who would act as buffers between principals and agents, so as to prevent the former from affecting the latter's conduct. While principals might have exerted some short-term pressures on agents regarding the use of resources, Laughlin states that in the final analysis they were seen to share the philosophy that agents should be protected from too much intrusion through making them more accountable:

“... money passes between these bodes in the Church of England with little in the way of formal controls or expectations. It is an organisation where 'high trust' dominates and, despite much current murmuring coming from questionable financial investments by the Church Commissioners, is unlikely to change in the foreseeable future" (1996, p. 235).

Agents in the Church of England could be entrusted with resources with few constraints over their actions because the entire organisation is familiar with the underlying philosophy that the agents need the "space and time" to discover the "will of God" (Laughlin, 1996, p. 236). As Laughlin describes: 
"The absence of formal controls is made possible by all participants in the Church of England being aware of the underlying values which guide its working. The Church of England is founded on 'sacred and secular' principals. It has a clear hierarchical view about what is important and central and what is more secondary. It is the foundational example of Eliade's model of sacristy. God is the 'principal', to those who adhere to this value system, before whom all participants must look for guidance and direction. Institutionally this includes setting aside certain individuals (primarily the clergy) to be the mediators for understanding the wishes of God. They need to be free - 'autonomous' using professional jargon - to perform the function in the way that they deem appropriate" (1996, p. 235).

Under more contractual forms of accountability, the agents within the Church of England would have been hampered in their work because the principals did not possess the knowledge required to discover the will of God, or they might have held conflicting interests - thus accountability in the Church was communal. Outside of the Church's example, though, there are situations where agents within organisations are held accountable to a higher principal through the use of accountability that is more contractual in nature. Islamic accountability, described in greater detail in later chapters, is one instance of this. Here it will suffice to say that such accountability is often contractual in nature, for in Islam, it is not simply religious organisations and caring professions that are held accountable to higher principals, but all organisations. Many Islamic commentators confirm this:

"Accountability to God and the notion of people having an account book with God are central tenets and presumptions of Islam ... Several commentators indeed stress that there is a strong emphasis on accountability in Islam (Omar Naseef, 1998; Lewis, 2001; Maali et al., 2003)" (Kamla, Gallhofer and Haslam, 2006, p. 257).

It was seen from Laughlin's (1996) empirical analysis of the Church of England that within caring professions, agents have a special interest and specific knowledge of how to satisfy the higher principal; and thus they are given more 
freedom in the use of resources. Islamic accountability, however, is not limited solely to the caring professions, but is applicable to all Muslims and is used to ensure that Islamic injunctions are complied with by commercial organisations. It is not assumed that all agents of the private sector are endowed with the specific knowledge of how to satisfy God, the higher principal, and nor is it assumed that they will all act simply with that intent. As Kamla et al. state:

"In point of principle, it would be reasonable to suggest at least that to the extent Islam comes to terms with capitalism it places little or no emphasis on the maximisation of profit (or shareholder wealth) - and specifically sees greed or tamma as a negative value to be avoided, while moderation (iqtisad) is seen as a positive value (Lewis, 2001, p. 108; see Rahman, 1994) - and substantive emphasis on the need to satisfy constraints reflective of Islamic principles in the context of any profit orientation" (2006, p. 253).

The specifics of such contractual accountability are not delineated in the same fashion, though, as in the conventional accountability relationship that exists solely between the principal and the agent. As Lewis (2001) describes, specific boards well versed in the injunctions of the Quran and the Sharia decide the requirements of Islamic banking and accountability. This contractual feature of accountability is to ensure compliance with Islamic injunctions by agents who are not proficient in such matters.

Islamic accountability advocates that agents outside of religious organisations should have obligations extending beyond those to the immediate resource-supplying principal, and this has also been suggested in the accountability literature for non-religious business organisations. Shearer (2002), for example, states that to achieve an ethically adequate accountability of economic entities, systems of account must be more responsive to the other. ${ }^{8}$ Shearer describes that when economic entities render accounts of themselves in economic terms, the obligations of the entity with respect to the broader community depend upon the specific conceptions of subjectivity and

\footnotetext{
${ }^{8}$ Other authors have also suggested, in various ways, that economic entities have a supracontractual obligation to some community of others. See, for example, Cooper (1992), Gray (1992), Henderson (1991), Gallhofer and Haslam (1996, 1997), Lehman (1995, 1999), Lovell (1995), Schweiker (1993) and Tinker, Lehman and Neimark (1991).
} 
intersubjectivity instantiated by economic discourse of neoclassical economics and its theory of individual choice. Therein it is held that the value of an object does not reside in the good itself, but rather in that good's relationship to the satisfaction of human desire. Thus, in neoclassical economics, the value of an object is determined by the desire of the economic subject. At this point, Shearer (2002) claims that to desire the other for the fulfillment of what is lacking in one's own subjectivity is to turn the other to one's own purposes - essentially making the other an object of satisfaction in relation to the desiring self. Hence neoclassical economics holds that all value, even the value of supposedly selfless behavior, is governed by self-interest. This, Shearer states, restricts how subjectivity and intersubjectivity are experienced and, thus, also restricts the scope of the economic entity's responsibility.

Furthermore, within neoclassical economics it is held that self-interested behaviour, owing to the theory of the invisible hand, produces the greatest common good. Within economic discourse, then, 'ethical' behavior is simply that which, while it benefits others, ultimately yields a net long-term benefit to the individual engaged in the behavior. Consequently, within economic discourse, each individual is properly held accountable only for the pursuit of his own private good (Shearer, 2002). Following Schweiker (1993), Shearer states that to hold economic actors accountable in exclusively self-interested terms contradicts the moral identity enacted in the practice of giving an account. The latter will ideally render the agent accountable to some moral community whose values and beliefs will serve to judge his intentions, actions and outcomes. On these grounds, and the basis of globally increasing social and environmental degradation, Shearer advocates that systems of accountability not limited to those in the caring professions must be made more responsive to the other.

Thus it has been seen that, for several reasons, agents have obligations to those other than the resource-providing principal. In the Church of England, Laughlin (1996) showed that accountability to higher principals overrode obligations to the mundane principal but, due to the specific knowledge of the agents, accountability was structured as communal. Islamic accountability demonstrated how the principal-agent accountability could be contractual, even when obligations to a higher principal were recognised, and Shearer (2002) has argued that to fulfill the moral identity enacted in the practice of giving an 
account, economic entities must be made accountable to a wider community of others than is currently possible under the neoclassical economic model, where one is held accountable only for self-interested behavior. These models will be used in later chapters to evaluate the dualist and non-dualist theories of sustainable accountability.

\section{Vedic Philosophy and the Sacred Secular Divide}

As explained in the first chapter, Vedic philosophy can be divided into two factions - the dualists and the non-dualists. The Vedic school used to represent dualist philosophy in this thesis is the Gaudiya-Vaisnava school, though this does not represent a pure dualist opinion. A pure non-dualist opinion is one of monism, where God, living entities and matter are all regarded as one, and any apparent difference or individuality is held to be a product of avidya, ignorance, or maya, illusion (Bhaskar, 2000). A pure dualist opinion, on the other hand, is where God, living entities and matter are regarded as completely separate from one another. Pure dualism is found in strands of Christian philosophy, where man is sometimes regarded as being unable to know God while in material existence. As McKernan and Kosmala, writing from the Christian perspective, state:

"We accept that religious belief is generally not open to conformation or refutation through empirical evidence, the kind of evidence that can command intersubjective agreement in science, and we celebrate its withdrawal from what Rorty (2005, p. 36) calls the "epistemic arena"” (2007, p. 729).

A particular religion's classification as dualist or non-dualist will determine its position on what is known in accounting and religious circles as the sacred secular divide. Within the literature on accounting and religion, there has been considerable discussion of the supposedly secular practice of accounting in the sacred mission of churches and religious institutions. Commentators have termed this debate the sacred secular divide. It has been seen that different religions offer a range of opinions on whether accounting is a secular practice or not. Some consider that when it is engaged for a spiritual purpose, the activity of accounting itself becomes sacred. Occasionally, even within the same religion, there are contradicting perspectives. Amongst Christian commentators, for instance, the 
sacred secular divide has been seen as an absolute standard governing all religious organisations (Laughlin, 1988); as non-existent (Irvine, 2005); and continuum rather than a set of absolute and opposing poles (Jacobs, 2005). Islamic opinions are less divided, with virtually all commentators claiming that Islamic injunctions govern both the sacred and secular aspects of life, and therefore they hold no barrier to accounting executing a sacred purpose (Kamla et al., 2006; Lewis, 2001; Pomeranz, 1997). The Vedas offer a unique understanding and contribution because they hold that how a religious philosophy sees the secular in relation to the divine will depend upon its location on the dualist and non-dualist spectrum. This section will thus consider the divide in the light of Vedic philosophy and describe the Gaudiya-Vaisnava position with respect to accounting and other secular activities.

The notion of a division between the sacred and secular activities of a religious organisation was introduced into the accounting literature through Laughlin's (1988) seminal study of the Church of England, where he suggested that accounting embodies a secular aspect contrary to the sacred values and orientation of religious organisations. Laughlin has maintained this suggestion in further studies (Laughlin, 1990), and other commentators have adopted this line of thought (Booth, 1993; Lightbody, 2000). The contrary has been proposed as well, though, with Kreander, McPhail and Molyneaux (2004), for instance, suggesting that because accounting cannot but be saturated with moral values (Arrington and Francis, 1993), it may be infused with theological values too. Others have made similar assertions (Faircloth, 1988; Irvine, 2005; Jacobs and Walker, 2004; Swanson and Gardner, 1986). While these opinions of the sacred secular divide represent polar opposites, Jacobs (2005) has suggested that the sacred and profane are better understood as two extreme points along a spectrum of possible experience rather than as binary conditions.

As explained, non-dualist philosophy claims that everything is one, and thus there is no difference between God and living entities. The perception of any such difference, Bhaskar (2000) states, is the product of maya, illusion, and avidya, ignorance. The pure dualist position, on the other hand, holds that God, the living entities and matter are fundamentally different. The sacred secular divide, then, is a product of thinking aligned with pure dualist thought - that the sacred and the secular are fundamentally different and the secular cannot be 
dovetailed in the service of the divine. This is evident in Laughlin's (1988) references to Durkheim (1976) when claiming that accounting used in the Church of England to evaluate and determine behaviour was seen as "an unhealthy intrusion" (1988, p. 23). When Church commissioners did use accounting information, it was used more for accountability than decisionmaking. Laughlin thus concludes that accounting systems could be legitimate aids for resourcing activities of the Church but otherwise could not be a part of the Church's sacred agenda, "and should not interfere with the more important spiritual endeavours of the Church of England" (Laughlin, 1988, p. 38). Drawing on Durkheim (1976), Laughlin presented this sacred secular divide as universal to all religions:

\begin{abstract}
"All known religious beliefs, whether simple or complex, present one common characteristic: they presume a classification of all the things, real or ideal, of which men think, into two distinct terms which are translated well enough by the words profane and sacred... This division of the world into two domains, one containing all that is sacred, the other all that is profane, is the distinctive trait of all religious thought" (Durkheim, 1976, p. 37, quoted in Laughlin, 1988, p. 24).
\end{abstract}

From Laughlin's analysis (1988), then, it is evident that notions of the sacred secular divide spring from a close alignment with pure dualist thought, where there is a clear distinction between God, living entities and matter. In more pure forms of dualism, secular activities such as accounting are generally not regarded as compatible with the sacred, as Jacobs explains:

"This sacred-secular dualism, the case that the secular is secondary, while the sacred is dominant and the perception that accounting will necessarily form part of the secular, underlie Booth's (1993) research framework. While Booth (1993, p. 58) acknowledged that the "sacred cannot be completely separated from the secular" and that the "... role of religious beliefs within the framework... is not proposed as a simple deterministic casual factor", this is in-effect what has happened. While the possibility of the alternative is present in both Laughlin $(1988,1990)$ and Booth (1993) it is too easy to read an a priori structuralist dualism. The world is divided into two parts, the sacred and the secular. We 
know that accounting is part of the secular and the "legitimate" part of the Church is part of the sacred. Therefore, the research agenda is to work out how this sacred-secular divide operates in Churches and religious organisations" (2005, p. 191).

While recognising the contributions of Laughlin and Booth, Jacobs (2005) showed in his investigations of the Church of Scotland that not all Christianity is representative of pure dualism. Jacobs refers to the writings of John Wesley, who encouraged Christians to develop personal accountability to gain all they could, save all they could, and give all they could to God - effectively using personal accountability for a sacred purpose (Wesley, 1956). Other Christian commentators have also documented the use of accounting for sacred purposes Irvine (2005) studied how a local church adopted accounting to further the church's sacred mission, and Jacobs and Walker (2004) found that Iona (Christian) community ministers used accounting systems to monitor and evaluate the use of their time and to encourage the spiritual practices of congregation members.

Jacobs (2005), then, rather than presenting the sacred secular divide as two absolute and opposite poles, drew on Studstill (2000) who saw the sacred and the secular as two extreme points along a spectrum. At the non-dualist end of this spectrum, Saravanamuthu (2006) has presented an advaitic conception of sustainable accountability based on the oneness of the entire ecosystem, which, she states, is more conducive to achieving sustainable outcomes than JudeoChristian models because it does not dichotomise humans from nature, unlike Christian models that divide the sacred and the profane. Evidently, this is the monist perspective of non-dualist thought. Within the current accounting and religion literature, then, it is possible to observe both the pure dualist and monist philosophies and their views of incorporating secular practices like accounting.

The Gaudìya-Vaisnava position on the sacred secular divide is similar to that presented by Jacobs (2005) and Studstill (2000), because it incorporates both dualist and non-dualist tenets. This is possible because Gaudiya-Vaisnavism advances the philosophy of acintya-bhedābheda-tattva: the assertion that everything is simultaneously one with and different from everything else. An ordinary, mundane perception finds it acintya - impossible to conceive how 
everything, including God, can be simultaneously one and different. Acintyabhedābheda-tattva, however, can be explained thus. The Vedas assert that God is janmādy asya yato, the source of all creation, maintenance and destruction (Bhaktivedanta Svami, 1987, verse 1.1.1). As the source of creation, all verities of energy are non-different from God. A simple example is that golden ornaments of different shapes and sizes remain non-different from the stock of gold they originated from. Similarly, the manifested universe remains nondifferent to God because He is the source of its creation. It is on this assertion that non-dualist philosophers conclude that everything is one, and that man is therefore God, which is the essential thesis of Bhaskar (2000) in From East to West. Gaudiya-Vaisnavism, however, states that although everything is nondifferent from God, one should not therefore conclude that the Supreme has lost His individual and personal existence. Krishna refutes this impersonalism in the Bhagavad-Gìtā, stating:

\author{
mayā tatam idam sarvam \\ jagad avyakta-mūrtinā \\ mat-sthāni sarva-bhūtāni \\ na cāham tesv avasthitah \\ na ca mat-stāni bhütāni \\ paśya me yogam aiśvaram \\ bhūta-bhrn na ca bhūta-stho \\ mamātma bhūta-bhāvanah
}

"By Me, in My unmanifested form, this entire universe is pervaded. All beings are in Me, but I am not in them. And yet everything that is created does not rest in Me. Behold My mystic opulence! Although I am the very maintainer of all living entities and although I am everywhere, I am not part of this cosmic manifestation, for My Self is the very source of creation." (Bhaktivedanta Svami, 1989, verse 9.4-5). These verses explain that by expanding His various energies, Krishna is not depleted, and thus He states that although $\mathrm{He}$ is present everywhere in His unmanifested form, He still remains aloof. This is simultaneous oneness and non-difference that is acintya - inconceivable to 
ordinary sense perception. A simple example is that a successful chief executive may direct many departments of a business enterprise, and thus all departments rest on his order. If someone says that the entire business rests on such a person, it does not mean that the person is maintaining all the factories and offices on his head. Nor does one expect to find the chief executive personally present in each department. Rather, it is understood that by his actions or his energetic expansion, the entire business runs without interruption. Similarly, although Krishna's energies comprise and maintain the entire universe, Krishna does not lose His individuality or personality. Bhaktivedanta Svami explains this point further:

"The Lord says that everything is resting on Him. ... This should not be misunderstood. The Lord is not directly concerned with the maintenance and sustenance of this material manifestation. Sometimes we see a picture of Atlas holding the globe on his shoulders; he seems to be very tired, holding this great earthly planet. Such an image should not be entertained in connection with Krishna's upholding this created universe. He says that although everything is resting on Him, He is aloof. The planetary systems are floating in space, and this space is the energy of the Supreme Lord. But He is different from space. He is differently situated. Therefore the Lord says, "Although they are situated on My inconceivable energy, as the Supreme Personality of Godhead I am aloof from them." This is the inconceivable opulence of the Lord" (1989, pp. 459-460).

Thus the philosophy of acintya-bhedābheda-tattva holds that God can be simultaneously one with and different from all His various energies. This philosophy has profound implications for a Vedic theory of accountability for if everything is the energy of God, then everything can be used in His service, accounting included. It also carries implications for the nature of the self, as different from matter and as a part of God, which will be described in later chapters. Thus far, though, it can be stated that by incorporating tenets of both dualism and non-dualism, Gaudīya-Vaisnavism advocates the use of the secular to serve the Supreme, just as when an iron rod is placed in a fire it will become heated and will take on the properties of fire. 


\section{Chapter Three: The Vedas and Western Scholarship}

More than a decade ago, a dialogue between accounting and the sacred would have been impossible in academia due to the over-bearing deference given to secular materialism (McPhail et al. 2004, Oslington, 2000). Therefore, the handful of papers that adopt a Vedic lens have only barely established the Vedic paradigm as a genuine body of knowledge. Saravanamuthu (2006), for instance, relates one reviewer's response to her work, in which the Gandhi-Vedic paradigm she adopts was described as "noble", but doubtful as to whether it could meet current problems of "feeding 6 billion people, providing jobs and economic development, which often brings mankind into conflict with nature" (anonymous reviewer, quoted in Saravanamuthu, 2006, p. 292). Devamrita Svami makes a similar observation:

"The Western world has known about the revolutionary contents of the Vedas for almost two centuries, but rare is the Western Indology expert who considers the texts a reasonable documentation of human civilisation. Even Indian scholars have been trained to feel apologetic or disdainful about what has come to be viewed as the Vedas' gross exaggerations and fantasies concerning the ancients. A. L. Basham, who wrote the popular classic The Wonder that Was India [1954], is one of many" (2002, p. 155).

Thus Vedic philosophy still does not receive the same consideration given to secular forms of knowledge, or even that given to other sacred forms. As described by Nathan and Ribiere (2007), Islamic banks, which derive their injunctions from Islamic scriptures, now operate in almost seventy-five countries, and the industry has a market estimated at US\$250-300 billion. As the ninth chapter will describe, much work remains to establish the Vedas as a genuine discipline of knowledge.

McPhail et al. (2004) point out that when modern and post-modern critiques of theology are applied reflexively back on themselves, the claims of science and post-modernism are shown to be no less spurious or arbitrary than those made by the world's different religions. Millbank (1990), for instance, claims that modern and post-modern critiques have often tried to undercut claims made by religions by emphasising their historical and linguistic nature. He states: 
"Theology has rightly become aware of the (absolute) degree to which it is a contingent historical construct emerging from, and reacting back upon, particular social practices conjoined with particular semiotic and figural codings" (Millbank, 1990, p. 2, quoted in Oslington, 2000, p. 34).

Millbank (1990), however, also points out that modern and post-modern social sciences are subject to the same historical and linguistic criticisms that they pitch at theology. Millbank, though, does not attempt to restore any pre-modern Christian position and he completely accepts descriptions of theology as merely historical and linguistic. This thesis, however, endeavours to establish from a critical realist position that sacred forms of knowledge should be recognised for the religious experiences that they can generate in practitioners. Recently theologians have employed critical realism to transcend the post-modern impasse. This thesis employs the critical realist philosophy of Archer et al. (2004) to establish parity between sacred and secular forms of knowledge and challenge tendencies for atheism not having to present its credentials in academia, whereas sacred forms of knowledge must. These arguments originate from Bhaskar's spiritual developments of the philosophy of critical realism, the basic tenets of which are outlined below.

\section{Critical Realism}

The term critical realism is associated with the earlier work of Roy Bhaskar. In his first book, A Realist Theory of Science, Bhaskar (1975) defended a position he called transcendental realism, which referred to the ontology derived from his analysis of scientific practices. Bhaskar explained that for science to be possible, the world must exist in a certain way, and, given how scientific training and experimentation take place, an ontological reality independent of human knowledge constructions is necessary. In 1979, Bhaskar argued for an extension of transcendental realism to the social sciences in The Possibility of Naturalism, calling its stance critical naturalism. Since then, readers have combined the two terms to produce the name critical realism. In a later publication, Dialectic: The Pulse of Freedom, Bhaskar (1993) changed the terminology to transcendental dialectical critical realism. In his latest publication, From East to West: The 
Odyssey of a Soul, Bhaskar (2000) developed his dialectic critical realism into a philosophy of universal self-realisation, claiming that it does not involve any rejection of existing critical realist positions.

Archer et als' (2004) arguments for including debates on God's existence in academic scholarship are based on Bhaskar's (1975) transcendental realism and, to a lesser extent, his latest, more spiritual developments. This section, then, concentrates on describing Bhaskar's transcendental realism. The philosophy of critical realism, however, is a "broad church" - there are many differences in thought that are disputed amongst intellectuals who might be labelled as critical realists (Potter and Lopez, 2001, p. 15). This thesis does not consider all variations of the philosophy, but seeks only to explain its fundamentals in order to underpin subsequent arguments that the Vedic teachings are a legitimate form of knowledge. The critical realist paradigm does possess some core propositions (Potter and Lopez, 2001), which this thesis describes.

In A Realist Theory of Science, Bhaskar (1975) locates transcendental realism within a general history of the Western philosophy of science. Bhaskar identifies the classical empiricist position presented by Hume as the first philosophical reference point to compare transcendental realism with. The essential characteristic of empiricism that Bhaskar identifies is that Hume considered the ultimate objects of knowledge to be atomistic events. The second broad philosophical position Bhaskar identifies is Kant's transcendental idealism. Here objects of knowledge are artificial constructs of the mind and are therefore not independent of men or human activity. According to transcendental idealism, then, the natural world is a construction of the human mind or, in some modern versions, of the scientific community.

In contrast, transcendental realism regards objects of knowledge as "structures and mechanisms that generate phenomena" (Bhaskar, 1975, p. 19) objects of knowledge are neither the phenomena nor the events that they are for empiricism; nor are they human constructs imposed upon phenomena, as suggested by idealism. Instead, they are held to be structures and causal laws that endure and operate independently of human knowledge, human experience and the conditions that allow observers access to them. In contrast to empiricism, objects of knowledge are structures, not events; in contrast to idealism, they are intransitive - independent of human activity. This explicates Bhaskar's 
transcendental as opposed to empirical realism. The entities that the transcendental realist is concerned with are the objects of scientific discovery and investigation, such as causal laws, and not the events produced by experiments (Bhaskar, 1975). For the transcendental realist, then, science is not an epiphenomenon of nature as it is with empiricism, and nor is it a product of man as according to idealism. As Philip summarises:

"The basic framework which transcendental realism sets out to establish begins by arguing that the real $i s$, the real world exists independently of our experience; our knowledge of the world is thus provided by means of experience; while for empiricists, experience contains all there is to reality - experience constitutes what is. Transcendental realism argues that experience is merely the appearance of independently existing objects - perceived objects without knowing what in fact they are. Knowledge constitutes accounts of things, structures, mechanisms etc., rendering knowledge of objects to the category of conjecture or hypothesis, that is, our knowledge of the world is rendered fallible" (1995, p. 28).

Bhaskar reaches this transcendental realist position by posing the question: what must reality be like for science to be possible? He states that it is not necessary that science occurs, but, given that it does, it is necessary that the world is a certain way (Bhaskar, 1975). Hence the transcendental realist asserts that the structured nature of the world can be established by philosophical argument:

"For it is not the fact that science occurs that gives the world a structure such that it can be known by men. Rather, it is the fact that the world has such a structure that makes science, whether or not it actually occurs, possible. That is to say, it is not the character of science that imposes a determinate pattern or order on the world; but the order of the world that, under certain conditions, makes possible the cluster of activities that we call 'science"” (Bhaskar, 1975, p. 23).

To establish this, Bhaskar (1975) argues that the intelligibility of perception and experimental activity in science both presuppose the intransitive and structured character of objects of knowledge. Bhaskar points out that the epistemic significance and very meaning of perception implies the independent existence 
of objects of knowledge. The possibility of scientific change and criticism, as well as the necessity for scientific training, takes for granted the intransitivity of real objects. As Bhaskar states, if the changing experience of objects is to be possible, then it follows that objects must have a distinct being in time and space from the experiences of which they are objects:

"For Kepler to see the rim of the earth drop away, while Tacho Brahe watches the sun rise, we must suppose that there is something that they both see (in different ways). Similarly when modern sailors refer to what ancient mariners called a sea-serpent as a school of porpoises, we must suppose that there is something which they are describing in different ways" (1975, p. 24).

If objects of knowledge are distinct from experiences of them as objects, then it can be claimed that events and momentary states do not exhaust the objects of perception, and that events are categorically independent of experiences. As Bhaskar describes, then, there could be a world of events without experiences. Given the possibility of a world without perceptions, there is no reason why there should not be events in a world containing beings capable of perception that otherwise go unperceived, and, given current human capacities and qualifications, are unperceivable. Even a superficial review of the history of science will show events never imagined, of which theoretical, and sometimes empirical, knowledge is eventually achieved (Bhaskar, 1975). These transcendental arguments form the basis for Bhaskar's (2000) more recent claims for the existence and perception of God.

Bhaskar supports his arguments for transcendental realism with an analysis of experimental activity. In empiricist ontology, a causal law is regarded as a constant conjunction of perceived events. An experiment that artificially constructs a controlled environment is necessary for such a conjunction of events, for the events would not be forthcoming without it. The theory underlying such experimentation is that by bringing about a particular conjunction of events in an artificial environment, one will find out what the world is like outside of such an environment. This belief, however, presupposes that scientists actively induce regularities, not that they produce the causes of such regularities. If experimenters were thought to produce not just regular 
conjunctions but also the laws governing these, then such laws could not be expected to hold outside of the experimental settings (Groff, 2004). Thus, as Bhaskar (1975) states, the transcendental realist holds that causal laws, instead of being the constant conjunction of events produced via experimentation, are categorically independent of that sequence of events. The scientist conducting the experiment is the causal agent of the sequence of events but not the agent of the causal law identified from the sequence of events due to the controlled conditions of the experiment. As Bhaskar describes:

"It lies within the power of every reasonably intelligent schoolboy or moderately clumsy research worker to upset the results of even the best-designed experiment, but we do not thereby suppose they have the power to overturn the laws of nature. I can quite easily affect any sequence of events designed to test say Coulomb's or Guy-Lussac's law; but I have no more power over the relationships the laws describe than the men who discovered them had. In short, laws cannot be the regularities that constitute their empirical grounds" (1975, pp. 25-26).

Given this categorical independence of causal laws, it is possible to hold that laws continue to operate in open systems, where no constant conjunction of events prevails. This categorical independence of causal laws forms another premise upon which Bhaskar (2000) argues for the existence of God.

The intelligibility of sensory perception and experimental activity, then, both presuppose the intransitive nature of the objects of scientific knowledge, at least as causal laws. Bhaskar (1975) declares that any adequate philosophy of science must show how science is a transitive, socially generated process, and take into account intransitive objects of knowledge that do not depend upon human activity, such as the specific gravity of mercury, the process of electrolysis and the mechanism of light propagation. As described above, Bhaskar makes this proclamation in light of his analysis of experimental activity, for based on this it is possible to argue that in a world without humans to observe the intransitive, reality would presumably continue to act and interact: 
"If men ceased to exist sound would continue to travel and heavy bodies fall to the earth in exactly the same way, though ex hypothesi there would be no one to know it ... The tides would still turn and metals conduct electricity in the way that they do without a Newton or a Drude to produce our knowledge of them... Two atoms of hydrogen would continue to combine with one atom of oxygen and in favourable circumstances osmosis would continue to occur" (Bhaskar, 1975, pp. 21-2).

Thus the transcendental realist asserts the existence of an ontological reality independent of human intervention. Transcendental realism, however, does allow for the influence of social and historical conditioning in science, which Bhaskar (1975) terms epistemic relativity. Thus, although holding to a realist ontology, critical realism allows for a subjective, transitive interpretation of the intransitive objects of knowledge that Bhaskar asserts via his analysis of experimentation. To suppose, however, that because there is no epistemologically objective view of the world, there is also no objective world ontologically, is to commit what transcendental realism terms the epistemic fallacy. This is committed when statements about intransitive objects of knowledge are regarded as equivalent to statements about the transitive, which leads to the relativist claim that to the extent that there are different worldviews, the holders of these worldviews inhabit ontologically different worlds (Groff, 2004). Potter and Lopez explain that critical realism instead exhibits epistemological caution regarding scientific knowledge, thus allowing room for subjective interpretation whilst not conflicting with realist ontology:

"Critical realism accepts most (if not all) the significant differences between the respective subject matters of social and natural science. It understands as essentially correct all the peculiarly human features of the objects of social scientific knowledge which, according to the hermeneutic tradition, renders it not susceptible to scientific explanation. It accepts that human society is much more like a language than a mechanical machine. It accepts the full significance of the manner in which theorising is socially located. It accepts the significance of the 'language-borne' nature of theory. It accepts the socially constructed nature of knowledge" (2001, p. 9). 
By acknowledging the relative nature of transitive knowledge, the goal of transcendental or critical realism becomes what is termed alethic truth. Epistemologically, all such judgements remain provisional, yet a point is reached where science will consider the case virtually settled:

"Although we remain open to new arguments should they appear, we do not expect any to turn up. Among the alethic truths that most people hold today are the roundness of the earth, the law of gravity, and the existence of microbes. It is not that absolutely everyone accepts these putative truths, but that among those who do the remaining arguments of the dissenters fail even to be intellectually challenging. Further, intellectually challenging arguments to the contrary do not even appear on the horizon. On matters such as these, those familiar with the arguments are fairly sure that they have got reality right" (Archer et al. 2004, pp. 2-3).

Because transitive accounts of reality are different accounts of one underlying reality, Bhaskar asserts that it is possible to reach alethic truths through judgmental rationality. As Potter and Lopez state, "we can (and do!) judge between competing theories on the basis of their intrinsic merits as explanations of reality. We do so both scientifically and in everyday life. If we could not we would not be very frequently successful in even our most mundane activities" (2001, p. 9). Bhaskar also states:

"If the relation between theories is one of conflict rather than merely difference [as is the case with the suggestions of Kuhn and Feyerabend that no meaning may be shared in common between a theory and its successor], this presumes that there are alternative accounts of the same world, and if one theory can explain more significant phenomena in terms of its descriptions than the other can in terms of its, then there is a rational criterion for theory choice, and $a$ fortiori a positive sense to the idea of scientific development over time. In this sort of way critical realism claims to be able to combine and reconcile ontological realism, epistemological relativism and judgemental rationality" (1998, pp. x-xi). 
These three tenets - ontological realism, epistemological relativism and judgemental rationality - form the basis of the critical realist philosophy. The next section describes how Archer et al. (2004) utilise these to argue that spiritual topics can be the subject of judgemental rationality.

Before moving on, though, it is of interest to briefly consider critical realism in the light of dualist Vedic philosophy. Dualism also holds to a realist ontology and, like critical realism, it claims that one's perception of reality is obscured due to conditioning. The Vedas recognise four main defects in the conditioned living entity's ability to perceive ontological reality: firstly, time and space constraints and social conditioning limit his sensory perception. Secondly, he is subject to making mistakes - although he may hold all the relevant data, he may simply read it incorrectly. Thirdly, the conditioned living entity is subject to illusion - the acceptance of one thing for something it is not. Finally, the Vedas describe the cheating propensity - although the subject has limited senses, makes mistakes and can be bewildered by illusion, the living entity may still put himself forward as a learned philosopher or a leader in society. As Devamrita Svami states:

"We should bear in mind that naïve realism has no value in the Vedic texts. Only a fool is said to believe the world exists directly as his senses perceive it. Because human vision feels so simple, we have the tendency to think that the image we see is directly the world "outside ourselves." ... The Vedas assume that we understand that the world as we perceive it - or think about it - depends on our states of consciousness, our levels of awareness. The texts point out that we are only dealing with appearances - the effects of something upon our consciousness. That something is - in of itself - unknown to us, because of the filtration done by our senses, combined with the meditation done by our states of consciousness" (2002, pp. 101-102).

Thus dualism, in this respect, holds to the same principle as critical realism through conventional methods, knowledge is epistemically relative. However the goal of dualism is not the alethic truth that it is for Bhaskar. Rather, the GaudiyaVaisnava philosophy holds a similar tenet as the non-dualists - God is the fundamental constituent of reality. Employing the philosophy of acintya- 
bhedābheda-tattva, though, Gaudīya-Vaisnavism also holds that God is simultaneously a person, just as a government, for example, has a personal and an impersonal aspect. Being a person, God can reveal Himself at His own discretion. As Krishna describes in the Bhagavad-Gìtāa, He is inclined to reveal himself to someone who has His interests at heart, and is therefore always prepared to serve Him. The same principle exists in a material context - one is more inclined to reveal personal aspects of himself to someone who is always concerned with his welfare. In Sanskrit, this service to God is called bhakti-yoga, which translates into English as the yoga of devotion. Concerning the epistemology of the Vedas, the Vedic scholar Rūpa Gosvāmī states:

\author{
atah śri-krisna-nāmādi \\ na bhaved grāhyam indriyaih \\ sevonmukhe hi jihvādau \\ svayam eva sphuraty adah
}

"No one can understand Krishna as He is by the blunt material senses. But He reveals Himself to the devotees, being pleased with them for their transcendental loving service to Him" (Bhakti-rasamrta-sindhu, 1.2.234, quoted in Bhaktivedanta Svami, 1989, pp. 368-369). The Sanskrit term yoga describes a union (Wilson, 1997), just as religio - the Latin root of the English word religion - means to bind. Some commentators suggest that the import of the word religion is that religion is the binding agent intended to keep members of a society functioning together harmoniously by the endorsement of slogans such as loving thy neighbour. When understood in light of the Vedic meaning of yoga, religion and religious practice are seen as intending to bind one in relationship with God through spiritual experience - the Supreme revealing Himself to the rigid practitioner. As McPhail et al. (2004) state, though, such statements have generally not been recognised in mainstream academia as credible scholarship, and therefore it is necessary to argue why the Vedas are a legitimate tradition of knowledge. This is done with reference to the critical realist arguments of Archer et al. (2004). 


\section{Critical Realism and Sacred Forms of Knowledge}

As explained, critical realism asserts that for activities called science to be possible, an underlying, ontological reality is necessary. From the vantage point of critical realism, Archer et al. (2004) argue that there must be an ontological answer to the question of God's existence. Just as Bhaskar's analysis of experimentation demonstrated the necessity of an underlying ontological reality, Archer et al. similarly assert that documented cases of spiritual experience give evidence for an underlying spiritual reality. They state:

"So many [religious experiences] from so many different cultures all independently report some experience of transcendental reality. Is there not some reality behind it all? Can all be similarly mistaken about the category of the transcendent and are all just mistaking group consciousness for divine? There are no simple answers, but this observation, too, carries its own power" (Archer et al., 2004, p. 12).

Appealing to the experience of a transcendental reality, the "faith in the possibility of the impossible," that McKernan and Kosmala (2007, p. 742) espouse is not adopted by Archer et al. to justify the inclusion of sacred knowledge in academia. Nor do the Vedas appeal to such notions. Instead the transcendental experience generated by the practice of Vedic philosophy is put forward as evidence that it should be seriously considered in academic scholarship. Since differing experiences are an entry point to rational debate, Archer et al. hold that the question of God's existence is amenable to judgemental rationality, and thus better or worse arguments for God's ontological reality can (and should, they state) be proposed and evaluated within academia.

The Vedic literatures describe a process by which one can obtain spiritual, or transcendental experience and, if one's determination is firmly fixed, how one can become eligible for God-realisation. This is confirmed by Krishna in the Bhagavad-Gìtā:

vita-rāga-bhaya-krodhā

man-mayā mām upāśritāh 


\title{
bahavo jūāna-tapasā
}

pūtā mad-bhāvam āgatāh

\begin{abstract}
"Being freed from attachment, fear and anger, being fully absorbed in Me and taking refuge in Me, many, many persons in the past become purified by knowledge of $\mathrm{Me}$ - and thus they all attained transcendental love for $\mathrm{Me}$ " (Bhaktivedanta Svami, 1989, verse 4.10). Here, Krishna states that in the past many people, equipped with the necessary qualifications, have become God realised and have thus attained transcendental experience of the Supreme. The non-dualist schools of thought have also asserted that the Vedas give a process for attaining transcendental experience:
\end{abstract}

"The practical value of the Vedic Science is that it includes techniques for
experiencing and thereby developing the full range of consciousness in the
individual. The key element here is the experience of the simplest, most settled
state of human awareness, termed "transcendental consciousness"” (Druhl, et
al., 2001, p. 392).

Similarly, Inayatullah (2005) refers to the documented psychological benefits of meditation and has suggested that such measures can serve as a basis for spirituality to become a fourth bottom-line in annual reports, as its benefits can now be empirically verified. Elsewhere, certain Vedic meditative practices are being promoted as a managerial tool to improve employee effectiveness (Heaton and Harung, 1999), and consciousness is being suggested as a common ground for theories of organisational change (Druhl et al., 2001). Thus the Vedic paradigm is not a discipline of faith but is one of experience. As Wilson states, writing from the Vedic worldview, "Spiritual development can take place with or without adherence to specific religious beliefs" (1997, p. 520). Because Archer et al.'s (2004) arguments hinge upon transcendental experience, they apply especially to the Vedic tradition.

The previous section described how, in critical realism, individual experiences would be varied, or epistemically relative, due to the socially conditioned nature of transitive knowledge. As Bhaskar (1975) observed, though, differing accounts of experience must be alternative accounts of the same 
ontological reality, otherwise science itself would not be possible. Potter and Lopez (2001) therefore state that post-modern philosophies that ascribe to relativism cannot adequately explain why science continues to produce useful knowledge. As the previous section explained, differing accounts of the same reality may be evaluated through judgemental rationality. Thus, according to Archer et al. (2004), the variegated accounts of spiritual experience provide an entry point to rational debate, for all such debates are initiated by differing standpoints of experience. They state:

"Our theories differ, in part, because our experiences differ. Our different experiences, however, are not the end of the story. They do not remain impervious to adjudication and correction. Instead we come together in conversation to reason about them" (Archer et al., 2004, p. 5).

Thus Archer et al. argue that debates about the existence of God should be accepted in academia on the basis of religious experience. This thesis adds to this by asserting that sacred forms of knowledge such as the Vedas - because they describe methods capable of producing transcendental experience - should be accepted in academic debate, and be considered as informing bodies of knowledge in disciplines like economics and accounting.

While Archer et al. (2004) suggested that widespread transcendental experience is evidence of an underlying spiritual reality, other commentators point out that such variegated experiences may instead indicate the absence of any such reality, because no one religion's explanation of God and reality can account for all such experiences (Collier, 2004). Archer et al. admit to this as well:

"There is the feeling of creature consciousness identified by Friedrich Schleiermacher; the experience of the numinous or holy as identified by Rudolf Otto; the sense of the transcendent as expressed by Martin Buber; and the experience of self-engulfment and cosmic union described by the Western mystical tradition but particularly associated with the Eastern religions" (2004, p. 12). 
Thus, while they hold that purported spiritual experiences are the sign of an underlying transcendental reality, Archer et al. nonetheless admit that their verity represents a potential hurdle for all religions - each of which proposes to explain God's existence. Variegated transcendental experience, however, does not interfere with the Vedic description of the Supreme, which encompasses different experiences based on one's dedication and practice of God-realisation. To this end the Śrimad-Bhāgavatam explains:

\author{
vadanti tat tattva-vidas \\ tattvam yaj jūānam advayam \\ brahmeti paramātmeti \\ bhagavān iti śabdyate
}

"Learned transcendentalists who know the Absolute Truth call this non-dual substance Brahman, Paramatma or Bhagavan" (Bhaktivedanta Svami, 1987, verse 1.2.11). Hence the Vedas hold that although different realisations of God are possible, such as personal or impersonal, the transcendentalist with full realisation knows there is no qualitative difference between them. ${ }^{9}$ Furthermore, in the Bhagavad-Gìtā, Krishna states, ye yathā mām prapadyante tāms tathaiva bhajāmy aham: "As all surrender unto Me, I reward them accordingly" (Bhaktivedanta Svami, 1989, verse 4.11). Thus the Vedic literatures allow for different realisations of the same God depending on one's desire and practice. Therefore different experiences of the same transcendental reality are not an impediment to accepting the Vedas in rational debate.

However, even prior to considering differing experiences of transcendence, it is possible to question such experiences altogether, alleging that critical realism holds them to be epistemically relative, and therefore products of social conditioning. An advocate of this theory might assert that because someone has been socially conditioned to believe in God, they will imagine for

\footnotetext{
${ }^{9}$ Bhaktivedanta Svami explains the purport to this verse, stating, "The same substance is realised as impersonal Brahman by the students of the Upanisads, as localised Paramatma by the yogis, and as Bhagavan [the Personality of Godhead] by the devotees... Less intelligent students of either of the above schools sometimes argue in favour of their own respective realisation, but those who are perfect seers of the Absolute Truth know well that the above three features of the one Absolute Truth are different perspective views seen from different angles of vision" (Bhaktivedanta Svami, 1987, First canto, pp. 103-104).
} 
themselves the experience of transcendence. However, as is explained below, critical realism does not attribute all factors that influence a person's beliefs exclusively to social conditioning. Room is also allowed for the experience of reality. Furthermore, epistemic relativism is not limited just to religious experience but extends also to the experiences of atheists and agnostics. Their absence of religious experience is itself a kind of experience, also subject to prevailing norms, circumstances and conceptual schemes, and factors of personal biography such as resistances, prejudices and preferences. Archer et al. therefore state that the purported experience of the absence of transcendence "is no less corrigible than the experience of presence" (2004, p. 4). Porpora elaborates on this:

\footnotetext{
"Religious nonbelief stands in as much need of explanation as religious belief. It is only a lingering bias of the Enlightenment that makes the intellectual baseline and belief, alone, something to be explained. Treating belief and nonbelief symmetrically, the distinguishing generative mechanism is religious experience. ... Thus, although atheists and agnostics may think that they, at least, are examining the objective evidence dispassionately, they tend to forget that what they are also entering into evidence is their own absence of religious experience" (2000, p. 14).
}

Thus the critical realist position holds that there is an ontological answer to the question of God's existence, but given that experiences are subject to interpretation affected by historical and social conditioning, experiences of that reality will vary. Atheistic beliefs are not exempt from social conditioning, and therefore it cannot be held that religious belief is something to be explained and atheism is not. Because of the claim to transcendental experience Archer et al. (2004) hold that the question of God's existence is permissible in judgemental rationality. The same applies to sacred forms of knowledge - it cannot be held that they are unacceptable in rational debate when they can produce transcendental experience that may be the subject of judgemental rationality.

Although transcendental experiences are a widely acclaimed phenomenon, the social sciences have nonetheless privileged atheism and presented it as an epistemologically neutral position, instead of what Archer et al. 
(2004) describe as - a commitment to a belief in the absence of religious phenomena. Beed and Beed (2004), for instance, state that most economists and social scientists avoid presenting religious beliefs in their professional work, one reason being that they believe that they are following a science from which metaphysical presuppositions and values should be banished. To account for this, Archer (2004) explains that since the Enlightenment, the social sciences have adopted certain models of man that systematically preclude the human subject from having transcendental relations, and thus they have attributed religious faith and belief exclusively to social causes. She argues that such models are defective for both the social sciences and disciplines of faith because they assume that all of man's relationships with reality are socially derived. The critical realist model that she suggests, though, does allow for an ontological reality determining an individual's nature and beliefs, and thus it does not rule out in advance the possibility of authentic human relations with the divine (Archer, 2004).

Since the Enlightenment, Archer et al. (2004) explain, two models of the human being have dominated social theorising: the instrumentally rational Homo Economicus of positivist thought, whom Archer refers to as Modernity's Man; and the product of social constructionism - Homo Sociologicus - who Archer denotes as Society's Being. The former stresses human self-sufficiency, whilst the latter emphasises social dependency. To examine the personal qualities of Modernity's Man first, one may observe that, in essence, he is simply an instrumentally rational and calculating seeker of preference satisfaction. Theories of markets and collective choice in neoclassical economics and the political domains where Homo Economicus was born take individual preferences as given. As Hahn and Hollis (1979) explain, neo-classical economics is characterised by an overriding concern with the individual, conceived in isolation from the social, political and economic institutions in which he exists. Weale also explains, "no attention is paid to the source of these preferences, or to the extent to which they may be modified in the light of reflection and argument" (1992, p. 63). Free from any embedding in historical circumstances, then, Homo Economicus is a model that strips the human being down to one remaining property - the capacity to maximise his preferences through means-ends relationships to optimise his utility. Natural, social and transcendental relationships are not even partially constitutive of the beliefs he holds, and 
although man works on the world, the world does not work on him - except by attaching risks and costs to the accomplishment of his pre-formed designs. As Daniels states:

\begin{abstract}
"Convinced of the objectivity and value-free stance of their discipline, economists adopted secular, rational economic man as the archetypical behavioural model of economic decision-making. Individual welfare was considered simply as a positive function of consumption derived from accumulation of material wealth. There was minimal recognition of the dynamic nature and importance of the underlying beliefs and values which may structure or at least heavily influence human behaviour" (1998, p. 968).
\end{abstract}

Therefore Homo Economicus is closed against any experience of reality that could make him fundamentally different from what he already is, and thus the modern self has been ontologically purged of transcendence (Archer, 2004). As Philip describes:

"To reduce the understanding of human action to the terms of purely physical laws is to ignore those very distinguishing features of humans - speech, reason and spirituality" (1995, p. 22).

While Modernism's self has been immunised against all outside influence, social constructionism takes the other extreme and presents all human properties beyond biological constitutions - as the gift of society, beliefs included. Social constructionism therefore precludes the role that religious experience plays in determining beliefs by assuming that man is nothing beyond what society has made him through his participation in society's conversation. Weale explains:

"Homo sociologicus lives according to rules, roles and relations. As Homo sociologicus grows up, he must undergo rites of passage in relations from boyhood to manhood, having been socialised into the appropriate norms of behaviour. At work he will need to adjust to the division of labour, and when he falls ill he does not simply suffer physical malfunction but adopts the sick role. Politically he adopts the attitudes appropriate to someone with his education, occupation, social status and place of abode" (1992, p. 63). 
The same is so for Homo Sociologicus when it comes to his choice of faith. According to post-modern thought, his religious belief is nothing more than a product of social conditioning and evidence of transcendental experience is not recognised as the experience of reality (Archer, 2004). This is evident in McKernan and Kosmala (2007), who, adopting the constructionist position, state that the disciplines of religion and accounting now operate in environments that are effectively post-modern:

"We are inclined to see science, religion, and for that matter accounting as language games, each in their own way grounded in faith, each having reasons for the claims they make, and each having lost any meta-narrative grounding, or legitimation, it might have once had" (2007, p. 731).

A partiality can also be observed, for many founding fathers of the social sciences - Durkheim, Freud, Marx, Nietzsche and Weber, who Collier refers to as the "Masters of Suspicion" (2004, p. 82) - all give debunking explanations of the prevalence of religion. Marx famously referred to religion as the opium of the people, and Weber declared himself religiously unmusical. Their critiques, however, are debunking in the sense that religions console people and play on their unhappy lot by the power of wishful thinking, but they are not explanatory critiques that show a religion's truth claims are false. At most they show that religious belief is produced by an oppressive social structure (Collier, 2004).

Collier points out that all the Masters of Suspicion; Marx, Freud and Nietzsche, are materialists, and therefore, "more or less take it for granted that religion is false, the only question being why a false belief became so widespread" (2004, p. 83). He adds that none of them consider that secularism could be subjected to a similar critique, and they all assume that secular knowledge is obvious, and confer upon themselves the authority to place the onus on religion to prove its contentions. The secularist claims that one needs reasons for believing in something but not reasons for not believing something. However, the secularist has not the non-belief of religious phenomena but a belief in their absence, and, as Collier states, one needs grounds for these beliefs as much as for religious beliefs. Secularism or materialism, then, is not a neutral 
position, and the idea that religion is an extra belief beyond ordinary beliefs is not a neutral standpoint but a partisan, secularist one.

Because of the dominance of these two models of man in the social sciences, transcendental experience has been excluded from the analysis of what determines religious belief and faith in sacred forms of knowledge. The consequence is that sacred forms of knowledge are regarded as lacking in falsifiability. This is the objection that Oslington (2000) claims many economists have to Christian theology. McKernan and Kosmala (2007), for instance, who write from the post-modern standpoint, state that they do not regard religious belief as being open to empirical verification. Lack of falsifiability, or reconciliation to blind belief, is also a concern of Saravanamuthu (2006). She cites Swami Vivekananda, a famous non-dualist philosopher, who argued that religious forms of knowledge should be subjected to the same methods of investigation as scientific and secular forms of knowledge (Saravanamuthu, 2006). Vedic philosophy, however, asserts that God's existence, and therefore the authenticity of the Vedas is falsifiable - by following a particular process of engaging the mind, body and words, one may obtain transcendental experience. In the Bhagavad-Gìtā, Krishna uses two Sanskrit words to describe categories of knowledge: jūanna and vijñāna. Jñanna refers to the theoretical understanding of the knowledge in the Vedas, and vijñanna means the experiential realisation of that knowledge. As Stein (2002, p. 51) writes concerning the Vedic epistemology, "We see that one does not merely know the truth; one realises it or has a direct and immediate experience of it." Other commentators as well have attested to the falsifiability of the Vedic teachings:

"We have argued above that a complete approach to organisational change and development must include a scientific account of and approach to the subjective aspect of the organisation, represented by its individual members. By scientific we mean, in particular: systematic, rational and subject to empirical test. ... To this end, we will now consider a worldview which sees the subjective aspect of reality as most basic, and yet contains approaches for individuals and organisational development which can be empirically tested, and thus objectively verified. This view is expressed in the ancient Vedic tradition of 
knowledge, which has been residing in India since time immemorial" (Druhl et al., 2001, p. 390).

This is also the assertion of Krishna in the Bhagavad-Gìta where He explains to Arjuna that through the practice of bhakti-yoga, one will be able to see Him, just as He was standing before Arjuna at Kuruksetra:

$$
\begin{gathered}
\text { bhaktyā tv ananyayā śakya } \\
\text { aham evam-vidho 'rjuna } \\
\text { jñātum drastum ca tattvena } \\
\text { pravestum ca parantapa }
\end{gathered}
$$

"My dear Arjuna, only by undivided devotional service [bhakti-yoga] can I be understood as I am, standing before you, and can thus be seen directly. Only in this way can you enter into the mysteries on My understanding" (Bhaktivedanta Svami, 1989, verse 11.54). Thus when Swami Vivekananda asserts that religious knowledge should be subjected to the same methods of investigation as in the sciences, dualist Vedic philosophy does not protest this. In the Bhagavad-Gìtā, Krishna never tells Arjuna simply to believe in Him, rather He advises Arjuna to adopt the path of bhakti-yoga.

For bhakti-yoga to be regarded as falsifiable, though, academia must first allow for the influence of transcendental experience upon the individual. Archer (2004) shows that religious beliefs are often deemed to be false because the experiences upon which they are based are automatically discounted. Such experiences are, however, specifically what the critical realist model of man allows for. From the realist point of view, the central deficiency of Homo Economicus and Homo Sociologicus is their basic denial that the nature of reality makes any difference to the beliefs that people hold (Archer, 2004). In both versions what is lost is the direct experience of reality. Instead two versions of the epistemic fallacy, whereby reality is a consequence of modernity's instrumental rationality or society's discourse, are substituted for what the world really is. As previously explained, the epistemic fallacy is committed when the inference is made that because there is no epistemologically objective view of the world, there is also no objective world ontologically. This leads to the relativist 
claim that to the extent that there are different worldviews, holders of these worldviews inhabit ontologically different worlds:

"It implies that when people discovered that the earth revolves around the sun and changed their opinions accordingly, then the objective world they inhabited actually changed. Before, say, Galileo, the sun revolved around the earth and then suddenly did not. For better or worse, critical realists believe that the world cannot be altered just by altering our beliefs about it" (Archer et al., 2004, p. 2).

Although realists concede that all experiences are fallible, critical realism cannot accept any foreclosure that prematurely restricts that which can be experienced, and hence influences what people become (Archer, 2004). Nor can it accept religious belief simply on the grounds of blind faith either, as this does not meet the criterion of judgemental rationality:

"To make faith into blind faith, as some religious people do, is not intellectually acceptable. It is not intellectually appropriate to privilege any belief - not even a religious belief - in such a way that it becomes immune to judgemental rationality. If we feel to privilege our own pet beliefs in this way, why should not racists so privilege their racism? If, as religious believers, we are still to remain a part of the community of rational dialogue, all our beliefs, including our religious beliefs, must be equally placed upon the table" (Archer et al., 2004, p. 16).

Realism, then, allows for the possibility of unmediated human experiences that are not necessarily reducible to self-referentiality, as in Modernity's Man, or to social constructions, as in Society's Being:

"Realism opens up a space, which, of course, was never really closed, in which whatever properties and powers pertain to reality can have an unmediated influence upon us, through our experiences of them, which need not be articulated. Primitive man experienced gravity as he fell down inclines and failed to jump over large obstacles, under whatever descriptions, if any, he knew these limitations. Although it is inappropriate to speak of God 'belonging' 
anywhere, in a purely conceptual sense he 'pertains' to this space, as do other unobservables such as scientific entities, like gravity" (Archer, 2004, p. 68).

As Stein (2002) argues, no-one will doubt the reality of a newborn child's experience when cradled in its mother's arms, even though it lacks all language and cognitive abilities. If, therefore, by following a prescribed method, one can obtain sensory verification of the Supreme, that experience should not necessarily be reduced to a product of social and historical conditioning but should be recognised in rational debate. Throughout history there have been many claims to religious experience, but, due to the dominating conceptions of the self, academia has regarded these as a product of social construction or simply as irrelevant. When allowed to present evidence of transcendental experience though, sacred forms of knowledge like the Vedas are admissible in rational debate. 


\section{Chapter Four: Non-Dualist Vedic Accountability}

As described, non-dualist Vedic philosophy holds that the fundamental constitution of reality is an all-pervading, undifferentiated spiritual energy of oneness. As Saravanamuthu describes:

"There are two schools in the Vedic tradition: Advaitism and Dvaitism [Nondualism and Dualism]. The former is grounded in the concept of 'oneness' or the union of the subject and object (or the spiritual oneness of all beings: Dalton, 1993), whereas Dvaitism is premised on a dualist interpretation" (2006, p. 296).

The Vedas call this non-dual substance brahman, and non-dualist philosophers hold it to be the primary ingredient of reality. They often refer to brahman, for lack of a better English word, as God. For example, when defining her use of the term God, Saravanamuthu cites the famous non-dualist philosopher Svami Vivekananda, who defined the Supreme as, "the sum total of intelligence manifested in the universe," whereby, "all the forms of cosmic energy, such as matter, thought, force, intelligence, and so forth, are simply the manifestation of that cosmic intelligence" (Svami Vivekananda, Lecture on 'Jnana-Yoga. The cosmos: The macrocosm.' Delivered in New York on 19 January 1896, quoted in Rolland, 1988, p. 262, again quoted in Saravanamuthu, 2006, p. 311). Based on this, Bhaskar (2000) - like many others - holds that man himself is God.

Saravanamuthu (2006, 2007) presents a theory of sustainable accountability informed by this advaitic philosophy. Because it is based on the notion that all forms of life are interconnected, such accountability radically expands the scope of a corporate entity's reporting obligations. This chapter examines Saravanamuthu's non-dualist theory of accountability so it can be compared with a dualist one later. Firstly, though, Bhaskar's (2000) description of the self in non-dualist Vedic philosophy is used to illustrate the non-dualist position.

\section{The Self in Non-Dualist Vedic Philosophy}

Taking the primary ingredient of reality to be the impersonal sum of all energies, Bhaskar asserts that man is God - though man does not realise this because of 
layers of avidya (ignorance) and maya (illusion) that cloud reality and make features like individuality and personality appear factual:

"The essential thesis of this book is that man is essentially God (and therefore also essentially one, but also essentially unique); and that, as such, he is essentially free and already enlightened, a freedom and enlightenment which is overlain by extraneous, heteronomous determinations which both (a) occlude and (b) qualify this essential fact" (2000, p. ix).

Similarly, Gupta praises Svami Vivekananda for propagating the same notion: "Vivekananda emphasized the great Vedantic realization of "I am Brahman" or "I am God" as the highest truth for all people" (2007, p. 643). The dualist philosopher will not deny that everything has its source in brahman, but will disagree that brahman is the fundamental source of existence. In the BhagavadGìtā, Krishna states, brahmano hi pratisthāham: "I am the basis of the impersonal brahman" (Bhaktivedanta Svami, 1989, verse 14.27). Krishna is therefore known as Parabrahman - the Supreme Brahman (Bhaktivedanta Svami, 1989, verse 10.12). To be true to the Vedas, then, the dualist philosopher recognises the ultimate ontological reality to be personal rather than impersonal. As there is personality in manifestations of the source, it follows that the source must be personal. Personality cannot come from an impersonal object, just as a drop of salty water cannot come from a freshwater lake. A person, however, can display both personality and be impersonal. The dualist will therefore attribute the ultimate source with an individual personality.

Unconscious to this, Bhaskar claims that man, upon forgetting his Godlike nature and acting on the premise that he is different from the rest of the universe, creates further contradictions and forms of conceptual alienation. Bhaskar refers to this forgetfulness as self-alienation:

"This chain of avidya secrets a veil or veils, which together form an interlocking web or meshwork of illusions. This (irrealist) web (or ensemble) holds contemporary thought in thrall, generating aporiai, contradictions, lacunae, conflicts, splits, anomalies, crises and many other modes of oppositionality 
within it... This real alienation (and conceptual alienation to which it gives rise) is in turn ultimately explained in terms of self-alienation" (2000, pp. 5-6).

Bhaskar states that the attempt to eliminate suffering without first attending to its causes is myopic, and thus he holds that self-alienation may only be remedied through the reinstatement of the true nature of the self as one with the rest of the cosmos:

\footnotetext{
"The resolution of the problem of agency is grounded in a radically transformed conception of the self, of being and identities. What I do depends upon my dharma, i.e. my intrinsic nature. This will be spontaneously right action. The question of agency therefore depends on resolution of the question of the self" (Bhaskar, 2000, p. 66).
}

\section{Gandhi-Vedic Accountability}

Saravanamuthu (2006), in formulating a non-dualist theory of Vedic accountability, gives a similar account of reality as Bhaskar. She constructs her theory on the foundation of Gandhian economics, which itself is secured in the bedrock of advaitic Vedic philosophy. She states:

"[Advaitic Vedic philosophy]... is constructed on the presumption that all forms of life have been projected from a mass of energy" (Saravanamuthu, 2006, p. 299).

Because the entire ecosystem emanates from one source and is thus interconnected, non-dualism holds that by harming another, one is causing harm to one's own self (which is non-different to the other). Gandhian economics, then, and any theory of accountability formulated upon it, proceeds on the karmic premise that every action generates knock-on consequences, "because elements of the whole are interconnected to each other" (Saravanamuthu, 2006, p. 297). It is this advaitic premise of spiritual interconnectedness that Saravanamuthu harnesses as a mount for a theory of sustainable accountability:

“... one's responsibility for the other (or spiritual interconnectedness) minimises the likelihood of circular dialectics of social contradictions: it reduces the 
chances that hazardous norms of risk society may be perpetuated" (2006, p. 306).

The goal of extended responsibility in Gandhi-Vedic accountability is ahimsic (non-violent) outcomes, or outcomes that are harmonious with the interconnectedness of the entire ecosystem. In order for systems of accountability to produce such outcomes, Saravanamuthu (2006) employs Gandhi's concept of satyagraha (non-violent resistance). This works for ahimsic outcomes, she explains, by employing moral and political means to engage interested parties in a reasoned dialogue. Through these means, satyagraha seeks to empower a weaker party by refusing their consent to the hegemony of exploitation whilst discursively engaging with those in positions of power (Saravanamuthu, 2006; Ghosh, 2007). Saravanamuthu states that, in the case of animal welfare, satyagrahic responsibility "argues for the rights for all creatures (from the multitudes of insects that keep the ecosystem ticking over to the animals reared for human consumption) that should be respected in animal husbandry practices" (2006, p. 312). Thus, as this example illustrates, new ahimsic outcomes are reached by considering the entire ecosystem to be interconnected.

Gandhian economics holds that an individual becomes trapped in a treadmill of alienation and exploitation by consenting to social norms emanating from the logic of control, or as Saravanamuthu explains, individuals create a "rod for their own back" (2006, p. 304). The Australian Government's proposal to compress and store Greenhouse gasses underground instead of reducing reliance on fossil fuels is one example of such logic, as these "band-aid fixes" to degradation do not eliminate the underlying causes of unsustainable practices (Saravanamuthu, 2006, p. 305). Such temporary solutions, she states, result in fresh contradictions that simply replace the previous set. Gandhi's advaitic Vedic paradigm is designed to prevent such unsustainable practices by encouraging a "reflexive" rather than a "fear" response:

"An individual who faces a new set of circumstances (such as temporary socioenvironmental degradation) may respond either reflexively, or out of fear. A reflexive response occurs when a person copes with an unfamiliar challenge by modifying her/his mental schema to create a 'what is' reality. It is accompanied 
by a conscious decision to modify one's behaviour, expectations and values. Therefore reflective behaviour is the ability to cope with changing circumstances. A fear response avoids the challenges that accompany change by resorting to the comfort of familia 'what was' realities. It effectively shuts out and perpetuates the logic of exploitation. Behaviour that is dominated by 'what was' perceptions will continue to fragment time and space dimensions of the whole by privileging private interests over the whole" (Saravanamuthu, 2006, p. 306).

Thus Saravanamuthu explains that 'what is' realities, produced via reflexive responses, create ahimsic outcomes, based on the concept of the self being interconnected with the entire ecosystem. The satyagrahic method of accountability produces a reflexive response by, "escalating the tension between opposing parties (through political and moral means) until the point where a common interest between the parties becomes so obvious that they engage in a dialogue to resolve the conflict" (Saravanamuthu, 2006, p. 308). Its goal in accounting is to engage parties in a discourse that minimises the fragmentation of time and space and thus makes individuals more conscious of their actions. Conventional accounting thought, Saravanamuthu (2007) explains, prioritises the pursuit of profit above social and environmental concerns, and is therefore based on the shortest temporary cycle. Hence a profit orientation fragments the environment's longer time dimension. Similarly, mainstream accounting is concerned with legal space as opposed to environmental concern that requires, according to Saravanamuthu (2007), an awareness of interconnected spaces or the interconnected ecology that advaitic Vedic philosophy describes. Through engagement in a discourse that minimises time and space fragmentations, tensions between conflicting perspectives will escalate until common ground is reached - a resolution achieved between the two parties that is in both of their interests (Saravanamuthu, 2006, 2007). Saravanamuthu asserts that decisions based upon such a framework of accountability will bring outcomes more consistent with a non-dualist conception of self, and this will manifest more sustainable behaviours in society.

To incorporate Gandhi's satyagrahic method of escalating tensions between opposing parties, Saravanamuthu (2006) proposes three general tools for 
accounting systems: customised accountability, the minimised dichotomisation between means and ends, and increased reflexivity. Customised accountability is an instrument that Saravanamuthu (2006) derives from the Gandhian requirement for political and economic independence. She states that, "information used to provide accounts to the other should be tailored to local circumstances: it follows on from the fact that the Gandhian-Vedic outcomes are context related" (Saravanamuthu, 2006, p. 316). For non-dualist accountability, then, customised accountability is part of the reform agenda that facilitates a reflexive rather than a fear response, as it will enrich perceptions of "what is" realities instead of taking shelter in the "what was" hegemonic rhetoric that emerges from a "one size fits all" governance framework (Saravanamuthu, 2006, p. 317). Dichotomisation of means and ends, Saravanamuthu explains, puts greater emphasis on the means used to ascertain the end - instead of relying on the outcome, especially endless economic growth, to justify the means (2006, p. 318). Finally, she states that increased reflexivity embraces greater responsibility to the other based on the advaitic premise of spiritual interconnectedness: "a person is more likely to respond reflexively to 'what is' challenges of risk society when the person is able to associate her/his reality with the needs of the other" (2006, p. 318).

In relation to Laughlin's (1996) model of accountability, it can be seen that the Gandhi-Vedic model is not concerned with accounting to a higher principal. Instead, an effort is made to achieve a consensus, or a common interest between parties that is more conscious of their interconnected nature. This absence of accountability to a higher principal stems from the advaitic Vedic concept that God is impersonal, and man is the highest principal. Gandhi-Vedic accountability, though, does hold some similarities to Robert's socialising forms of accountability. As Roberts states, socialising forms of accountability work for the acknowledgement of others, and to articulate differences through talk. "Rarely perhaps", he explains, "does such talk explicitly aim at achieving consensus, but undoubtedly it is the basis of mutual understanding, and consensus, albeit fluid and transitory, may be its unintended consequence" (Roberts, 1991, p. 362). It was seen that the satyagrahic method of accountability would be tailored to local circumstances and be designed to produce reflexive responses by "escalating the tension between opposing parties (through political and moral means) until the point where a common interest between the parties 
becomes so obvious that they engage in a dialogue to resolve the conflict" (Saravanamuthu, 2006, p. 308). Similarly, in Saravanamuthu's (2007) case study of the Riverlands citrus industry, the horticulturalists attempted to initiate a rational discourse between producers, consumers and regulators to highlight the common interests of environmentally sustainable action. Thus satyagrahic accountability has similar objectives as Roberts' socialising forms.

It cannot be said, however, that Gandhi-Vedic accountability possesses all the features of Laughlin's (1996) communal accountability, such as high trust, low potential for conflicting interests and ex-post reporting. Rather, satyagrahic accountability has more contractual features - such as radar plotting and the minimised dichotomisation between means and ends - in order to highlight the common interests of sustainable action. Therefore, instead of subduing conflicting interests with individualising forms of accountability, Gandhi-Vedic accountability uses explicit reporting requirements to tease out common interests, and to reach a consensus. Therefore satyagrahic and socialising forms of accountability have a similar destination, but different paths are taken to reach that conclusion. Rather than being left to their own devices, under Gandhi-Vedic accountability agents would be required to fulfil additional reporting obligations so that ahimsic outcomes might be achieved. In this way, satyagrahic accountability can be compared with Shearer's (2002) appeal for a greater accountability to the other: it was seen that under the neoclassical doctrine, the individual was motivated by self-interested action, and was thus only held accountable for such. In contrast to the neoclassical model, an advaitic theory of accountability assumes that all forms of life are interconnected. Interconnectedness becomes a defining characteristic of Gandhi-Vedic accountability that Saravanamuthu refers to as increased reflexivity, which is specifically aimed at broadening the scope of accountability to the other:

“... one's responsibility to the other (or spiritual interconnectedness) minimises the likelihood of circular dialectics of social contradictions ... it reduces the chances that Beck's (1993) hazardous norms of risk society may be perpetuated. ... Spiritual development involves curtailing the human ego by detaching private interests from one's thoughts and actions. Therefore, Gandhi's ideas of non-violence, satyagraha and swaraj are directed at sacrificing the self, or ego 
.. because it minimises inner conflicts (or personal contradictions)" (Saravanamuthu, 2006, p. 306).

Thus the Gandhi-Vedic theory of sustainability functions by making one aware of what Saravanamuthu calls "what is" realities (2006, p. 306), through various contractual accounting devices. This has some semblance to Shearer's accountability for the other, and it has similar ends as Roberts' socialising forms of accountability, but does not recognise an obligation to any divine higher principal.

\section{The Riverlands Citrus Industry's Satyagrahic Journey}

Saravanamuthu (2007) applies the tools for satyagrahic accountability to the case study of a networked community in South Australia. By relating her findings and suggestions from the case study of a segment of the citrus industry in the Riverlands region, which faced sustainability issues, it is possible to observe an example of non-dualist Vedic accountability. The citrus horticulturalists had realised that their practices were not sustainable in the long term, as their dependence on irrigation had upset the ecological balance in the Riverland's arid environment. Saravanamuthu (2007) reports that, unsatisfied and disempowered by the ends based feedback associated with conventional management practices, the blockies had begun to search for more sustainable horticultural techniques. ${ }^{10}$

In 2003, a group of blockies incorporated themselves as the Movement for Environmentally Sustainable Horticulture (MESH), and initiated what Saravanamuthu (2007) likens to Gandhi's satyagrahic journey, whereby the satyagrahic method of accountability produces reflexive responses through increased transparency. Saravanamuthu (2007) describes how MESH secured reflexive responses by implementing systems of accountability that would eventually establish a farm-to-market network for its produce, along with a database containing operational data for all its participating blockies that would be duly audited to ensure customers that its members were adhering to its ethos. It was MESH's aspiration that customers would be able to perceive the citrus farm's output as products rather than commodities, as each product has a story

\footnotetext{
${ }^{10}$ Saravanamuthu (2007) uses the South Australian term 'blockies' because, she explains, each horticulturalist cultivates, on average, a 30-hectare block of land.
} 
behind it - specifically of how the Riverlands community endeavoured to grow its produce in a sustainable fashion.

Amongst the accountability techniques developed by MESH to achieve this communicative action was a manual of best practices (MESH, 2003) that identified priority areas and measurements aimed at achieving higher levels of sustainability. As Saravanamuthu describes, MESH's endeavour for sustainable horticulture began by scrutinising the most fundamental assumptions:

"...a lot of people have no idea of exactly what a healthy tree looks like...people think that something that is nice bright black green is healthy, but it is not. The greener it is, the more vulnerable it is...because it indicates...a high level of nitrogen, and maybe phosphate as well...If you look under a microscope...if it has too much nitrogen... you will have gaps between the cell walls, the cell walls will be weak and sap-sucking insects like your thrips... will attack that plant because it is very easy to get in and...have a drink" (O (i) blockie, quoted in Saravanamuthu, 2007, p. 26).

This manual of best practices moved the blockies from generic horticultural categories to more sustainable management techniques - each MESH blockie would measure the impact of his horticultural methods on the surrounds, and any method that inflicted less destruction would be included in a pool of more sustainable practices. Thus Saravanamuthu (2007) describes how MESH blockies built up a collection of increasingly sustainable horticultural techniques into an emergent vocabulary of horticultural cultivation that would draw the best practices from the existing methods and advances in agricultural science. Their reform agenda would then be subjected to review with a range of auditing processes, from self-audits to peer-reviewed third party audits. As Saravanamuthu (2007) describes, these steps are part of a larger vision of constructing a networked community containing everyone from producers to final consumers. Such a connection has some resemblance to Gandhi's satyagrahic action intended to generate reflexive responses:

“MESH's communicative action is similar to Gandhi's satyagraha because it increases the likelihood of rational discourse between producers-customers- 
regulators by using marketing and informational strategies to cast politicoeconomic influences to highlight their common interests (following Pareka, 1991). The term "rational" refers to reasoned dialogue in the context of uncertainty and ambiguity about the totality of Gaiaic interconnections. ${ }^{11}$ The common interests in the Riverland emanate from the tight inter-connection between the health of the catchment and industry community" (Saravanamuthu, 2007, p. 24).

The MESH manual of best practice, however, did not altogether meet Saravanamuthu's qualifications of satyagrahic accountability and therefore her subsequent research was directed at supplementing implementations made by the Riverlands community to provide holistic feedback that might tailor accounts to generate more reflective responses. To this end, she recommended radar plots as a vehicle of sustainability accountability:

"The radar plot is a diagrammatic representation of the satyagrahic ethos because its equal representation of conflicting-and-complementary feedback increases tension between stakeholders through dialogue, which in turn makes the common interest binding stakeholders all the more apparent" (Saravanamuthu, 2006, p. 331).

Radar plots can be a tool for satyagrahic accountability, Saravanamuthu (2006) explains, because their representation of performance minimises the fragmentation of time and space. Essentially they locate performance within the broader context of risks and dangers, and thus they translate, very concisely, a verity of measurements on a graduated scale of high to low risk impact. Saravanamuthu claims that, in her case study of the Riverlands citrus industry, radar plots would grant equal representation to known horticultural consequences whilst highlighting their relative risk:

"Viewed in its entirety, the spokes of the radar plot represents the multi-faceted impact of human activities on land, water, atmosphere and bio-diversity. Each of

\footnotetext{
11 Saravanamuthu uses Lovelock's (1995) Gaia theory to aid in explaining her notion of sustainability: "Gaia, an ancient Greek divinity on Earth, refers to the highly coupled connection between the Earth's creatures and its atmospheric, terra firma and hydrologic elements that regulate and sustain life" (2007, pp. 3-4).
} 
the radar plot's spokes represents a different measure of performance, which has been subjectively standardised on a graduated scale of risk. Risk assessments are juxtaposed against each other to provide comparative yet holistic representations of risk-danger. The tighter the area (from the origin) between the spokes, the less the degree of risk posed by the horticultural practices to the health of the catchment" (2007, p. 28).

Through such accountability methods, Saravanamuthu (2007) proposes that outcomes more aligned with the advaitic premise of interconnectedness would be achieved. Radar plotting, along with the other accountability techniques mentioned, would increase the likelihood of reflexive responses made upon "what-is" realities. Through such accountability methods, she states, members of networked communities can access, question and contest taken-for-granted assumptions, and thereby scrutinise conditions to reach a common interest between contracting parties. 


\section{Chapter Five: Dualist Vedic Philosophy}

The non-dualist theory of sustainable accountability presented by Saravanamuthu (2006, 2007) is based upon the advaitic conception of reality that everything is one. With the entire ecosystem being interconnected, to harm one part of the whole is to harm oneself. As Saravanamuthu explains, based on this conception of reality, advaitic accountability is designed to generate reflexive decisions which lead to ahimsic outcomes. Bhaskar (2000), also coming from the advaitic paradigm, similarly explains that contemporary societal ills may be cured by correcting the ontological error that one's self is a separate entity from the rest of the cosmos. What Saravanamuthu and Bhaskar describe, then, is a theory of sustainability (or sustainable accountability) based on the non-dualist conception of the self.

Dualist Vedic philosophy readily acknowledges that such accountability would create more sustainable outcomes than current systems that fragment time and space. With its foundations in neoclassical economic theory, the notion of the self in mainstream accounting is what Weale (1992) terms Homo Economicus. As a species, Homo Economicus is prone to self-interested utility maximising behaviour, and thus mainstream accounting recognises no obligation for an economic entity to account for anything but the pursuance of what neoclassical economics determines is its own interest - the maximisation of shareholder wealth (Shearer, 2002). In stark contrast, Saravanamuthu's advaitic accountability advocates a broader scope of analysis that includes, for instance, animal welfare (Saravanamuthu, 2006).

Whilst acknowledging the superiority of non-dualist accountability over the conventional, dualist Vedic philosophy asserts that higher levels of sustainability and societal wellbeing are attainable by aligning systems of accountability with a dualist conception of the self. Gaudīya-Vaisnavism does not consider the self to be material, as pure dualists or materialists might. Nor does it conclude that the self has no personal identity because it is one with the rest of the ecosystem, as the monist philosophy does. Instead, Vaisnavism recognises the self as different from the material body and a part of the Supreme. When his needs in relation to the Supreme are met, one is no longer impelled by the dictates of the material body and mind. Hence a dualist theory of 
accountability encourages a sustainable pattern of desires and consumption. Under non-dualist accountability, however, one's needs in relation to the Supreme go unfulfilled, because neither the self nor God are recognised as individuals or as personal in nature. Dualism offers a more sustainable form of accountability because if the needs of the self are met one has no desire to engage in unsustainable patterns of consumption, and because of a higher level of satisfaction one willingly changes his values, desires and behaviours. Under the non-dualist theory of accountability that Saravanamuthu (2006) has described, behaviours and values are influenced when satyagrahic discourse is employed but no higher form of satisfaction than sensory pleasure is provided for, unlike a Vaisnava theory of accountability. This chapter prepares the way for a description of the dualist theory of accountability by describing its underlying philosophy and its conception of the self.

\title{
Dualist Vedic Philosophy
}

As explained in the second chapter, the Vedic text Bhagavad-Gitta summarises the essential principles of Vedic philosophy. The dualist conception of the self is explained in several chapters of the Gittā, but since this thesis also refers to nondualist Vedic philosophy, it is helpful to begin a description of dualism with the Gìtà's seventh chapter. This explanation will make it possible to locate materialist, non-dualist and dualist forms of accountability within the theoretical framework presented by Krishna. At the beginning of the seventh chapter, Krishna declares to Arjuna that He will summarise everything in the universe, both material and spiritual. His words read:

\author{
jñanam te 'ham sa-vijñānam \\ idam vaksyāmy aśesatah \\ yaj jũātvā neha bhūyo 'nyaj \\ jñātavyam avaśisyate
}

"I shall now declare unto you in full this knowledge, both phenomenal and numinous. This being known, nothing further shall remain for you to know" (Bhaktivedanta Svami, 1989, verse 7.2). While this may seem an immense task to accomplish in one conversation, Krishna nonetheless completes it in the next 
few verses. His framework describes everything as either His superior or His inferior energy. Krishna begins by listing His inferior energies:

\section{bhümir āpo 'nalo vāyuh \\ kham mano buddir eva cā̄ \\ ahankāra itīyam me \\ bhinnā prakrtir astadhā}

"Earth, water, fire, air, ether, mind, intelligence and false ego - all together these eight constitute My separated material energies" (Bhaktivedanta Svami, 1989, verse 7.4). Other Vaisnava commentators have translated earth, water, fire, air and ether as solid, liquid, and gaseous matters, radiant energy and empty space in other words, Krishna is listing His energies in the descending order of their perceptibility.

From the Vedic perspective, reductionist material science is concerned mainly with the first five categories of inferior energy that Krishna described, namely solid liquid and gaseous matters, radiant energy and empty space. Psychologists and philosophers also address mental activities. Hines, for instance, suggests that accounting should include the emotional values of the "Universal Feminine," such as "the prioritising of feelings; the reality and value of the non-marketable and non-material" (1992, p. 314). Finally, non-dualist Vedic philosophy is concerned with all eight of these energies and nothing more, their source being the impersonal brahman. These substances are described by Krishna as inferior energies because, by themselves, they lack the presence of consciousness. In the next verse Krishna explains that it is His superior energy, the living entities, that exhibit the consciousness that causes the material energy to function:

apareyam itas tv anyām

prakrtim viddhi me parām

jiva-bhūtām mahā-bāho

yayedam dhäryate jagat 
"Besides these, O mighty armed Arjuna, there is another, superior energy of Mine, which comprises the living entities who are exploiting the resources of this material, inferior nature" (Bhaktivedanta Svami, 1989, verse 7.5). While the Bhagavad-Gìtā admits that the living entities cannot be directly perceived, it also asserts that their presence can be known by certain symptoms, just as the movement of clouds and dust indicate the wind's currents. Elsewhere in the Gittā, Krishna denotes consciousness as the symptom that indicates the presence of the living entity:

\section{yathā prakāśayaty ekah \\ krtsnam lokam imam ravih \\ ksetram ksetrī tathā krtsnam \\ prakāśayati bhārata}

"O son of Bharata [Arjuna], as the sun alone illuminates all this universe, so does the living entity, one within the body, illuminate the entire body by consciousness" (Bhaktivedanta Svami, 1989, verse 13.34). Sometimes the sun is not directly seen because the sky is filled with clouds, yet because of the light of the sun, one is convinced that the sun exists. Similarly, in the above verse, Krishna asserts that consciousness is the symptom that indicates the presence of the living entity, even if he may not be directly perceived. Furthermore, Krishna explains here that consciousness is not a product of chemical combinations, as material science asserts. After death, when the body no longer exhibits any consciousness, the same chemicals are present in the body as during life, yet consciousness is absent, and cannot be revived. Therefore dualist Vedic philosophy holds that consciousness is not a product of combinations of matter but is a symptom that indicates the presence of the living entity. ${ }^{12}$

According to the Bhagavad-Gìtā, conventional forms of accountability limit their concern to the eight inferior energies that Krishna listed which lack consciousness. Considering Smark's (2006) contention that accounting does not factor the indirect costs of schizophrenia, and Saravanamuthu's (2006)

\footnotetext{
${ }^{12}$ Many further issues arise from this assertion, and it is not within the scope of this thesis to consider them all. Interested readers, however, may refer to Cremo (2003) for a comprehensive description of the Vedic explanation of consciousness.
} 
arguments that it excludes large portions of the ecosystem by labelling them as externalities, it may be argued that mainstream accounting does not even cater for inferior energies very well. Academics therefore advocate more social and environmental forms of accountability by campaigning for the improved accounting of these eight energies, such as the above example from Hines (1992), who suggested accounting should extend its concern to the functions of the mind. According to the Bhagavad-Gìtā, though, none of these forms of accounting consider the needs of the conscious self, who is different from the material energy. Without considering the needs of the conscious self, any theory of sustainable accountability will inevitably be limited in its effectiveness. This is evident in Druhl et al. (2001) who, also writing from the Vedic paradigm, identify the consciousness of an organisation's individual members as a unifying basis for organisational management and change. The two conventional approaches to organisational change, "planned change" and the "learning organisation", often meet with limited success, and Druhl et al. attribute this to each approach addressing only a partial aspect of the organisation and failing to identify a common area of organisational life, from which all aspects of the organisation can be understood and managed. In their analysis they identify the elusive conscious self - the target of Vedic inquiries:

"What is missing in the classical and quantum paradigms so far is a systematic, scientific approach to this subjective element as a potentially unifying basis for managing the whole range of diverse aspects of the organization. ... A complete understanding of the organization and a correspondingly successful strategy of change will emerge only when this missing element is included. In the area of quantum physics we have identified the subjective element to be the observer. In the area of organizations and social relations we now locate the subjective element in the individual member of the organization. By the individual member here we are referring not to the individual's position or role, which are structural aspects, nor to his or her social interactions, which are behavioral aspects. Rather, we are referring to the individual's inner nature, his awareness or consciousness, the inner wakefulness which perceives, the subjective screen on which position, role and interaction are seen and from which they are organized" (Druhl et al., 2001, pp. 389-390). 


\title{
The Self in Dualist Vedic Philosophy
}

Dualist Vedic philosophy establishes a difference between matter and the conscious living entity, or a difference between the material body and the conscious self. This is illustrated by Krishna at the beginning of the BhagavadGìtāa, where He states:

\section{dehino 'smin yatā dehe \\ kaumāram yauvanam jarā \\ tathā dehāntara-prāptir \\ dhīras tatra na muhyati}

\begin{abstract}
"As the soul continues to pass, in this body, from boyhood to youth to old age, the soul similarly passes into another body at death. A sober person is not bewildered by such a change" (Bhaktivedanta Svami, 1989, verse 2.13). Linyanarachchi (2007), in describing a Buddhist theory of accountability, advances the concept of samsāra - the continuous repetition of birth and death.
\end{abstract} The notion of repeated lives is present in the Vedas as well, but in the verse above Krishna explains that the self inhabits different material bodies, not just in different lives, but also within one lifetime. Contemporary medical science accepts that the chemicals that comprise the material body change over a period of approximately seven years, as new cells are created and the old are discarded. If all chemicals of the human body are constantly being replaced, then it follows that the body is a different set of chemicals in youth than in childhood. Again, in old age, the body is comprised of an entirely different set of chemicals due to cell replacement. Thus the living entity not only changes bodies at death but also throughout his current life. The consciousness of the living entity, however, does not change or die, nor does one's identity change with the change of the chemical composition of the body. Instead the living entity retains the same consciousness throughout their entire lifetime, and thus the self cannot be the material body.

With the identity of the self different from the material body, dualist Vedic philosophy asserts that one cannot find satisfaction through indulgence of the body's senses. One's identity is different from the vehicle they drive, and thus they do not consume the fuel of the vehicle for their own enjoyment - to do so would only cause frustration. Similarly, the Vedas explain that one has a 
separate identity from the material body, and therefore to try and attain satisfaction solely through the senses of the body will result only in frustration. Nonetheless, the Vedas support the careful maintenance of the body - although one has a separate identity from their vehicle, this does not impel them to destroy it. Instead a vehicle is carefully maintained so it can achieve certain ends. Similarly, the Vedas encourage the maintenance of the body so it can be used for spiritual rather than material ends. In this regard, the Śrimad-Bhāgavatam states:

\section{kāmasya nendriya-prītir \\ lābho jīveta yāvatā \\ jīvasya tattva-jijñ̄as $\bar{a}$ \\ nārtho yaś ceha karmabhih}

"Life's desires should never be directed towards sense gratification. One should desire only a healthy life, or self-preservation, since a human being is meant for inquiry about the Absolute Truth. Nothing else should be the goal of one's works" (Bhaktivedanta Svami, 1987, verse 1.2.10). The dualist consideration is that material objects like the body can be utilised for spiritual purposes, just as an iron rod, when heated in fire, takes on the properties of fire. Biswas (1998) therefore explains that the Vedas permit economic development and wealth accumulation, not as ends in themselves, but as means to a higher end. Chakraborty and Chakraborty (2007) also claim that the Vedas view the desire for a decent material life not as a hurdle but as an enabling factor for fulfilling the supra-material aspirations of life.

As Velayutham and Perera (1996) stated, different theories of accountability become manifest from different metaphysical notions of the self, and therefore a dualist conception of the self as different from the material body has profound implications for theories of sustainable accountability. It is not sufficient, however, simply to know that the self is not the material body. To formulate a theory of accountability, positive information of the real identity of the self and its needs is also required - as Devamrita Svami states, "we cannot account for the cosmos without accounting for the accountant" (2002, p. 100). Rather than being one with God, as non-dualists assert, the Bhagavad-Gìtā holds that the self is eternally a part of the Supreme: 


\section{mamaivamśo jiva-loke \\ jīva-bhūtah sanātanah \\ manah-sasthānīndriyāni \\ prakrti-sthāni karsati}

"The living entities in this world are My eternal fragmental parts. Due to conditioned life they are struggling very hard with the six senses, which include the mind" (Bhaktivedanta Svami, 1989, verse 15.7). ${ }^{13}$ Psychologists assert that, in general, humans seek pleasure and try to repel distress (Layard, 2005). The reason, according to the Vedas, is that all living entities are parts of Krishna, Who is also pleasure-seeking in nature. As a drop of seawater has the same salty characteristics as the ocean, so does the living entity have the propensity to seek pleasure, for this propensity is inherent in God. Because humans, and all other forms of life for that matter, share the same pleasure-seeking tendency, it demonstrates that they are all parts of a Complete Whole that is pleasure seeking in nature.

When under the impression that he is the material body, the living entity seeks satisfaction through matter by gratifying the senses of the body. As the above verse of the Gitta demonstrates, the Vedas include the mind as a sense organ, and the functions of the mind are described as thinking, feeling and willing - therefore the Vedic definition of materialism is inclusive of subtle forms of enjoyment as well as more gross forms. The Vedas explain, however, that actual satisfaction may only be attained by satisfying God, as the living entities are His parts. This follows from the Vedic definition of God as bhoktāram yajña-tapasām - the ultimate beneficiary of all sacrifices and austerities, or the Supreme Enjoyer (Bhaktivedanta Svami, 1989, verse 5.29). An example is that part of a machine co-operates with the whole of the machine, and a part of the body co-operates with the rest of the body. The different parts of the

\footnotetext{
${ }^{13}$ Saravanamuthu raises the question, "Why did God need to create anything if he is complete and perfect?" (2006, p. 312). This question may be answered with Krishna's statement, "The living entities in this world are My eternal fragmental parts" (Bhaktivedanta Svami, 1989, verse 15.7). Although all the living entities themselves have individual personality, they are, nonetheless, fragmental parts of God. Therefore, in answer to Saravanamuthu's question, the Vedic conception of God includes all living entities as well, and therefore God has not created anything outside of Himself, rather He is still complete and perfect.
} 
body, the hands, legs, eyes and so on, are not actually the enjoyers. The digestive system is the enjoyer because only it has the ability to assimilate the energy of the food. If different parts of the body are to be kept healthy, all respective parts of the body must feed the digestive system and thus be nourished. The different bodily parts cannot obtain nourishment without satisfying the digestive system, and similarly, as parts of Krishna, living entities must satisfy Him in order to feel fully satisfied. As Bhaktivedanta Svami states:

"A person should act in such a way that the Lord is satisfied by the activity; it is not that he himself is to be satisfied. Of course, when the Lord is satisfied, the devotee automatically becomes satisfied. This is the secret of the process of bhakti-yoga" (1987, Fourth Canto, p. 514).

This service to God is also the Vedic conception of love, as one cannot claim to love God without rendering Him service. In describing love of God, McKernan and Kosmala (2007) incorporate Derrida's conceptions of "the possibility of the impossible" (Derrida, 1993, p. 43, quoted in McKernan and Kosmala, 2007, p. 733). They state that love of God is, "passion for the impossible," and, "a going out to the other without demanding that the other compromise its alterity: it is a giving of oneself as a gift without calculating the return" (McKernan and Kosmala, 2007, p. 734). The Vedic conception of love, however, is more straightforward: one cannot claim to love their husband or wife and yet, simultaneously, be negligent of the desires of their partner. Therefore to love God also means to serve God.

A dualist theory of accountability, then, recognises these two central points concerning the self: firstly, the living entity is not the material body, and sensory pleasures, by themselves, will not satisfy him; secondly, the living entity is a part of God and thus his satisfaction depends upon the satisfaction of the Supreme. Therefore dualist accountability simultaneously performs two functions: the first recognises the difference between body and self by not attributing value to unnecessary sensory engagements, and the second ascribes value and recognition to activities that bring pleasure to the Supreme. Herein lies one essential difference between dualist and non-dualist systems of accountability. In order to stimulate the reflexive responses that generate ahimsic 
outcomes, Saravanamuthu (2006) claimed that advaitic accountability would utilise Gandhi's satyagrahic methods of reducing the fragmentation of time and space, thereby making people more conscious of their actions. Decisions would thus be made on information that treated the ecosystem as an interconnected whole - in this way more externalities would be internalised, and a sustainable form of accounting would ensue. Whereas non-dualist accountability depends upon Gandhi's satyagrahic methods to overcome the "treadmill of alienation and exploitation" (Saravanamuthu, 2006, p. 304), dualism relies on transcending the bodily pleasures that bind one to such a treadmill, through attaining a higher taste experienced by the living entity when he harmonises his activities with the desires of the Supreme. Such a method of transcending lesser, sensory pleasures is mentioned in the Bhagavad-Gìta and is thus supported by the Vedas:

\author{
visayā vinivartante \\ nirāhārasya dehinah \\ rasa-varjam raso 'py asya \\ param drstvā nivartate
}

"The embodied soul may be restricted from sense enjoyment, though the taste for sense objects remains. But, ceasing such engagements by experiencing a higher taste, he is fixed in consciousness" (Bhaktivedanta Svami, 1989, verse 2.59). Such a transcending of inferior pleasures has been demonstrated as possible by Druhl et al. (2001), who advocate employment of the Vedic worldview and paradigm given by Maharishi Mahesh Yogi, commonly known as Transcendental Meditation, or simply as TM. This has its origins in non-dualist Vedic thought, and therefore is not representative of the dualist schools, which the Bhagavad-Gìtā asserts are more effective at transcending consumerist urges. However, the research of Druhl et al. will suffice to partially illustrate the dualist concept of a higher taste. They cite empirical benefits of TM practices in organisations and citywide settings. In one instance they refer to Rhode Island where during 1978 there was a slight increase in the practitioners of Maharishi's yogic tradition, which was significantly and positively associated with increases in the Island's composite quality of life index. The index included eight variables including beer and cigarette consumption and levels of air pollution: all showed 
significant improvement in 1978 compared with the previous four years (Druhl et al., 2001). Thus Vedic philosophy, in practice, may effect change where lower forms of enjoyment are transcended.

As Sharma and Talwar (2004) state, Vedic philosophy stresses that happiness lies in self-contentment not trying to fulfil material desires. By recognising a difference between the wants of the material body and the needs of the self, a dualist theory of accountability seeks to provide the means of achieving self-contentment. Self-satisfaction, or satisfaction absent the dependence on conditions for sensory enjoyment, is also possible in the nondualist Vedic paradigm, though Saravanamuthu does not mention this. Other commentators though, such as Ghosh (2007) and Gupta (2007), have alluded to it. Such self-satisfaction is more difficult to attain via the non-dualist process however, as is explained by Krishna in the Bhagavad-Gìtā, when His student, Arjuna, asks which is the most perfect - dualist or non-dualist methods of selfrealisation. Krishna replies that the dualist method is better because the nondualist method is klesah adhika-tarāh - "very troublesome." The verse reads:

\section{kleśah 'dhikataras tesām \\ avyaktāsakta-cetasām \\ avyaktā hi gatir duhka \\ dehavadbir avāpyate}

"For those whose minds are attached to the unmanifest, impersonal feature of the Supreme, advancement is very troublesome. To make progress in that discipline is always very difficult for those who are embodied" (Bhaktivedanta Svami, 1989, verse 12.5). The Śrimad-Bhāgavatam (Bhaktivedanta Svami, 1988, verse 10.2.32) further describes that the non-dualist platform of self-satisfaction is not enduring, for it provides no connection to a higher personal reality. In non-dualist philosophy, as Saravanamuthu (2006) describes, God is ultimately impersonal. However this is not supported in the Bhagavad-Gìtā, the essence of Vedic philosophy, as Krishna asserts that both $\mathrm{He}$ and the living entity eternally maintain their personality: 
na tvam name janādhipāh

na caiva na bhavisyāmah

sarva vayam atah param

"Never was there a time when I did not exist, nor you, nor all these kings; nor in the future shall any of us cease to exist" (Bhaktivedanta Svami, 1989, verse 2.12). If living entities are personal then an impersonal reality will not satisfy them - even on a material level, physiologists recognise that people are happier if they value good relationships and contribute to the community beyond consumerist enjoyment (Kasser, 2002; Layard, 2005). The Vedas assert the same for the self on a spiritual platform - personal relationships are more satisfying. Therefore dualist accountability can provide a higher platform of sustainability than non-dualist schools, even if the latter are orientated towards attaining selfsatisfaction. The great Vaisnava scholar, Prahlāda Mahārāja, illustrates this superiority of personalism over impersonalism in his prayers, which also indicate what might be possible under a dualist form of accountability:

"My dear Lord of the universe, I am feeling transcendental pleasure in Your presence and have become merged in an ocean of transcendental happiness. I now consider the happiness of brahmananda [non-dualist liberation] to be no more than the water in the impression left by a cow's hoof in the earth, compared to this ocean of bliss" (Hari-bhakti-sudhodaya, quoted in Bhaktivedanta Svami, 1970, p. 15).

\section{Dualist Vedic Accountability}

The previous section purported that dualist Vedic accountability is concerned with accounting for the self, not as the material body, but as a part of God. One of its central features is not attributing any positive value to the production, promotion or sale of consumerist goods and services - especially those that only stimulate the mind and senses, and are thus unnecessary for healthy maintenance of the material body. As the following chapter will detail, one cannot find satisfaction through senses of the body, and thus the supply of consumerist goods leads only to increasing consumption - an unsustainable situation. Therefore the 
production and marketing of consumerist goods and services that only gratify the physical and mental bodies would have no value in dualist Vedic accountability.

Dualist Vedic philosophy advances that the highest position of sustainability is achieved only when the senses are controlled through enjoyment that supersedes material sensory pleasures. Therefore the second feature central to dualist Vedic accountability is that the self is recognised as a part of the Supreme by attributing value to endeavours intended to bring satisfaction to the Supreme. The art, science and culture of pleasing the Supreme are described in the Vedic literatures, especially the Śrimad-Bhägavatam, which describes the activities of many transcendentalists. However, so the reader may understand what type of projects dualist Vedic accountability would attribute value to, an explanation is given in the seventh chapter. Essentially, though, dualist Vedic accountability would recognise value when other living entities are treated as parts of God rather than as their material body, and therefore such accountability would identify how other living entities were being benefited by the reporting entity by being freed of the bodily conception of life.

From this outline of dualist Vedic accountability, it is clear that it is concerned with accounting to a higher principal - namely Krishna, the Supreme Person. Dualist accountability, then, does not follow non-dualists, whose theory of sustainability depends upon satyagrahic discourse (Saravanamuthu, 2006). Instead dualist accountability is similar to the Islamic model, in that agents are held responsible to a higher principal. It is through the satisfaction of Krishna that a culture of sustainability is achieved, for by satisfying Krishna, His dedicated parts also become satisfied, who then transcend desires for unsustainable consumer enjoyment. Dualist accountability is also similar to Shearer's (2002) accountability to the other, for, as described in the seventh chapter, accounting for Krishna's desires includes accounting for the wellbeing of other living entities. Indeed, part of the agent's responsibility to Krishna lies in not misleading other living entities to believe that lesser forms of enjoyment will satisfy them, and therefore consumerist goods and services would not be attributed value under dualist Vedic accountability. As Chapters Six and Seven describe, the principle of not recognising goods unbeneficial to material and spiritual wellbeing also exists in Islamic accountability. 
Like Islamic accountability, the dualist model is not limited to the caring professions, but extends to the commercial sector. According to the Vedas, the real interests of principals and the agents lie in the satisfaction of God, regardless of what industry, sector or profession they are in. However, just as Islamic accountability assumed that not all agents are equipped with the knowledge and aspiration to satisfy their higher principal, dualist Vedic accountability does not assume that all principals and agents are free of the conception that they are the body and that sensory pleasures are ultimately unsatisfying. Dualist accountability is therefore generally contractual, for in many contexts where it would be applied there is not high trust and little potential for the conflict of values. It follows, then, that the principle cannot specify all the requirements for dualist accountability, for that principle may be lacking in the knowledge and practice of satisfying the Supreme. As will be described in the seventh chapter, in contemporary and traditional Vedic culture, a class of spiritual intellectuals would guide society in its accountability to the Supreme Principal.

Following Roberts (1991), such a dualist system of accountability, being more hierarchical and contractual, would produce a more individualised sense of self. However, acknowledging a higher principal in dualist Vedic accountability does not preclude it from adopting the techniques that Saravanamuthu (2006, 2007) has suggested for satyagrahic accountability - so long as the self is also recognised as a part of the Supreme. Also, there may be circumstances where dualist accountability would be better applied communally. Because of its attitude towards the sacred and the secular, dualist Vedic accountability may embrace any accounting procedure that would better consider the needs of the self. Therefore the various accountability tools that Saravanamuthu recommended - radar plotting, customised accountability, forward-looking accountability, minimisation of the dichotomisation between means and ends, and other such techniques - are within the scope of dualist philosophy if they improve the care of the environment and society while recognising the spiritual identity of the self.

Roberts (1991) also admits that the individualising of the self is not always undesirable. When taken in a context of exploitative disciplinary power, an individualised sense of the self has a detrimental effect to wellbeing, as 
Roberts describes. However, he also concedes the possibility of a beneficial sense of self emerging:

"One's absorption with objective appearance can be purely defensive or can be taken on more positively as a series of projects for the enhancement of the self. ... The individualised self can aspire to an ever more complete autonomy, and each level of the hierarchy apparently offers a move towards this; position in the hierarchy serving as an objective confirmation of relative value and worth. In practice of course one is drawn thereby further and further into conformity with the standards of utility upon which "success" depends" (1991, p. 360).

As Roberts explains, "accountability represents the attitudes of others towards us, and in this way both addresses and immediately confirms us" (1991, p. 358). Under a dualist theory, accountability is intended to confirm the self as a part of God whereby success is seen as satisfying the Supreme. Rather than being exploitative, such a conception is liberating for, as will be described, it frees one from the belief that matter is the summum bonum of everything by giving the possibility of genuine spiritual experience, and thus gives much opportunity for the development of character. Therefore the sense of self generated through dualist Vedic accountability is not undesirable. Roberts (1991) states communal accountabilities are limited to contexts without power asymmetries but with possible face-to-face interaction. Thus, when the case for individualising forms of accountability prevails, it is better that they produce a sense of self that is advantageous for the accountee.

Two significant features of dualist Vedic accountability have been identified as not attributing value to consumerist goods and services. To address the first research question proposed by this thesis - namely what would be the significant features of a theory of accountability informed by dualist Vedic philosophy, as represented by Gaudīya-Vaisnavism? - the following two chapters elaborate on these two features. In either a traditional or contemporary Vedic culture, the serious practitioner would consider himself accountable to Krishna as a higher principal, and would mould his life around these two ideals. Therefore, such a theory of accountability is relevant on an intrapersonal level. However, as the seventh chapter describes, being responsible to Krishna entails 
that the accountee considers the needs of the other. Therefore dualist Vedic philosophy is also interpersonal. This thesis suggests that such accountability should be incorporated into social and institutional roles, on the grounds that this will cultivate sustainable desires and, hence, sustainable consumption patterns. The practicality of this is discussed in the ninth chapter.

This suggestion of institutionalising Vedic accountability is drawn from the explanation of the Vedic social system given by Bhīsmadeva to King Yudhisthira, immediately after the battle of Kuruksetra. On his unusual deathbed, Bhīsmadeva explained to the King how the arrangement of the Vedic social system accounts for the self as different from the material body (Bhaktivedanta Svami, 1987, verse 1.9.26). Although the Vedas contend that the self is different from the material body, they nonetheless acknowledge that, while inhabiting the body, one has to act in the material world - and thus constantly face proposals of sensory indulgence. The Vedas describe that, absent a process of refining one's character, one becomes accustomed to thinking that he is the material body, and that he, rather than God, is the Supreme Enjoyer. Recognising this, Bhīsmadeva explained that the Vedic social system is arranged into several occupational divisions so as to develop detachment for lesser, material forms of enjoyment, while interacting with the world in such a way that one develops attachment for higher pleasures of the self. By utilising his personal talents, qualifications and proclivities to interact with the material energy to serve the Supreme rather than one's own senses, one attains a higher taste. Thus Bhīsmadeva explained the Vedic principles of counteraction by detachment and interaction by attachment. A dualist theory of accountability therefore counteracts material attachment by not attributing any positive value to unnecessary, materialistic goods and services, and encourages interaction with the material energy by recognising the Krishna as the Supreme Enjoyer, so people may attain a higher form of enjoyment. These principles are explained in the following two chapters. 


\section{Chapter Six: Counteraction by Detachment}

The previous chapter established that dualist Vedic philosophy makes a distinction between the self and the material body and that one cannot find satisfaction through the body via the stimulation of the body's senses. Instead, the Vedas assert that complete satisfaction is only obtained through pure, unmotivated service to God, of Whom the living entity is a part of. In a nondualist theory of accountability, Saravanamuthu (2006) explained that ahimsic, or non-violent outcomes can be achieved by basing systems of accountability on the notion of the self as interconnected with the entire ecosystem. This would encourage "reflexive responses" to socio-environmental degradation and thus individuals would consciously modify their behaviour, expectations and values to more sustainable ones (Saravanamuthu, 2006, p. 306). Dualist accountability, on the other hand, seeks to transform behaviours, expectations and values by addressing the needs of the self, for when the self is satisfied one will no longer seek satisfaction through the senses of the body in an unsustainable manner. To address the first research question posed at the beginning of this thesis, this chapter describes how a dualist Vedic theory of sustainable accountability would be constructed to avoid the cultivation of unsustainable patterns of consumption. This is achieved by the dualist method of counteraction by detachment. The first section of this chapter elaborates on the Vedic assertion that one cannot obtain satisfaction through materialistic pursuits. The second explains why such pursuits should be considered unsustainable and then details how dualist Vedic accountability encourages detachment from them.

\section{The Non-Material Identity of the Self}

The Vedas are not alone in asserting that consumerist behaviour injures environmental and societal wellbeing - social and environmental accounting research conducted by Islamic and Buddhist commentators has made similar claims (Kamla et al., 2006; Khan, 1991; Lewis, 2001; Linyanarachchi, 2007). These contentions have also been made from a material standpoint, as Chwastiak and Young (2003) argued that mainstream accounting undervalues the detrimental repercussions of marketing consumerist goods and services, and the negative consequences of promoting and selling them go unmentioned in annual 
reports because this would conflict with maximum profit realisation - a contradiction they attribute to the unequal distribution of wealth and power in capitalist society. They claim that when consumption is seen as an ultimate goal, it creates emptiness and angst within individuals because the fulfilment of consumerist desires is temporary and non-cumulative. The sense of emptiness that follows such consumption, however, only stimulates a craving for more, "leading to a vicious cycle of desire that can never be satiated" (Chwastiak and Young, 2003, p. 542). The current neoclassical regime that mainstream accounting is built upon regards such feelings as externalities and, thus, the reporting entity is not held accountable for them. Annual reports are therefore silent on such matters.

Chwastiak and Young base their arguments on psychological studies of consumerism (Frank, 1999; Huyghe and Ikeda, 1991; O’Sullivan, 1999). In recent decades studies of consumerism reporting similar findings have grown, though, as Lintott (1998) describes, their implications have largely been overlooked in mainstream economics:

“... the view, common to most schools of economics, [is] that consumption is closely related to welfare and should be maximised" (1998, p. 240).

However, beyond the confines of the narrow conventional framework, Lintott claims that the effects of excessive consumerism are becoming common knowledge:

\footnotetext{
"The lack of any simple relation between consumption and welfare seems to be widely acknowledged among non-economists, whether in folklore ('can't buy happiness') or in sociology or psychology, where the motives for consumption are investigated more critically than in economics" (1998, p. 242).
}

Layard (2005), after reviewing psychological research on consumerism, writes that for most Western people, levels of happiness have not increased since the 1950's - the time period over which consumption has increased the most. In America, Britain and Japan, Layard claims people are no happier despite living standards having more than doubled with major increases in real income across 
all incomes. Like other reviewers (Easterbrook, 2003; Frey and Stutzer, 2002; Kasser, 2002; Lane, 2000), he found that once basic human necessities of food, shelter, clothing and the like are met, subjective wellbeing is only slightly affected by income, if at all. Lintott states:

"This literature makes it clear that, once basic material needs are satisfied, people seek in ever growing consumption satisfaction of wants ... which consumption cannot possibly deliver, or only to a tiny minority, and which it may even in fact undermine" (1998, p. 245).

Therefore the Vedas describe that once the needs of the body are met, needs of the non-material self become the priority, which cannot be met by consuming material goods. But lacking knowledge of how to satisfy these needs happiness cannot progress beyond a basic level. Myers and Diener support this:

"People have not become happier over time as their cultures have become more affluent. Even though Americans earn twice as much as in today's dollars as they did in 1957, the proportion of those telling surveyors from the National Opinion Research Centre that they are "very happy" has declined from 35 to 29 percent. Even very rich people - those surveyed among Forbes magazine's 100 wealthiest Americans - are only slightly happier than the average American. Those whose income has increased over a 10-year period are not happier than those whose income is stagnant. Indeed, in most nations the correlation between income and happiness is negligible - only in the poorest countries, such as Bangladesh and India, is income a good measure of emotional well-being" (1996, pp. 70-71).

Others report similar findings, ${ }^{14}$ affirming that above an income required for a basic standard of living, wealth has little or no effect on subjective wellbeing consistent with the Vedic assertion that satisfaction cannot be attained through sensory enjoyment. Some opponents may argue that increased incomes do not necessarily represent more consumerist lifestyles, as some households may have

\footnotetext{
14 See, for instance, Diener, Sandvik, Seidlitz and Diener (1993), Veenhoven (1993) and Wilkening and McGranahan (1978).
} 
needed to provide for more dependents. However, the percentage of Americans who considered themselves happy peaked in 1957 despite consumption per person having more than doubled since then (United Nations Development Program, 1999). ${ }^{15}$ Furthermore, research has found that holding highly materialistic desires is associated with a lack of wellbeing. Diener and Oishi (2000), for instance, found, after collecting value and life satisfaction measures from over seven thousand college students in forty-one different nations, that a strong value on making money was associated with diminishing life satisfaction. Others have reported parallel findings. ${ }^{16}$

To account for this phenomenon of decreasing happiness while sensory stimulus - or even the desire for it - increases, some psychologists (Kasser, 2002; Lane, 2000; Maslow, 1954; Ryan and Deci, 2000) postulate that humans have psychological needs as well as physical needs, and when lacking the former, they try to satisfy themselves through consumption, which leads instead to greater dissatisfaction:

"Just as a person who eats junk food will be less healthy than one who eats many fruits and vegetables, an individual with relatively central materialistic values will have fewer chances to fulfil the needs required for psychological growth and happiness" (Kasser, 2002, p. 27).

As Kasser explains, then, it is not simply that people who are already unhappy focus more on wealth, image, possessions and sensory enjoyment but rather that

\footnotetext{
${ }^{15}$ There are also suggestions that happiness does not increase with rising levels of income because rising living standards also raises the expectations of happiness. Thus although people are happier with more sensory enjoyment, they do not report it. However the same people surveyed over their lifetimes have not become happier despite becoming richer (Easterlin, 2001). Furthermore, when comparing Western industrial countries, the richer ones are no happier than the poorer. In countries that earn more than $\$ 20,000$ per head, additional income is not associated with extra happiness (Layard, 2005). As expectations would not have increased at the same rate across all industrial nations, happiness levels cannot have remained stationary due to rising expectations. Thus, as Kasser (2002) states, psychological research has established that money does not buy happiness.

${ }^{16}$ See, for instance, Ahuvia and Wong (1995), Belk (1984, 1985), Carver and Baird (1998), Cohen and Cohen (1995), Dawson (1988), Dawson and Bamossy (1991), Kasser (2002), Kasser and Ryan (1993, 1996), Mick (1996), Richins and Dawson (1992) and Sheldon and Kasser (1995, 1998, 2001). This research has also discovered that those who hold materialistic goals as central report significantly higher levels of depression and anxiety (Kasser and Ryan, 1993, 1996; Schroeder and Dugal, 1995; Wachtel and Blatt, 1990), more anti-social behaviour (McHoskey, 1999) and narcissism (Roberts and Robbins, 2000).
} 
people lacking satisfaction of their psychological needs take refuge of consumerism. The Vedas agree that people have psychological as well as physical needs, and they add the needs of the non-material self for consideration. When the latter are missing, then seeking satisfaction through materialistic pursuits can never satisfy the non-material self. As the Bhagavad-Gittā describes, kàma - the desire to enjoy through the mind and the senses - is duspürena never to be satisfied, and is analena - burns like fire (Bhaktivedanta Svami, 1989, verse 3.39). The more fuel is applied to a fire, the larger it grows, even though it may appear reduced for a short moment after the extra fuel is added. Similarly, the Vedas enjoin that the more senses are stimulated, the more the desire for sensory enjoyment grows, although it may appear to be satiated initially. As Layard describes:

"One reason why happiness has not risen, despite our high standard of living, is that we get used to the higher standard of living. At first, extra comfort gives extra pleasure. Then we adapt to it and our pleasure returns towards its former level" (2005, p. 154).

Similar to Layard, other psychologists refer to kāma as perceptual adaptation, whereby responsiveness to sights, sounds, odours and other sensory stimulations decrease as people continue to experience them (Schwartz, 2004). As experiences become more familiar, people desire more sensory stimuli to remain feeling content. Easterlin (1995), for example, when investigating the hedonic purchasing power of money, found that with each increment of income people created a new standard to measure themselves against. As Richins and Dawson state, other researchers have found the same trend when examining psychological effects of excessive consumption:

"The lust for goods can be insatiable: the pleasures of a new acquisition are quickly forgotten and replaced with the desire for more. This cycle leads inevitably to dissatisfaction and discontent ... Empirical tests of materialism support this hypothesis" (1992, p. 308). 
Psychological findings therefore confirm the Vedas' claim for the self having needs that cannot be met through sensory stimulus alone. This is consistent with Shearer (2002) and others (Hines, 1988, 1989), who contend that values inherent in accounting reproduce similar values in society, and promote unsustainable consumption patterns. As Ibrahim explains, Western theories of accountability hold materialism as an inherent value and belief, asserting the worldview that matter, "is the primordial or fundamental constituent of the Universe, which is not governed by intelligence, purpose or final causes" (Chapra, 1992, p. 22, quoted in Ibrahim, 2000, p. 22). Certain consequences follow from this:

"...material wealth and sensuous pleasures become the greatest values one could seek or attain. This in turn becomes the basis for the increasing commercial consumer culture in economics and shareholder wealth maximisation concepts in accounting" (Ibrahim, 2000, p. 22).

Similarly, Noreen (1988) states that the teaching of agency assumptions in conventional accounting socially legitimises values of self-interest, greed and opportunism and depicts them as typical human behaviour or as ideals to be striven for.

The Vedas, however, when referring to pleasure and satisfaction, make reference to enjoyment that far exceeds that achieved through materialistic endeavours. From the Vedic perspective, sensory enjoyment is classified only as the temporary cessation of distress. The Vedas regard hankering and lamenting for material things as distresses, and sensory enjoyment is simply the negation of material hankering. Actual satisfaction, the Vedas describe, begins with the freedom from hankering and lamenting for material things (Bhaktivedanta Svami, 1989, verse 18.54). As Caitanya Mahaprabhu prays:

na dhanam na janam na sundarim

kavitām vā jagad-ìśa kāmaye mama janmani janmanīsvare bhavatād bhaktir ahaituki tvayi 
"O almighty Lord, I have no desire to accumulate wealth, nor do I desire beautiful women, nor do I want any number of followers. I only want Your causeless devotional service, birth after birth" (Bhaktivedanta Svami, 1996, Antya-līlā, verse 20.29). Because of His completely selfless service rendered to God in bhakti-yoga, Caitanya Mahaprabhu relished such pleasure that $\mathrm{He}$ considered all material forms of happiness to be insignificant. Vedic philosophy agrees that humans have physical and psychological needs but asserts that they have spiritual needs as well. Without the knowledge that they are not the material body, and thus without knowledge of their spiritual needs, living entities seek fulfilment through materialism, and thus fall short of Vedic standards of happiness and wellbeing. Therefore, while Chwastiak and Young (2003) reveal that annual reporting is silent on the consequences of marketing consumer goods, from the viewpoint of dualist Vedic philosophy, the silence is louder than Western commentators realise.

\section{Accounting for the Non-Material Identity of the Self}

The previous section established that by indulging the material senses of the body one cannot achieve the satisfaction of the self. However, lacking knowledge of what is actually fulfilling to the self, one has no option but to revert to the gratification of the six senses, which, from the Vedic outlook, include the mind. Since the mind is included as a sense organ, from the Vedic point of view there are both gross and subtle aspects to materialism. In its subtle forms, the desire for sensual enjoyment is manifest as philosophical speculation, and in its more gross forms, material desires often take the form of what is commonly called consumerism. Because material forms of enjoyment are intended to satisfy the self separately from the Supreme, they are ultimately unfulfilling. Chwastiak and Young (2003) state, consumerism leads to a cycle of desires that can never be satiated. Similarly, the Bhagavad-Git $\bar{a}$ describes that the desire to enjoy through the senses is duspürenanalena ca-never satisfied and burns like fire (Bhaktivedanta Svami, 1989, verse 3.39). Ecologists have therefore stated that excessive consumption is a major threat to the sustainability to the world's environmental and social systems (Commoner, 1990; Daly, 1992; Durning, 1992; Goodland, 1992). Thus many thinkers advocate reducing the desire for gross forms of materialism. 
The Vedas are also concerned with reducing material desires, and their method is to provide the opportunity to experience enjoyment far superior to material sensory pleasure. The Vedas readily acknowledge that more sustainable consumption patterns than those currently present in Western culture can be achieved by accounting, for instance, with Saravanamuthu's (2006) methods for reducing time and space fragmentations. However, without considering the self as different from the material body there is no chance of satisfying the self. Dualist accountability therefore addresses the desire issue, not by attempting to quell desire altogether, but by encouraging desires to be redirected at a satisfying, and thus sustainable ends. Thus dualist Vedic accountability is concerned with accounting to Śrī Krishna as a higher principal and part of one's responsibility to Krishna lies in not misleading other living entities to pursue lesser, exploitative forms of enjoyment. This also helps to achieve sustainable patterns of consumption, for, as it is seen, one cannot extinguish a fire by adding more fuel, but only by ceasing to add fuel.

As this section will explain, dualist accountability does not recognise value for activities that cultivate material desires. In the Vedas this is called vairāgya - detachment. In either contemporary or traditional Vedic culture, detachment from material desire and rāga - attachment to higher forms of enjoyment - are encouraged. Following Lintott, then, before any theory of accountability can be regarded as sustainable, it must first address detachment from material desire:

"Reducing the scale of rich economies requires not only an increase in the efficiency with which resources are used, but also identifying those goods and services which don't need to be produced at all. Such an endeavour is central to an economics of sustainability" (1998, p. 246).

Dualist Vedic accountability does not recognise value for the production, promotion or sale of consumerist goods and services that only stimulate the mind and senses. Thus intangible assets, such as goodwill and brand names would not be recognised when established for increasing consumerism. Similarly, assets would not be acknowledged where they contributed solely to the production of consumerist goods. Furthermore, instead of recognising a positive value for the 
sale of consumer goods, environmental and social costs would be taken into account as previous commentators have suggested. Smark (2006), for instance, identifies that the indirect costs of schizophrenia outweighed its direct costs by a ratio of two-to-one. Because such indirect costs went unmentioned in the Australian Public Health Sector's financial statements, Smark appealed for a more social form of accountability to overcome the silencing of such costs. Peace likewise appealed for the inclusion of other human welfare considerations:

"The preparation of a monthly electric bill from a fossil fuel burning utility does not take into account the non-commodity costs associated with the impact of fossil fuel consumption on the environment, human health and other quality of life considerations (Rutherford et al., 1998). Accountants could develop procedures to calculate cost data on human health and quality of life effects from pollution" (2006, p. 793).

Commentators such as Chwastiak and Young (2003) have identified many costs that are silenced in mainstream accountability - costs to the environment, the costs of treating animals as commodities, the costs of war and the costs of consumerism, but the Vedic paradigm identifies additional costs that go unheard due to an unawareness of their existence. The karmic consequences to actions are an example of an additional cost bought to light by the Vedic literature. Saravanamuthu (2006) describes the Vedic Law of Karma as the principle that every action has a consequence. Even materially, every action has an equal and opposite reaction - this is the assertion of Newton's Third Law of Motion. As the fifth chapter described, though, from the Vedic perspective, the universe is comprised of material and conscious forms of energy. According to the Vedas, laws of action and reaction govern the conscious form of energy as well as material forms as. This is declared by Krishna in the Bhagavad-Gītāa, where He states: bhüta-bhāvodbhava-karo visarah karma-samjñitah - "Action pertaining to the development of the material bodies of the living entities is called karma, or fruitive activities" (Bhaktivedanta Svami, 1989, verse 8.3).

An appreciation of the Vedic Law of Karma requires an understanding of the dualist perception of the material body. According to dualist philosophy, the body is a concentrated receptor of various nerves and senses awarded to the 
living entity so that he may experience the reactions of his previous life's activities. ${ }^{17}$ Even a superficial observation of the material body will reveal that it is predominantly a digestive system that supports the functioning of six senses (smell, taste, sight, touch, hearing and the emotions of the mind) which experience various forms of pleasure and distress. As Devamrita Svami explains:

"The Vedic science of transmigration tells us that in the present human body we are undergoing the reactions from deeds of our past life. From that perspective, "body" means the embodiment of reactions to past karmic activity. Meanwhile, we are busy acting again - business as usual. That means, while we undergo our past karma, we simultaneously pile up new karma, which will greet us in our next birth. When the soul moves from the dead body to the new one, it is actually moving from a withered field of spent karmic reactions to a fresh field of ripe ones" (2002, p. 223).

The Vedas enjoin that past karmic reactions that are experienced as enjoyment or suffering cannot be fundamentally altered through material means such as social, political, or economic measures. Therefore, from the dualist perspective, there is little worth in striving for material enjoyment that is already predestined, or in trying to repel suffering that is also sure to come - hence another reason why dualist accountability does not recognise value for activities ultimately intended for sensory enjoyment and overly-comfortable living. Instead, value is attributed to activities that are not material and are thus non-karmic - those intended for the satisfaction of the Supreme. As the Śrimad-Bhāgavatam states:

tasyaiva hetoh prayateta kovido na labhyate yad bhramatām upary adhah tal labhyate duhkhavad anyatah sukham

kālena sarvatra gabhīra-ramhasā

"Persons who are actually intelligent and philosophically inclined should endeavor only for that purposeful end which is not obtainable even by wandering

\footnotetext{
17 A review of the reincarnation literature is not within the scope of this thesis, but interested readers may consult the works of Stevenson $(1974,1987,1997)$.
} 
from the topmost planet [Brahmaloka] down to the lowest planet [Pātāla]. As far as happiness derived from sense enjoyment is concerned, it can be obtained automatically in course of time, just as in course of time we obtain miseries even though we do not desire them" (Bhaktivedanta Svami, 1987, verse 1.5.18). In addition to recognising the social and environmental consequences of producing and selling consumerist goods, then, dualist Vedic philosophy also identifies the costs for marketing goods that accrue further karmic reactions. As the seventh chapter will describe, value is instead placed on activities intended for the satisfaction of the Supreme, which are called akarma, that do not produce karmic reactions (Bhaktivedanta Svami, 1989, verse 4.18).

Other religious contributors to the social and environmental accounting literature have expressed opinions on consumerism that run parallel to the dualist Vedic perspective. Anjum (1996), Khan (1991) and Lewis (2001) agree that Islamic scriptures prescribe a low-cost lifestyle based on simple living and a balanced pattern of consumption. They claim that spending patterns in Islamic culture do not follow the excessive consumerism typical of Western societies. Harahap, also commenting from an Islamic viewpoint, explains that the sustainability of human wellbeing as the focus of socio-economic development "requires economic organisation of life and thought, an ethical accounting of the flows of income and cost in the light of ethical considerations of production, consumption and use" (2006, p. 40). As Kamla et al. state:

"The Islamic perspective on the business organisation is suggestive of accountings ... covering the legitimacy of business trade (a kind of monitoring of the ethics of business activity, akin to ethical investment processes: harmful trade, when understood as such, being forbidden, Abdel Haleem, 1998, p. 8), whether the business is fulfilling its obligations to help the needy (it is an Islamic principal that wealth be shared in this context) and the negative impacts of the organisation upon the environment as well as the positive" (2006, p. 259).

Similar to its Vedic counterpart, then, Islamic systems of accountability value goods and services according to their worth as prescribed by the Islamic scriptures, namely the Quran and the Sharia (Chowdhury, 1999; Lewis, 2001; Pomeranz, 1997). Such value is attributed via relevance principles, such as 
materiality and decision usefulness. Lewis (2001), for instance, states that accounting information in an Islamic framework is considered relevant if it is related to Sharia requirements, and Pomeranz (1997) explains that decision usefulness from the Islamic point of view requires enrichment through the addition of Islamic ethical imperatives. Lewis claims that Islamic accountability impresses this principle across all accounting concepts:

"Under Islam, the elements of financial position would include all items which are subject to financial evaluation, assets, liabilities and the residual benefits, based on the Holy Qur'an" (2001, p. 33).

Thus it can be seen that the concept of including social, environmental and spiritual costs to encourage detachment from detrimental activities is not limited to a dualist Vedic theory of accountability, but has been suggested by other commentators. The primary Vedic method of promoting detachment from material enjoyment, though, is through providing the facility for $r \bar{a} g a-$ attachment to higher spiritual taste, as is explained in the following chapter. 


\section{Chapter Seven: Interaction by Attachment}

Despite an expanding literature demonstrating that happiness does not increase with the consumption of material goods above a certain threshold, relatively little research has focused on how to motivate people to alter their lifestyles so they consume few resources (Brown and Cameron, 2000). Some have suggested that this will require a fundamental shift from self-interested, consumer-oriented values to a pro-social value orientation that motivates and fosters development and acceptance of economic and social policies aimed at curbing consumption levels in the interest of environmental sustainability. However, there has also been little systematic research on how to instil such values in society. In the sustainable consumption literature, though, Brown and Cameron (2000) have drawn on the work of Stern, Dietz and Guagnano (1995), to propose a behavioural model delineating the role of social values in guiding belief systems, attitudes, intentions, and behaviour. Brown and Cameron suggest that could provide a theoretical and empirical foundation to organise and evaluate economic, social, and psychological factors that determine consumption patterns. A modified version is reproduced below (Figure 1).

As Brown and Cameron (2000) recount, social institutions (such as national laws, systems of accountability, market and incentive structures, educational systems, community structures, and social networks) foster specific social values that help construct general belief systems or worldviews regarding specific life domains, such as political belief systems or views about the environment. Such worldviews provide a picture of reality that filters new information, and channels and constrains the development of attitudes and beliefs about specific issues that in turn determine intentions and decisions to engage in certain behaviors. Brown and Cameron explain that behavioral commitments and intentions also are influenced by prevailing social norms and by the development of specific plans or strategies for engaging in behavior. Behaviors can often significantly alter the structure of social institutions, and thus these effects filter through the system (Brown and Cameron, 2000). 


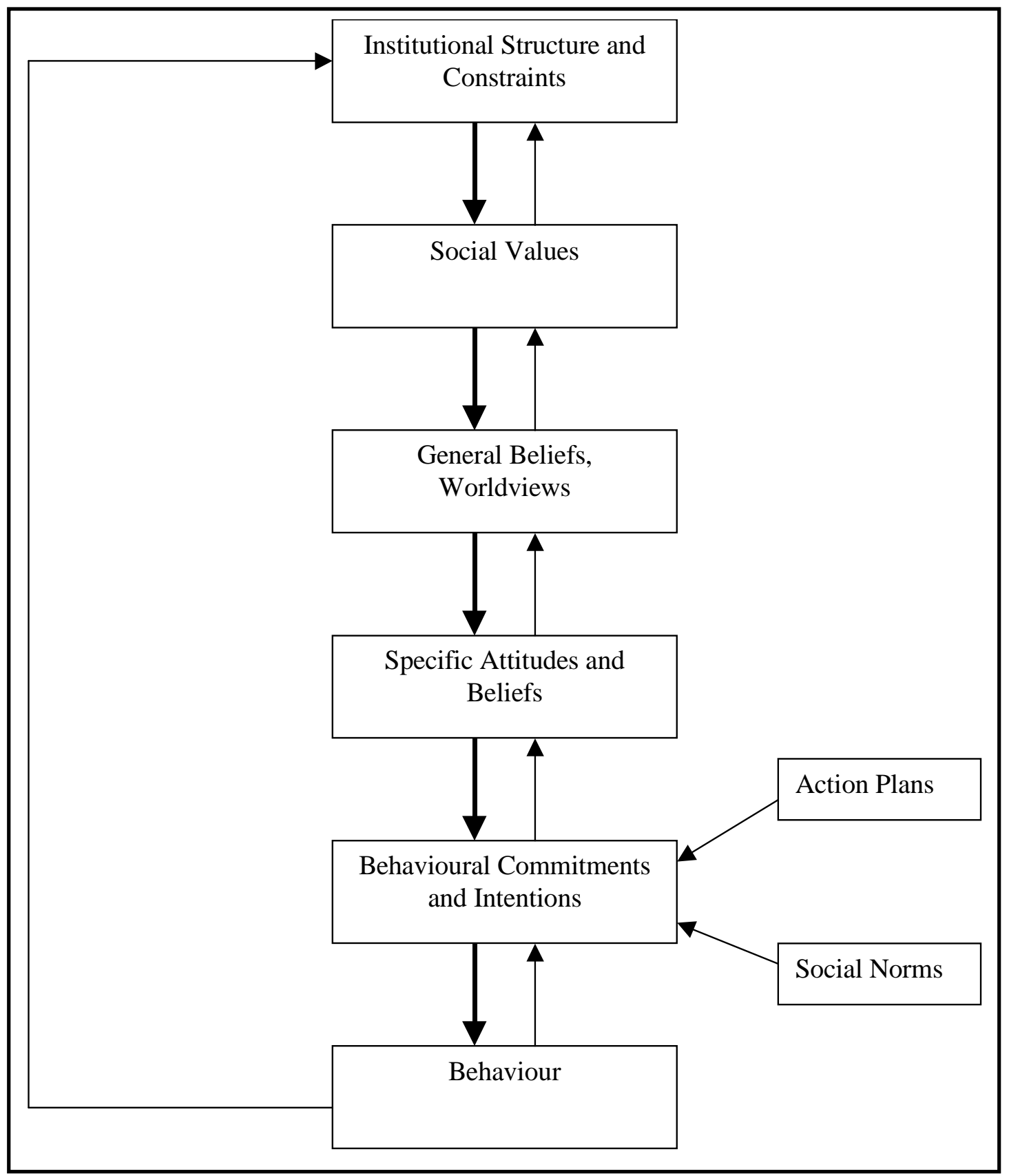

Figure 1. The Roles of Institutional Structure, Social Values, Worldviews, Attitudes, and Intentions in Determining Consumption Behaviour ${ }^{18}$

According to this model, higher-level structures are more stable, less susceptible to transient influences, and more resistant to change relative to lower-level structures (Stern, et al., 1995). Worldviews, for example, are more stable over time and less susceptible to change as a result of moods, propaganda messages or social influences. Moreover, higher-level structures have a greater influence on

${ }^{18}$ Adapted from Stern et al. (1995). 
lower-level structures than lower-level structures have on them (thus the bold downward-pointing arrows). For instance, a shift in a worldview (towards a proenvironmental worldview, for example) will have a greater impact on specific attitudes (positive attitudes toward paper made out of recycled material, for example) than an attitude shift will have on worldviews (Brown and Cameron, 2000). Within this framework, then, consumerist values are seen as a product of the structure and constraints of the prevailing socio-economic and accounting system, including the incentive structure advanced by the market and promotional messages. This consumerist value orientation, can serve as the organising principle for a general worldview or system of beliefs regarding ecology and the environment.

When considering the prevalent consumerist orientation within the context of this behavioural model, it becomes apparent why individuals often do not support consumption reduction policies. Efforts to reduce consumption levels through penalties, taxation, boycotts and voluntary conservation of resources, have usually met only limited success (Aronson, 1990; Sagoff, 1988). Brown and Cameron argue that such programs generally attempt to motivate the public to engage in efforts to reduce consumption by changing attitudes about issues, such as choosing products made from recycled materials. Although consumers recognise and understand the information about the environmental benefits, these perceptions generally have only a small impact on decision-making. Instead, their environmental decisions appear to be determined primarily by perceptions of personal and monetary costs (DeYoung, 1989; Cameron, Brown and Chapman, 1998), a pattern consistent with a consumerist value orientation. As Stern et al. (1995) note, these programs will have little long-term impact because they focus on changing specific attitudes and beliefs about individual issues while ignoring the general worldviews, values, and institutional structures that provide the context for these attitudes. Attempts to induce change at either the level of specific attitudes and beliefs or commitments and intentions will fail if such changes are inconsistent with more stable worldviews and general cultural values. This theoretical model therefore suggests that interventions aimed at reducing consumption will be most effective if they can bring about higher-level changes in the socio-economic-cognitive system - by changing cultural values and worldviews. 
To bring about a change in cultural values and worldviews, Brown and Cameron (2000) state that two essential conditions are necessary - challenging the consumerist value orientation and promoting an alternative value orientation. This thesis argues that a dualist Vedic system of accountability meets both of these conditions because it aims to provide individuals with a genuine spiritual experience instead of material luxuries. Such spiritual experiences are provided because the system recognises the performance of bhakti-yoga. Brown and Cameron state that any viable, alternate value orientation to consumerism must promote a pro-environmental belief system and, in turn, a willingness to support and adopt both voluntary and legislative efforts to reduce consumption levels. Bhakti-yoga can provide such a value orientation because by achieving a higher taste through satisfying the Supreme, the enthusiasm for unsustainable, materialistic pursuits is transformed into the enthusiasm for satisfying the desires of the Supreme. Properly supervised and applied, bhakti-yoga is successful at altering social values and worldviews because it provides a genuine experience of a spiritual reality which shatters the worldview that matter is the summum bonum of the universe, and that sensory pleasure is the highest goal one can aspire for.

Instead of attributing a positive value to items and endeavours intended for sensual enjoyment, then, dualist Vedic accountability would recognise value in endeavours meant for the satisfaction of the higher principal Krishna. This chapter explains how it can attribute value to such activities in the following section discussing the concept of a higher taste. The latter sections describe, with reference to Vedic literature, what activities constitute as pleasing to God, and how they would be recognised as valuable in a system of accountability.

\section{A Higher Taste}

Some spiritual paths, such as Buddhism and Taoism, stress the need to eliminate much of the desire for sensory enjoyment to achieve sustainable lifestyles and consumption patterns. These religions derive this objective from a conception of the self that is null or void:

"Buddha prescribed the eight-fold middle way consisting of right views, resolve, speech, conduct, livelihood, efforts, mindfulness and concentration to attain 
freedom from desires. Ho (1995) points out that at the heart of Buddhism is the metaphysical position that denies the ontological reality of the self. This view of freedom is also prominent in Taoism. Lao Tzu, the founder of Taoism, wrote "Let people hold on to these: Manifest plainness, embrace simplicity, reduce selfishness, have few desires" (quoted in Bishop, 1985, p. 450)" (Velayutham and Perera, 1996, p. 69).

Even outside of religious paradigms, some commentators suggest that, in the interests of stemming consumer culture, economics should adjust its conception of welfare so that only material needs are valued instead of endless wants (Kronenberg, 2007; Lintott, 1996, 1998). Dualist Vedic philosophy, however, does not maintain that the elimination of the desire for pleasure altogether is possible, especially in Western countries, where the conception of one's freedom, as described by Velayutham and Perera, is liberation from external constraint, "so that he or she can make a choice and proceed to satisfy his or her own desires" (1996, p. 69). As Krishna explains in the Bhagavad-Gìtā: na hi kaścit ksanam api jātu tistaty akarma-krt - “... no one can refrain from doing something, not even for a moment" (Bhaktivedanta Svami, 1989, verse 3.5). Bhaktivedanta Svami therefore writes that to restrict one from sensory enjoyment is akin to restricting a diseased person from certain eatables: "The patient, however, neither likes such restrictions nor loses his taste for eatables" (1989, p. 148). Buddhist commentators concede this, even though they advocate the eightfold middle way to attain freedom from desires:

"However it is stated that human nature is such that people choose happiness over pain. Accordingly, people tend "to seek pleasure or happiness and recoil from pain or a source of unhappiness" (Majjhima Nikaya, cited from Jayatilleke, 2000, p. 55). Thus contrary to some misconceptions that Buddhism is gloomy and renounces all pleasures, seeking happiness is not condemned (Jaytilleke, 2000). What is encouraged is a change of focus so the seeking of happiness is not harmful to one's moral and intellectual development nor, more importantly, does it preclude others' search for happiness. The difficulty of pursuing such action is obvious" (Liyanarachchi, 2007, p. 24 [Emphasis added]). 
Therefore, as Brown and Cameron (2000) state, researchers and environmental experts tend to reach an impasse here when theorising about how to reduce overconsumption. Rather than eliminating desires altogether, though, dualism advances that desire should be transferred from sensory enjoyment to the desire to satisfy the Supreme.

Druhl et al. (2001) demonstrate that Vedic philosophy has a powerful effect on its practitioners and their surrounding environment, especially in its ability to withdraw the living entity from unsustainable desires. As previously described, the TM paradigm that Druhl et al. analyse is located in non-dualist Vedic philosophy, and hence does not accurately represent the dualist philosophy. Dualism asserts that its practitioners experience a higher taste because their spiritual reality is personal rather than impersonal. Thus enjoyment in dualist philosophy is significantly greater than that which non-dualist schools refer to. ${ }^{19}$ Therefore the examples that Druhl et al. provide will only partially illustrate the dualist conception of a higher taste.

In any case, they recount that the founder of the non-dualist Maharishi Vedic Science predicted that in cities where approximately one percent of the population practiced Transcendental Meditation techniques, the quality of life as measured by crime and accident rates, amongst others, would improve significantly. Follow-up studies have tested these claims, comparing the changes in the FBI Uniform Crime Report Index for twenty cities where one percent of the population practiced TM techniques with a control group of twenty cities without the one percent level of practitioners. The former showed an average decrease in crime of twenty-two percent in 1973, compared with an increase in the latter cities (Dillbeck, Landrith and Orme-Johnson, 1981). A larger scale analysis of the relation between TM practice and crime reduction was undertaken in 160 USA cities from 1972 to 1978. It compared crime trends to those projected from a linear regression from 1964 to 1971, finding that the increased percentage of TM practitioners was a leading indicator for decreases in the crime trend - accounting for a reduction of about eighteen percent (Druhl et al., 2001).

\footnotetext{
19 Sukadeva Gosvami testifies to this in the Śrimad-Bhāgavatam, stating: madhudvitsevānurakta-manasām abhavo 'pi phalguh - "Krishna is so attractive that one can give up all desirable things for His sake. Indeed, even [non-dualist] liberation is considered insignificant for those whose minds are attracted to the loving service of the Lord" (Bhaktivedanta Svami, 1987, verse 5.14.44).
} 
Druhl et al. have also claimed that such practices would positively effect the physical environment and have identified TM as a solution to the pressing environmental problems currently facing the world. Thus, even through nondualist Vedic meditative techniques, a comparatively small group of practitioners can significantly influence an area as large as a city.

The concept of a higher taste is not unique to the Vedic paradigm, but has been advanced by commentators from the Islamic paradigm as well. As will be described later in this chapter, Islamic accountability requires the Muslim to make certain sacrifices for societal-wellbeing to please God. As Anjum explains, such sacrifices also have a positive effect for the contributor themselves, and thus are recognised as a unique type of welfare by Islamic economics:

“... a Muslim consumer experiences an increase in his own utility whether he consumes goods himself or offers goods he likes for himself to the other human beings for consumption. The marginal utility of a person ... goes on diminishing if he consumes more and more ... because the law of diminishing marginal utility applies when anybody consumes additional material goods for himself. However, the marginal utility of a Muslim ... goes on increasing if he offers more and more of goods to other in the way of Allah because the law of increasing marginal utility applies due to ever-increasing spiritual satisfaction and reward from Allah associated with offering more and more material goods in the way of Allah" (1996, p. 68).

Thus the concept of a higher taste is also acknowledged in Islamic economics. Dualist Vedic philosophy describes the means of attaining a higher taste by being held accountable to Krishna as a higher principal, whereby the consumerist propensity is subdued. The highest platform of sustainability, then, is the desire to satisfy Krishna - not an artificial attempt to abolish or lessen desires, for such efforts are neither satisfying nor sustainable. What constitutes God's pleasure and how to incorporate this into systems of accountability is described below.

\section{Real Wealth}

Kasser (2002) suggested that people follow unsatisfying consumerist lifestyles because their psychological needs have gone unfulfilled. The Vedic position 
concurs, and further asserts that people have spiritual as well as psychological needs that must be met for them to be completely satisfied. Due, however, to a lack of knowledge of his spiritual needs, man resorts to materialism. This thesis has presented that one can attain full spiritual satisfaction through the execution of the bhakti-yoga, but this is not something that can be done whimsically. As Devamrita Svami explains:

"It's not that anything you construe as wholesome and good is transcendental service to Krishna. Genuine love means that you inquire from the beloved what is most pleasing. That is true in the temporary, shadowy romances of the relative plane as well as in the eternal, lawless devotional love of the spiritual plane. Any ordinary, tiny living entity feels quite competent to explain what supposedly gives him or her satisfaction. Certainly Infinite Complete - Krishna, the source of all living entities - can perfectly do so. ... Through the most comprehensive spiritual texts, Bhagavad-Gìtā and Śrimad-Bhāgavatam, and through a chain of spiritual teachers who exemplify these texts, Krishna instructs us how to give genuine pleasure to Him, the source of everything" (1996, p. 41).

In the Bhagavad-Gìtā, Krishna states that $\mathrm{He}$ is pita - the father - of sarvayonisu - all species of life (Bhaktivedanta Svami, 1989, verse 14.4). Naturally a father is concerned for the welfare of his children, yet without knowledge of his spiritual needs, one cannot experience a level welfare higher than the maintenance of his temporary body and mind. Krishna therefore states in the Bhagavad-Gìtà that anyone who tries to teach others of their spiritual needs is acting in the way that is most pleasing to Him (Bhaktivedanta Svami, 1989, verse 18.69). Thus the Vedas describe that God is a person Who becomes inclined to those who inform other living entities of their spiritual nature and spiritual needs, and thus the dualist Vedic paradigm is deeply concerned with responsibility for the other. Attempts to spread the philosophy and practice of bhakti-yoga are therefore activities that are considered real wealth in a dualist system of accountability. As Brown and Cameron state, this principle of informing others of the particulars of sustainable living is consistent with the behavioural model of Stern, et al. (1995) for determining consumption patterns: 
"Individuals need specific plans and strategies for reducing resource consumption. As research in other social domains reveals, simple dissemination of information may be sufficient to change attitudes, but it is not sufficient to induce behavioral change (Hines et al., 1987; Leventhal and Cameron, 1994). Individuals also need specific guides and strategies for reducing consumption of resources and for attaining a lifestyle of 'voluntary simplicity.' Ideally, these guides will not only provide realistic and specific suggestions, but they will also use role models to provide salient demonstrations that these techniques are effective and that this alternative lifestyle is, in fact, a satisfying and rewarding one" (2000, p. 37).

Because bhakti-yoga stresses the teaching of sustainable lifestyles to others, it also fulfils Brown and Cameron's criteria for a viable alternative to a consumerist value orientation. Furthermore, if the living entity differs from the body it is consistent that he should learn of the needs of the self. As Bhaktivedanta Svami states, much emphasis is placed on education pertaining to the body and the mind and how to maintain them but none on understanding the self as a part of God:

"Generally, people are not educated in this confidential knowledge; they are educated in external knowledge. As far as ordinary education is concerned, people are involved with so many departments: politics, sociology, physics, chemistry, mathematics, astronomy, engineering, etc. There are so many departments of knowledge all over the world and many huge universities, but there is, unfortunately, no university or educational institution where the science of the spirit soul is instructed. Yet the soul is the most important part of the body; without the presence of the soul, the body has no value. Still people are placing great stress on the bodily necessities of life, not caring for the vital soul" (1989, p. 450).

As Bhaktivedanta Svami (1989) further describes, to inform others of their spiritual needs is the greatest philanthropic activity. Many religious and nonreligious commentators advocate forms of economics and accountability that incorporate concerns for the material wellbeing of the other. As explained above, 
the Vedas encourage bodily and mental health, but they also assert that concerns for spiritual health must be present because the real identity of the self is spiritual. To have compassion only for the dress of a drowning man is never considered adequate from the material standpoint. Similarly, responsibility only for the body, the dress of the self, is inadequate according to dualist Vedic thought. To be accountable to the other, one must recognise that both he and others are parts of God, and will be fully satisfied only when engaged in the service of the God. Hence dualist Vedic accountability recognises the value of efforts to spread the philosophy and practical application of bhakti-yoga.

In either traditional or contemporary Vedic society, the communication of Vedic moral principles is a fundamental part of the social structure - as Kanagasabapathi describes, in ancient India, "ethical principles and higher values were taught and basic norms were advocated in society" (2007, p. 579). Moral principals were taught by a class of intellectuals called brāhmanas, who were thoroughly conversant with the Vedas, and whose full-time duty it was to guide the rest of society in their dharma (moral and religious principles) (Iyer, 1999). Since it was the full-time duty of the brāhmanas to know and teach religious principles, the rest of the social classes would support them with charitable donations - as Iyer describes, "Ancient India was notable in the practice of danadharma (or the law of gifts) that stipulated giving ceremonial and ritual gifts to Brahmins and temples" (1999, p. 107). As Gupta (2007) further explains, before the third decade of the nineteenth century, merchant charity in India was largely given to religious organisations. However, since one qualification of a real brāhmanas is damah - self-control (Bhaktivedanta Svami, 1989, verse 18.42) whatever charity the brāhmanas did not need above the minimal requirements of the body, they would give to the materially impoverished. ${ }^{20}$ Real brāhmanas never accept a salary - and in this way their teachings are not materially motivated or subject to bias. Thus both ancient and contemporary Vedic societies support a class of people who teach Vedic principles and guide the rest of the

\footnotetext{
20 As Saravanamuthu (2006) describes, Svami Vivekananda argues that religious knowledge should be the subjected to the same methods of investigation as secular knowledge, because in the past the Vedas have been associated with religious rituals that have been used by the priestly (brähminical) class to exploit the masses in India. Therefore this thesis makes reference to qualified brähmanas - those who genuinely possess the qualities of self-control and religiousness.
} 
population in the needs of the self. By giving charity and support to the intellectual brāhmana class, other social classes recognised God as the Supreme Enjoyer, rather than themselves. Thus they acted in their constitutional position as servants of God.

Chanakya Pundit, a Brahmin intellectual who wrote the Arthaśāstra - an economic scripture - approximately two thousand three hundred years ago in India, described the role of brähmanas in the ancient Vedic society. Chanakya Pundit himself exemplified many characteristics of a brāhmana as described in the Vedas - although he was the advisor to the King, for instance, he did not accept a salary and lived in very humble conditions. His economic scripture, 'Arthaśāstra' can be translated as meaning The Science of Material Gain. ${ }^{21}$ It is one of the world's oldest treatises on the economic administration of a state and is, supposedly, the first to describe aspects of accounting (Matessich, 1998). Extremely comprehensive, it provides guidelines for efficiently managing an aristocratic economy, discusses the ethics of economics, and explains the duties and obligations of a king. As wealth was vital to the state, the Arthaśāstra contains numerous accounting principles and concepts, which some commentators have likened to their modern day equivalents (Mattessich, 1998; Sihag, 2004; Bhattacharyya, 1988). The author, Chanakya Pundit, was not a Vaisnava however, and therefore, whilst his Arthaśāstra is a useful reference point, it cannot provide an exact working model. Nonetheless, Chanakya Pundit indicated that the societal growth in knowledge of moral principles - dharma depended upon "knowledge-creating workers" (brāhmanas), income, and existing knowledge (Sihag, 2007, p. 21). Sihag drew the following equations from Chanakya's descriptions:

$$
\mathrm{H}_{0}=\Delta \mathrm{H} / \Delta \mathrm{t}=\mathrm{LH}+\mathrm{H}+\mathrm{Y}
$$

In Chanakya's formula above, $\mathrm{H}_{0}$ is the growth in all disciplines of knowledge, $\mathrm{LH}$ are the knowledge creating workers (brāhmanas), $\mathrm{H}$ is existing knowledge

\footnotetext{
21 'Artha' translates to wealth and 'śästra' means scripture, or science. However, as Kautilya (Chanakya Pundit) uses it in this context, artha has much broader significance than merely wealth. The material wellbeing of individuals is a better description (Rangarajan, 1992). Hence, The Science of Economics or The Science of Material Gain is a more accurate translation.
} 
and $\mathrm{Y}$ is income. ${ }^{22}$ Sihag claims that Chanakya Pundit thought a determinant of $\mathrm{Y}$, income, was $\mathrm{HE}$, "the knowledge of economic principles and accounting methods" (2007, p. 21). The formula he gives for income, then, is:

$$
\mathrm{Y}=\mathrm{A}(\mathrm{GG}, \mathrm{HE}, \mathrm{M}) * \mathrm{~F}(\mathrm{~K} \mathrm{~L})
$$

Here GG is Good Governance. He, as mentioned, is the knowledge of economic principles and accounting methods. $\mathrm{M}$ is ethical conduct - adherence to dharma - and $\mathrm{F}(\mathrm{K} \mathrm{L})$ is the production factor. $^{23}$ Since economic principles and accounting methods helped create income that was a factor of society's knowledge of their dharma, it can be asserted that Chanakya Pundit did hold a place for accounting in Vedic civilisation and the promotion of dharma. He did not specifically identify income as a relevant factor to the creation of knowledge but the existence of the intellectual class depended on support from Y, income per capita:

"With the coming of an agricultural economy, there came also the promise of economic surplus - the production of goods and services in excess of what was needed for survival. This is the condition of civilisation: the possibility of supporting a culture-creating class of professionals" (Drekmeier, 1962, p. 105, quoted in Sihag, 2007, p. 21).

Thus it can be seen that brähmanas, or spiritual intellectuals, are the keystones to Vedic accountability and sustainability, for they can give others access to a higher taste.

\section{Accounting for the Pleasure of the Supreme}

It is evident from the previous section that, by recognising Krishna as a higher principal, dualist Vedic accountability makes specific recognition of two items the donation of charity to brāhmanas engaged in teaching Gaudīya-Vaisnava philosophy, and the endeavour to spread the philosophy and practice of bhakti-

\footnotetext{
${ }^{22}$ Adapted from Sihag (2007, p. 21).

${ }^{23}$ Adapted from Sihag (2007, p. 21). It should also be noted that Sihag himself neglects to define what the $A$ stands for in the above formula.
} 
yoga under the guidance of qualified brähmanas. Such activities, according to Brown and Cameron, are required to install a culture of sustainability:

"It is also essential to foster appropriate worldviews about environmental conservation [in order to promote pro-social and pro-environmental value orientations]. To do so, it is important to disseminate information regarding environmental principles and values in schools, the media, popular books, and the community at large" (2000, p. 36).

It has been described that when accounting to a higher principal, dualist accountability would generally be contractual - though contractual accountability is not always necessary. As seen in Laughlin's (1996) analysis of the Church of England, accountability was communal because there was a high degree of trust between principals and agents. In a contemporary Vedic society, then, it might be seen that amongst brahminically inclined persons with some practical realisation of their non-material identity, accountability would be structured in a more communal way. Accountability of a contractual nature, however, would usually be required where principals and agents have no realisation of their identity as separate from the material body, and are therefore unaware of their common interests, or how to fulfil them. Furthermore, for those with little jũana and vijñāna - knowledge and realisation - of the Vedic paradigm, decisions must be made upon information attained via sense perception. However, the third chapter has already pointed out the fallibility of knowledge obtained thus. Therefore, without a solid understating of the Vedas, there is the need for contractual forms of accountability because of the potential for conflicting values between principals, agents and the higher principal. Similar thoughts exist in Islamic accountability:

... man's knowledge about himself as well as about the universe is so limited and imperfect, due to his inherently limited observational and intellectual faculties, that his eyes can not see beyond a certain limit even in front of him.... In this situation man cannot be a rational person if he relies only on his personal limited knowledge. Rationality logically demands that man should behave on the basis of flawless sets of full information and instructions ... This axiom is received through the institution of Risalah from Allah Who is the Only One 
possessing perfect information. On the basis of limited wisdom, man cannot judge with certainty whether a particular thing is good or bad for him. ... Fortunately, the institution of Risalah by informing mankind about Halal (permissible) and Haram (prohibited) goods, services and activities, provides to mankind in general and to Muslims in particular, a perspective of certainty about the consequent usefulness or harmfulness of an issue or activity or a commodity on the basis of principle of dominance of a good's utility over disutility" (Anjum, 1996, pp. 70-71).

Because it draws upon scripture for these reasons, it is seen that Islamic accountability, similar to its Vedic counterpart, values particulars according to Islamic injunctions:

"The concept of goods is also different in Islam. In Islam goods are bounties bestowed by God upon mankind. According to the Holy Qur'an, the consumable goods are those which attribute moral and ideological values to them (mankind). ... According to Islam, consumer goods are useful, beneficial consumable materials whose utilisation brings about the material, moral and spiritual betterment of the consumer. Things which are not useful and prohibited in Islam are not goods in the Islamic sense. In capitalism goods are those which are exchangeable. But in Islam goods are those which are exchangeable and morally useful" (Chowdhury, 1999, p. 44).

Because of the fallibility of sense perception, dualist Vedic accountability requires that a reporting entity describe how it is contributing to a culture of sustainability by making endeavours for the teaching of bhakti-yoga. In this way, dualist Vedic accountability allows people to utilise their natural tendencies and proclivities to advance a pro-social and pro-environmental value orientation.

By the direct teaching of bhakti-yoga, one simultaneously attains a higher taste and the experience of a higher transcendental reality, even having done nothing to gratify his senses. Thus, under dualist accountability there is the incentive for the inferior, material energy to be used for a spiritual purpose consistent with the philosophy of acintya-bhedābheda-tattva. As described, this use of the material energy is called interaction by attachment. Bhaktivedanta Svami states: 
"Every endeavor requires land, capital, organization and labor. Just as in business one requires a place to stay, some capital to use, some labor and some organization to expand, so the same is required in the service of Krishna. The only difference is that in materialism one works for sense gratification. The same work, however, can be performed for the satisfaction of Krishna, and that is spiritual activity. If one has sufficient money, he can help in building an office or temple for propagating Krishna consciousness. Or he can help with publications. There are various fields of activity, and one should be interested in such activities. If one cannot sacrifice the results of his activities, the same person can still sacrifice some percentage to propagate Krishna consciousness. This voluntary service to the cause of Krishna consciousness will help one to rise to a higher state of love for God, whereupon one becomes perfect" (1989, p. 642).

As described above, such service must be conducted under the supervision of qualified brähmanas - for even in a material sense, specialised work must be conducted under the direction of an expert to yield the desired result. As Bhaktivedanta Svami alludes in the above, if one cannot directly teach the philosophy and practice of bhakti-yoga, then they can provide some indirect support or donation. This would also be recognised by dualist Vedic accountability. Indeed, a similar form of charity is already acknowledged under Islamic accountability. Like the Vedic position, the Islamic conception of wealth is that God entrusts any assets acquired by man upon him, and man has no absolute ownership of them (Lewis, 2001; Loqman, 1999). Therefore the Muslim is required under Islam to give a type of charity called zakat, which in essence means almsgiving (Khan, 1991). Zakat is an obligatory financial levy on all surplus wealth and agricultural income of Muslims, and is the most important instrument in Islamic societies for redistributing wealth. As Lewis recounts, zakat forms an integral part of Islamic accountability, and its main purpose is to give financial aid to the needy:

"This religious levy is applied to the initial capital of the bank, on the reserves, and on the profits while a major social purpose is to moderate social variances in 
Islamic society, and to enable the poor to lead a normal, spiritual and material life in dignity and contentment" (2001, p. 116).

Zakat, as with the charity given to brāhmanas, is not simply a material practice, but is designed to advance one in spiritual realisation. As Lewis describes:

"The significance of zakat in Islam is different from a welfare programme, and zakat is different from a tax as it is understood today. A tax in a modern society is an obligation of individuals and other entities toward the state, whereas zakat is an obligation of a Muslim not only to society and the state, but also to Allah. In other words zakat is not merely a 'contribution', but also a 'due' or a 'claim'. A person paying zakat is not primarily doing a favour to the recipient or beneficiary of zakat, but is rather meeting a claim on himself by purifying wealth. Of course, the same is true of a Muslim who eschews interest. Neither obligation can be judged in earthly terms alone" (2001, pp. 116-117).

As the purpose of charity in Vedic culture is to support the promotion of bhaktiyoga, like the Islamic zakat, it is described as advancing one spiritually as well, for it is given with the intention of satisfying the higher principal, Krishna.

The unique feature of dualist Vedic accountability is that the higher principal Who is recognised is the summum bonum of existence. Thus, being parts of Krishna themselves, it is in the common interests of the mundane principal and agent to be concerned with the interests of the Supreme. Where this is not firmly realised or properly understood there is potential for conflict of interests, and thus dualist accountability would be contractual. Furthermore, because the higher principal is the summum bonum of existence, dualist Vedic accountability satisfies Shearer's concern for broadening accountability to the other. By taking responsibility for the spiritual wellbeing of the other and informing them of their spiritual needs, one experiences and disseminates a higher taste that fulfils Brown and Cameron's (2000) requirements for reducing overconsumption. Such a higher taste simultaneously challenges present consumerist value orientations and promotes a viable alternative orientation that is pro-social and pro-environmental. This experience of a higher taste is a unique contribution that dualist Vedic philosophy brings to the sustainability literature. 
While other commentators from the Islamic and non-dualist Vedic paradigms have mentioned similar concepts of a higher taste, few have advanced them as a method for changing worldviews and social values. The dualist Vedic philosophy and its theory of accountability has the potential, if combined with enough empirical demonstration, to dig the foundations for an entirely new paradigm of thought. 


\section{Chapter Eight: Dualist and Non-Dualist Accountability}

At the outset of this thesis it was declared dualist and non-dualist theories of sustainable accountability would be compared: how does a dualist theory of accountability, represented by the Gaudìa-Vaisnava school of Vedic philosophy, differ to the non-dualist theory of the Ghandi-Vedic paradigm, as presented by Saravanamuthu (2006)? A summary of these two philosophies and their theories of sustainable accountability is presented in Table 1 at the end of this section. The second section then compares both theories of accountability with respect to Saravanamuthu's (2007) case study of the Riverlands citrus industry.

As described in Chapter Four, Saravanamuthu's (2006) Gandhi-Vedic method of accountability seeks reflexive responses through increased transparency. Gandhi-Vedic accountability was likened to Roberts' socialising forms of accountability, as both through mutual understanding, reach a point of common interest (Roberts, 1991). Saravanamuthu (2007) has likened this satyagrahic accountability to the sustainability efforts of the MESH blockies in the Riverlands citrus community in South Australia. The blockies formulated a vision of communicative action based on techniques such as the collection of the most sustainable horticultural practices, the compilation of a manual of best practices and reviews by internal and external auditors. All these techniques, Saravanamuthu (2007) explains, increase the chance of a rational discourse between the citrus producers and their customers. Thus the blockies envisioned that their customers would view citrus produce as a product rather than a commodity, for a product has a story (of sustainable growing) behind it. Saravanamuthu (2007) suggested that presenting environmental measures in the form of radar plots could supplement such communicative action, for radar plotting can minimise fragmentations of time and space (Saravanamuthu, 2006). These features, especially rational discourse, also characterise Roberts' (1991) socialising forms of accountability. However, satyagrahic accountability is designed to find common interests in situations where one party maintains a stronger position - as Saravanamuthu states, "satyagrahic communicative action refers to the process of argument, reflection and legitimation of claims despite the unequal distribution of power" (2007, p. 7). Therefore, because of low trust relationships with the potential for conflicts of interests, such accountability has 
contractual elements as well: rather than being left to their devices, under Gandhi-Vedic accountability agents would be required to fulfil additional reporting obligations to achieve ahimsic outcomes.

From the dualist Vedic perspective, both satyagrahic accountability and MESH's vision of communicative action illustrate the non-dualist conception of the self - fully competent to reach a conclusion and satisfy oneself through rational discourse. While such accountability significantly extends accountability to the other through increased reflexivity (or spiritual interconnectedness), it does not recognise a higher principal that the mundane principals and agents are responsible to. From the standpoint of dualist Vedic philosophy, the satisfaction of common interests and attainment of ahimsic outcomes require an understanding that the self is not the material body but part of a higher principal - Krishna. Without knowledge of these two factors, actions cannot be classified as in the interests of both (or either) parties, and neither can such actions be regarded as non-violent or responsible for the other, for ultimately one will take common interests to be the gratification of the mind and senses. Thus by accepting Krishna as a higher principal, dualist Vedic accountability has a different understanding of non-violence. As Bhaktivedanta Svami states:

"Ahimsā, nonviolence, means that one should not do anything which will put others into misery or confusion. Material activities that are promised by so many politicians, sociologists, philanthropists etc., do not produce very good results because the politicians and philanthropists have no transcendental vision; they do not know what is actually beneficial for human society. Ahimsa means that people should be trained in such a way that the full utilization of the human body can be achieved. The human body is meant for spiritual realisation, so any movement or any commissions which do not further that end commit violence on the human body. That which furthers the future spiritual happiness of the people in general is called nonviolence" $(1989$, p. 511).

It is this acknowledgement of a higher principal that is the central difference between the two theories of Vedic accountability, and from this difference several other distinctions arise. Alongside a different understanding of nonviolence, dualist Vedic accountability has a different view of how to generate the 
most sustainable behaviours and patterns of consumption. By acknowledging Krishna as the higher principal, dualist accountability provides the opportunity to experience a higher taste, by which one simultaneously becomes detached from lower forms of pleasure and enjoys a completely different worldview and set of values. By not recognising any responsibility to a higher principal, Gandhi-Vedic accountability attempts to reach sustainable outcomes through rational discourse. However, without recognising Krishna as the higher principal, the highest pleasure that Gandhi-Vedic accountability can appeal to is sensory enjoyment. Therefore non-dualist Vedic accountability is not as effective as the dualist at changing social values and worldviews. 


\begin{tabular}{|c|c|c|}
\hline \multirow{2}{*}{$\begin{array}{c}\text { Point for } \\
\text { Comparison }\end{array}$} & \multicolumn{2}{|c|}{ Faction of Vedic Philosophy } \\
\hline & Non-Dualist & Dualist \\
\hline $\begin{array}{l}\text { Conception of the } \\
\text { Self }\end{array}$ & One with God. & Part of God. \\
\hline $\begin{array}{l}\text { Conception of } \\
\text { God }\end{array}$ & $\begin{array}{l}\text { Brahman: the impersonal } \\
\text { sum of all material energy. }\end{array}$ & $\begin{array}{l}\text { Krishna: the summum } \\
\text { bonum, or the personal } \\
\text { source of all energies. }\end{array}$ \\
\hline $\begin{array}{l}\text { Ultimate } \\
\text { Philosophical } \\
\text { Goal }\end{array}$ & $\begin{array}{l}\text { Realisation of the non- } \\
\text { difference of the self with } \\
\text { brahman. }\end{array}$ & $\begin{array}{l}\text { Unmotivated service to } \\
\text { Krishna (love of God). }\end{array}$ \\
\hline $\begin{array}{l}\text { Conception of } \\
\text { Sustainability }\end{array}$ & $\begin{array}{l}\text { Achievement of common } \\
\text { interests and ahimsic (non- } \\
\text { violent) outcomes. }\end{array}$ & $\begin{array}{c}\text { Detachment from material } \\
\text { enjoyment and attachment } \\
\text { to the satisfaction of } \\
\text { Krishna. }\end{array}$ \\
\hline $\begin{array}{l}\text { Method for } \\
\text { Achieving } \\
\text { Sustainable } \\
\text { Outcomes }\end{array}$ & $\begin{array}{l}\text { Satyagraha - the socio- } \\
\text { political discourse whereby } \\
\text { common interests are } \\
\text { reached through rational } \\
\text { dialogue. }\end{array}$ & $\begin{array}{l}\text { A higher taste for Krishna's } \\
\text { pleasure attained via bhakti- } \\
\text { yoga. }\end{array}$ \\
\hline Higher Principal & None recognised. & $\begin{array}{l}\text { Krishna, the summum } \\
\text { bonum of all energies. }\end{array}$ \\
\hline $\begin{array}{l}\text { Techniques for } \\
\text { Sustainable } \\
\text { Accountability }\end{array}$ & $\begin{array}{l}\text { Techniques that establish a } \\
\text { rational dialogue between } \\
\text { parties. Examples are } \\
\text { customised accountability, } \\
\text { the minimised } \\
\text { dichotomisation between } \\
\text { means and ends, increased } \\
\text { reflexivity, forward-looking } \\
\text { accountability and radar } \\
\text { plotting. }\end{array}$ & $\begin{array}{l}\text { Recognition of value for the } \\
\text { direct teaching and practice } \\
\text { of bhakti-yoga, or the } \\
\text { indirect teaching through } \\
\text { the support of qualified } \\
\text { brāhmanas. }\end{array}$ \\
\hline $\begin{array}{l}\text { Nature of } \\
\text { Accountability }\end{array}$ & $\begin{array}{l}\text { Contractual, but with some } \\
\text { similarity between the } \\
\text { characteristics and goals of } \\
\text { social forms of } \\
\text { accountability. }\end{array}$ & $\begin{array}{l}\text { Mostly contractual, though } \\
\text { possibly communal for } \\
\text { those conversant and } \\
\text { experienced in dualist Vedic } \\
\text { philosophy and culture. }\end{array}$ \\
\hline $\begin{array}{l}\text { Method for } \\
\text { Achieving } \\
\text { Greater } \\
\text { Accountability to } \\
\text { the Other }\end{array}$ & $\begin{array}{l}\text { Increased reflexivity, or the } \\
\text { conception of spiritual } \\
\text { interconnectedness. }\end{array}$ & $\begin{array}{l}\text { Responsibility for the } \\
\text { other's spiritual welfare is } \\
\text { required in order to satisfy } \\
\text { Krishna. }\end{array}$ \\
\hline
\end{tabular}

Table 1. Comparison between Dualist and Non-dualist Philosophy and Theories of Sustainable Accountability 


\section{The Riverlands Citrus Industry}

With its theory of social change dependent upon communicative action, Saravanamuthu (2007) states that satyagrahic accountability is better illustrated from an analysis of the agricultural industry, rather than the manufacturing - thus her case study of the Riverlands citrus industry. She states:

\footnotetext{
"The agricultural sector has been deliberately chosen to formulate a vehicle of accountability (through the reiterative process of theory shaping practice, and vice versa) for the following reasons: firstly there is a more direct relationship between the farmer's action/inaction and the socio-environmental consequences than in a manufacturing business. Secondly, agriculture is often sequestering carbon dioxide through the cultivation of crops, or the reduction in land clearing" (Saravanamuthu, 2007, p. 10).
}

However, because of its focus on cultivating sustainable desires, a dualist theory of sustainable accountability can be equally demonstrated from an analysis of the manufacturing industry. Depending upon the specifics of what a manufacturing business produces, it will facilitate the cultivation of either sustainable or consumerist desires within society, and therefore there is a strong relationship between action/inaction and the socio-environmental consequences of such an industry - contrary to what Saravanamuthu (2007) suggests. At the manufacturing level of a citrus industry, for example, produce may not always be regarded as an economic good by dualist Vedic accountability if it is meant only to cultivate consumerist desires, without regard for the health of the body or the non-material identity of the self. Many soft drink manufacturers, for instance, add large quantities of refined sugar to reconstituted citrus juices to give them more appealing taste, yet this is widely understood by nutritionists to be detrimental to the health of the physical and mental bodies of customers. Retailers nonetheless advertise that such products will endow one with pleasure and satisfaction - or social repute - and such manufacturers and retailers are not required to account for the detrimental consequences of consuming such goods, just as Smark (2006) noted that indirect costs of schizophrenia go unaccounted. Holford states: 
"Refining foods makes them last, which makes them more profitable but at the same time deficient in essential nutrients. The food industry has gradually conditioned us to eat sweet foods. Sugar sells, and the more of it we eat the less room there is for less sweet carbohydrates. As our lives speed up we spend less time preparing fresh food and become ever more reliant on ready-meals from companies more concerned with their profit than our health" (1997, p. 27).

Dualism readily acknowledges that the consumption of such beverages is detrimental to the health of the material body, and it encourages businesses being held accountable for such costs. However, more serious than the cost to the material body is that the marketing of such goods socially conditions people to believe that simply by entertaining the senses of the body, they will be satisfied. As the Coke-a-Cola Company states in its annual review, for instance:

"Fanta's vivid advertising reminds consumers to live life in full color. These ads and graphics reinforce Fanta's bubbly, fruity and bold taste experience. By "amazing our senses," we also enliven our desire for play and exuberance" (The Coke-a-Cola Company, 2008).

Therefore, from the dualist perspective, one's accountability needs to be extended to the higher principal Krishna, for unless this is done, the higher levels of wellbeing available through Vedic philosophy are forgone. Instead of recognising a positive value for the manufacture and retail of such goods, a dualist system of accountability would ascribe such actions with a negative value to account for their spiritual and environment costs.

While a manufacturing industry provides an example where goods may not be considered valuable according to a dualist accountability framework, the agricultural industry affords the opportunity to promote Vedic philosophy and culture. Traditionally, Vedic culture was largely rural and agrarian, and contemporary Vedic societies follow suit. The Eco-valley in Hungary is an example (Eco-valley, 2008). It is founded upon the principals of dualist Vedic accountability presented in this thesis, and thus it is managed according to the advice of qualified brāhmanas and directly teaches the philosophy and practical application of bhakti-yoga. Given a goal of the Eco-valley is complete self- 
sufficiency, it has several organic fruit orchards, vegetable gardens and grain fields, and practices the ancient Vedic tradition of cow protection. Other features include independent waste water systems, ox-powered farm equipment and electricity, where required, is generated from solar panels and small windmills. Being accountable to Krishna as a higher principal, the Eco-valley shares its philosophy and experiences with a diverse range of audiences. For this purpose, in 2007 the community established a foundation called the Applied Ecological Sustainability Research Institute (formerly the Sustainability Sciences Research Institute). Through the Eco-Valley Programme (EVP) - the main programme of the foundation - the community collaborates with research institutes, universities, colleges, intellectual workshops, government organisations and leading scientists. The EVP includes scientific conferences, a network of educational centres, educational paths, courses, and versatile communication systems, so that other communities can start developing self-sufficient farms. An ecological and life-style training centre situated in the Eco-valley itself attracts up to fifty thousand visitors annually. Because of their focus on teaching Vedic sustainability practices, there is little doubt in the minds of visitors, consumers or regulators that the Valley's produce is grown in a sustainable, organic way - thus the goal of MESH is achieved by dualist Vedic accountability.

While the Riverlands community is likely to be highly context-specific as to whether it could adopt similar features of dualist accountability, the Hungarian Eco-Valley serves as an example of dualist Vedic accountability in an agricultural environment. Alternatively, instead of directly promoting sustainability through the teaching of Vedic culture, the industry's participants could promote it indirectly, by supporting those who are directly teaching bhaktiyoga. The Coke-a-Cola Company, for instance, present their endeavours to promote sustainable development in their annual review, stating that in 2006 and 2007 they invested nearly one hundred million dollars in community programs such as environmental stewardship, HIV/AIDS prevention and awareness, disaster relief, the promotion of physical activity and education (The Coke-aCola Company, 2008). If it is possible to report donations and endeavours made for material wellbeing, then it is also possible to report contributions that companies give to spreading the philosophy and practice of bhakti-yoga. In these ways, the Riverlands citrus industry could adopt dualist Vedic accountability and 
promote a culture of sustainability by making the higher taste of satisfying the Supreme available to others. 


\title{
Chapter Nine: Operational Feasibility and Research Implications
}

The Vedic literature recognises that to become self-satisfied via the non-dualist method is klesah adhika-tarāh - "very troublesome" (Bhaktivedanta Svami, 1989, verse 12.5). This is because it is difficult to maintain attachment and concentration upon something impersonal. As such, Saravanamuthu (2006) has not recommended the process of self-satisfaction via the non-dualist method but instead put forward Gandhi's advaitic method of satyagraha. As Bhaktivedanta Svami (1989) describes, though, the personal method for attaining a higher taste is not difficult, for it is natural for the living entity. Furthermore, as Krishna explains in the Bhagavad-Gītā, one does not require any material qualification to achieve His satisfaction - even if an offering is not materially impressive, as long as it is made with bhakti, devotion, it is pleasing to Him:

\author{
patram puspam phalam toyam \\ yo me bhaktyā prayacchati \\ tad aham bhkty-upahrtam \\ aśnāmi prayatātmanah
}

"If one offers Me with love and devotion a leaf, a flower, a fruit or water, I will accept it" (Bhaktivedanta Svami, 1989, verse 9.26). Specifically stating that $\mathrm{He}$ will accept insignificant and easily available (vegetarian) items, Krishna declares that His satisfaction does not depend upon material extravagance, although this does not exclude one from making Krishna offerings of utmost extravagance. Not being dependent upon material qualifications, bhakti-yoga forms a sustainable foundation for a theory of accountability, for if Krishna can be satisfied with insignificant resources, so too can His parts that make the offering.

While the application of dualist accountability might be relatively simple at the personal level, its practical application at the organisational or institutional level would first require societal appreciation of the benefits of Vedic culture, and an understanding of how it is non-sectarian - how regardless of one's beliefs, its correct application will yield the promised result. This thesis has been written to stimulate interest in the Vedic paradigm but it acknowledges that, for the majority of the world, to implement such a system of accountability at an 
institutional level, many more real life examples of the benefits and practicality of Vedic culture are required. Therefore this thesis suggests that where Vedic philosophy makes claims its potential for sustainability, these should be subject to further research. As discussed earlier, there is already work documenting the benefits of non-dualist Vedic and Buddhist philosophy (Druhl et al., 2001; Inayatullah, 2005). Similar studies are warranted to investigate the tangible benefits of the dualist philosophy, especially where dualist Vedic accountability has been successfully implemented. This is an initiative shared by economists who support sustainable consumption:

\begin{abstract}
"Economists also can collaborate in research exploring the consumption patterns of communities that already practice or encourage simplified living. Although there are religious and communal groups that strive to practice environmentally responsible lifestyles, their efforts rarely make their way into economic discussions of resource consumption. Studies of such groups would provide important insights into their economic behaviors, social dynamics and quality of life and how they differ from those of a traditional consumer society. As such, these studies may lead to insights regarding potential institutional mechanisms for promoting resource sustainability" (Brown and Cameron, 2000, p. 39).
\end{abstract}

Given current social and environmental problems and the solutions offered in the Vedas, a dualist theory of Vedic accountability presents many research possibilities of critical importance. There are beginnings of such research, with Wolf (1999) suggesting that the tri-guna model presented by Krishna in the fourteenth chapter of the Bhagavad-Gìtà represents a valid framework for understanding human psychology.

It may be suggested, though, that while some parts of dualist Vedic accountability are far from being institutionalised, other aspects are extremely practical. The selective valuation of consumerist goods and services described in the sixth chapter, for example, has been recommended for years by environmental economists, based on the strength of psychological findings. As Lintott states: 
"It may also be argued that, even if desirable, reducing consumption is infeasible or utopian. However this appears so largely because of the assumed relation between consumption and welfare, an assumption that has been strained by two decades in which growth has been accompanied by high unemployment and increasing poverty... However that may be, it is 'sustainable growth' which is unrealistic, along with the idea that it is the most efficient way to promote welfare. The possibilities for reducing consumption while maintaining welfare, and not illusions about saving the environment while increasing consumption, should be the focus of ecological economics" (1998, p. 247).

Following Brown and Cameron, a greater awareness of what does not cause happiness can be one of the first steps toward a higher level of accountability:

"Developing acceptable methods for resource allocation will require extensive work by environmental scientists, economists, and other social scientists. Although it is likely such methods will be developed, they may not be available for many years. Until then, society needs to develop consumption strategies that are likely to promote environmental sustainability in the absence of definitive solutions to these problems. Strategies such as adopting simplified lifestyles that involve general reductions in resource use may prove to be the most viable and effective strategies for the near future" (2000, p. 30).

Furthermore, while a nationwide adoption of dualist Vedic accountability may yet be far off, social studies infer that some organisations, already having an environmentally friendly orientation, would be willing to adopt a dualist Vedic framework. Research on social values and cultural ethics (Inglehart, 1990; Schwartz, 1992; Stern et al., 1995) indicate that a consumerist value orientation is not the only ethic held by members of Western societies. These studies have indicated that a growing trend toward post-materialist, altruistic, and ecological values in Western countries may reflect an alternative value system that promotes simplified lifestyles and lower consumption. Social scientists have observed two distinctive classes of values systems amongst members of Western societies. The first class has been branded as materialistic (Inglehart, 1990), selfenhancing (Schwartz, 1992) or egocentric (Stern et al., 1995) as it places importance on wealth, social power, authority, and control - values which 
closely correspond with a consumerist orientation. The second class of values, have been labelled post-materialistic (Inglehart, 1990), self-transcending (Schwartz, 1992), social-altruistic, or biospheric (Stern et al., 1995). This value system is instead orientated towards nonmaterial goals such as social justice, preservation of the environment, a world of beauty, self-esteem, cooperation and altruism (Brown and Cameron, 2000). It is suggested here that organisations adhering to the second class of values may be more inclined - if correctly informed - to adopt certain principals of dualist Vedic accountability. For those organisations, the Vedic worldview and ethical values are not so far distant from their own, and therefore such organisations may be inclined to experiment with the dualist theory of accountability. 


\section{Chapter Ten: Concluding Comments}

This thesis has described significant features of a dualist Vedic theory of sustainable accountability and compared them with a non-dualist theory. However, the term sustainable does not adequately describe a fully-fledged system of dualist accountability. The expression sustainability implies that humans can adjust their patterns of production and consumption, so that natural resources can be replaced at least at the rate they are being used, rather than being continuously diminished (Costanza, Daly and Bartholomew, 1991). This concept, though, fails to capture the potential for environmental conservation offered by a dualist system of accountability. The phrase accountability of abundance, or its like, would more adequately describe the dualist theory for, instead of simply replacing natural resources, under a well implemented system of dualist accountability, the entire ecological system thrives. This is related on several different occasions in the Vedic texts, and one such instance is reproduced in this final chapter.

Rather than ascribing to the linear Judeo-Christian notion of time, the Vedas give a cyclic explanation of time. Indeed, the Judeo-Christian model of time embraced by most of the developed world also measures time in many cyclic ways - seconds, minutes, hours, days, weeks, months and seasons all pass through repetitive cycles. Rather than departing from the cyclic conception of time in periods of years, the Vedas describe a cycle of four reoccurring millenniums, which are comparable to the four seasons. The linear conception of time held by modern science runs parallel to the notion of human progress - that over time, humans advance their technology, standard of living, and understanding of the universe. Conventional Western doctrine asserts that modern humans evolved from other humanoid species approximately two hundred thousand years ago, and, since then anatomically modern humans have advanced many fields to reach the current standard of civilisation. The Vedas, however, instead of suggesting the evolution of the human race, present its devolution (Cremo, 2003). The Vedas describe that, millenniums ago, human beings were highly advanced in spiritual understanding and culture, and 
consequently they were very satisfied and extremely powerful. ${ }^{24}$ As time passed, though, their finer qualities began to decline. When considering the current social and environmental degradation in the world, the Vedic suggestion of human devolution is a more compatible explanation of human history than notions of human progress.

The Vedas divide time according to descending periods of human quality. Four broad categories called yugas, or ages divide these periods. These may be compared to the four seasons but they are more commonly compared to different metals, just as modern historians allocate different populaces to different ages, such as the Bronze Age and the Iron Age. According to the Vedas, the 'spring' age is called Satya-yuga, or the Golden Age. In Satya-yuga, which was many millennia ago, people were for the most part, self-satisfied, peaceful and tolerant. The following 'summer' age was called Tretā-yuga, the Silver Age, and in this yuga, most of the populace were brāhmanas - spiritual intellectuals. Although most people were religious, occasionally their performance was marred by ulterior motives, especially the desire for prestige. Nonetheless, people were free from excesses of lust and anger. In the next 'autumn' age, Dvāpara-yuga (the Bronze Age), people would commonly pursue glory and nobility. The population consisted of large numbers of the Vedic martial and administrative class. People would devote themselves to Vedic study as well as to accumulating extraordinary wealth, fame and power. Qualities like greed, self-interest and dissatisfaction were gradually becoming more prevalent. Finally, the present age known as Kaliyuga - the Iron Age or the 'winter' age - is characterised by a human population that is generally self-interested in behaviour, materialistic, and dissatisfied. Five thousand years ago it was foretold that the qualities of the people in Kali-yuga would be influenced by the values of the capitalist social structure:

\section{vittam eva kalau nrnām}

janmācāra-gunadayah

\footnotetext{
${ }^{24}$ Consequently, the Vedas do not ascribe to Darwin's theory of evolution, but hold that intelligent humans have existed on Earth for millions of years. This is not contrary to archaeological findings, for, outside of mainstream research, there are many documented cases where the remains anatomically modern humans have been found deeply embedded in layers of rock dated to be many millions of years old (Cremo and Thompson, 1998). A review of this literature is not within the scope of this thesis, though interested readers may refer to Cremo and Thompson $(1994,1998)$.
} 


\section{dharma-nyāya-vyavasthāyām}

\section{kāranam balam eva hi}

"In Kali-yuga, wealth alone will be considered the sign of a man's good birth, proper behavior and fine qualities. Law and justice will be applied on the basis of one's power" (Disciples of Bhaktivedanta Svami, 1988, verse 12.2.2). Given the self-interested nature of the human populace in Kali-yuga, it is of little surprise that the world faces dire environmental and social problems. The Vedas, however, do not support the theory that since Kali-yuga is in effect, revolutionaries are powerless to effect change. Instead the Vedas encourage decisive action. The Śrimad-Bhāgavatam, for instance, describes that through accountability to God, it is possible to attain a situation equivalent to that in the Golden Age, Staya-yuga. This was so during the reign of Lord Rāmacandra (an incarnation of Krishna), during the period of Tretā-Yuga:

tretāyām vartamānāyām
kālah krta-samo 'bhavat
rāme rājani dharma-jũe
sarva-bhūta-sukhāvahe

"Lord Rāmacandra became King during Tretā-yuga, but because of His good government, the age was like Satya-yuga. Everyone acted according to Vedic injunction and was completely happy" (Bhaktivedanta Svami, 1988, verse 9.10.51). During the reign of Lord Rāmacandra, the populace was expertly held accountable via principles similar to those mentioned in this thesis. Because everyone was held accountable to God, everyone achieved a higher taste, and, consequently, a situation was created just like the Golden Age, where people were not interested in lesser, materialistic pleasures. And as the Bhägavatam states, this was more than a sustainable situation:

\footnotetext{
vanāni nadyo girayo

varsāni dvīpa-sindhavah

sarve kāma-dughā āsan

prajānām bharatarsabha
} 
nādhi-vyādhi-jarā-glāni-

duhkha-śoka-bhaya-klamāh

mrtyuś cānicchatām nāsìd

rāme rājany adhoksaje

"O Mahārāja Parīksit, best of the Bharata dynasty, during the reign of Lord Rāmacandra the forests, the rivers, the hills and mountains, the states, the seven islands and the seven seas were all favorable in supplying the necessities of life for all living beings. When Lord Rāmacandra, the Supreme Personality of Godhead, was the King of this world, all bodily and mental suffering, disease, old age, bereavement, lamentation, distress, fear and fatigue were completely absent. There was even no death for those who did not want it" (Bhaktivedanta Svami, 1988, verses 9.10.52-53). Therefore the theory of accountability presented in this thesis is not simply a theory for sustainability, but is a theory for plenty. As Bhaktivedanta Svami states, "A similar situation [to the reign of Lord Rāmacandra] could be introduced immediately, even in this age called Kali, the worst of all ages" (1988, Ninth Canto, p. 361).

While the Vedic theory of sustainability might seem incredible, this thesis has argued that the Vedas should be accepted in academic discourse, not on grounds of religious belief, but on the strength of spiritual experience. One can, for instance, adopt the principles of Vedic accountability and experience a situation similar to Satya-yuga, the Golden Age, and in such an experimental way, study the Vedas. Archer et al. (2004) have similarly argued that the question of God's existence should be allowed entrance into the academic arena on the grounds of spiritual experience, for all debates, they contend, arise from differing standpoints of experience. In order for spiritual experiences to be accepted as evidence of a transcendental reality, though, Archer et al. explain that a model must exist in academia that accepts that man can be influenced by the direct experience of reality. To this end, the critical realist model was suggested as making such an acknowledgement.

The Vedas assert that there is a process that one may follow to obtain the experience of a transcendental reality, and this thesis began to describe it in stating that if one satisfies Krishna, they too will become completely satisfied - 
even if having done nothing to satisfy their own mind and senses. To deny the Vedas entrance to the academic arena when there is a means of verifying what they describe imposes a standard upon spiritual topics not applied to their material counterparts - similar to when Aristotelian metaphysicists refused to look through Galileo's telescope because they did not want to see their paradigm completely refuted in a glance. It is the aspiration, then, of the dualist Vedic philosopher, to see that what is currently viewed as a religion will come to be known as a science.

Because of the contribution it can make to ecological economics and accounting, this thesis has asserted that a Vaisnava theory of accountability and sustainability should be heard in academia, in addition to non-dualist theories. Thousands of years ago, it was predicted that the Vedas would be "contaminated by the speculative interpretations of atheists" (vedāh pāsanda-dūsitāh) (Disciples of Bhaktivedanta Svami, 1988, verse 12.3.32). Now, considering the non-dualist theories that propose that man is God, it is possible to see the fruition of this prediction:

\footnotetext{
"The universal religion that Vivekananda taught was a modernized form of Vedanta and Hinduism with its broad approach to Truth. According to "Practical Vedanta" none of us are limited or weak. None of us are fallen and in need of redemption. We are not sick, or in need of comfort or healing. We are not a little body or limited mind. We are not even souls or children of God; we are God. No, we are greater than God. We are, each one of us, the self of all beings. This entire universe of matter and mind is no more than our shadow. It is beneath our dignity as the master of the universe to be dominated by anger, fear or desire, to want anything or to be the slaves of anyone's opinion" (Gupta, 2007, p. 644).
}

However, it may be argued that if the living entity is "greater than God" (Gupta, 2007, p. 644), then he should not be struggling for existence in the material world, trying for enjoyment in a body doomed to fail. The non-dualist will reply that the living entity is only temporarily covered by illusion, and that through yoga, meditation and service to man he can come to the enlightened understanding that he is God (Gupta, 2007). However, the dualist may then 
respond with the statement that if God can be covered by illusion, then it is illusion, rather than the living entity, that is greater than God.

While the Vedas should be accepted in academic circles, it should be understood that to give an authentic representation of the Vedas, one must possess certain qualifications. This same principle also applies in material life to be recognised as an authority in any field, one must have an accredited qualification. Krishna declared to Arjuna that he would understand the Bhagavad-Gìtā without misinterpretation because he was bhakto 'si me sakhāKrishna's friend and devotee. Therefore, Krishna is explaining that He reserves the right not to reveal Himself in person to the challenging living entity who thinks that God should appear on his demand, and who lacks the qualification of bhaki, devotion to God. Even in the material sense one does not reveal personal aspects of himself to a stranger, but to a trusted friend, a sakhā. Therefore, to lack these qualifications and yet claim that God is impersonal, that God does not exist, or that man is God (or greater than God), is to impose on spiritual topics a double standard, a standard that one would not tolerate imposed upon themselves in a material context. This requirement for understanding the Vedas is often overlooked, yet it is the first and one of the most important principles in understanding the Vedas and in understanding God. Because this thesis is written from the Gaudiya-Vaisnava perspective, it offers an authentic presentation of Vedic accountability. 


\section{References}

Abdel Haleem, H. (1998), "Introduction”, In Abdel Haleem H. (Ed.), Islam and the Environment, London: Ta-Ha.

Ahuvia, A. C. \& Wong, N. (1995), "Materialism: Origins and implications for personal well-being", In Hansan, F. (Ed.), European Advances in Consumer Research, Copenhagen: Association for Consumer Research.

Anjum, M. I. (1996), "Eternal challenge of Islamic economics to capitalism and communism”, Humanomics, 12, 1, 53-90.

Archer, M. S. (2004), "Models of man: The admission of transcendence", In Archer, M. S., Collier, A. \& Porpora, D. V. (Eds.), Transcendence: Critical Realism and God, London: Routledge.

Archer, M. S., Collier, A. \& Porpora, D.V. (2004), Transcendence: Critical Realism and God, London: Routledge.

Aronson, E. (1990), “Applying social psychology to desegregation and energy conservation”, Personality and Social Psychology Bulletin, 16, 118-132.

Arrington, C. E. \& Francis, J. (1993), “Giving economic accounts: Accounting as a cultural practice", Accounting, Organisations and Society, 18, 2/3, 107124.

Basham, A. L. (1954), The Wonder that was India, New York: Grove Press

Beck, U. (1993), Risk Society: Towards a New Modernity, Trans. Ritter, M., London: Sage Publications.

Beed, C. \& Beed, C. (2004), "Distributional implications of contemporary JudeoChristian economics", International Journal of Social Economics, 31, 10, 903-922. 
Belk, R. W. (1984), “Three scales to measure constructs related to materialism: Reliability, validity, and relationships to measures of happiness", Advances in Consumer Research, 11, 291-297.

Belk, R. W. (1985), "Materialism: Trait aspects of living in the material world", Journal of Consumer Research, 12, 265-280.

Benston, G. J. (1982), “Accounting and corporate accountability”, Accounting, Organizations and Society, 7, 2, 87-105.

Bhaktivedanta Svami, A. C. (1970), The Nectar of Devotion: The Complete Science of Bhakti-Yoga, Mumbi: The Bhaktivedanta Book Trust International Inc.

Bhaktivedanta Svami, A. C. (1987), Śrimmad-Bhāgavatam, Australia: The Bhaktivedanta Book Trust.

Bhaktivedanta Svami, A. C. (1988), Śrīmad-Bhāgavatam, Australia: The Bhaktivedanta Book Trust.

Bhaktivedanta Swami, A. C. (1989), Bhagavad-Gìtā As It Is, Australia: The Bhaktivedanta Book Trust.

Bhaktivedanta Svami, A. C. (1996), Śrī Caitanya-Caritāmrta (Antya-Līlā), Australia: The Bhaktivedanta Book Trust.

Bhaktivedanta Svami, A. C. (1996), Śrī Caitanya-Caritāmrta (Madhya-Līlāa), Australia: The Bhaktivedanta Book Trust.

Bhaskar, R. A. (1975), A Realist Theory of Science, London: Verso.

Bhaskar, R. A. (1979), The Possibility of Naturalism, London: Routledge. 
Bhaskar, R. A. (1993), Dialectic: The Pulse of Freedom, London: Verso.

Bhaskar, R. A. (1998), "General introduction”, in Archer, M., Bhaskar, R., Collier, A., Lawson, T. \& Norrie A. (Eds), Critical Realism: Essential Readings, Oxon: Routledge.

Bhaskar, R. A. (2000), From East to West: The Odyssey of the Soul, London: Routledge.

Bhattacharyya, A. K. (1988), Modern Accounting Concepts in Kautilya's Arthaśāstra, Calcutta: Firma KLM Private.

Bishop, D. H. (1985), Chinese Thought: An Introduction, New Delhi: Motilal Banarsidass.

Biswas, N. B. (1998), "Economics and ethics in an Indian society: A reflective analysis", International Journal of Social Economics, 25, 6/7/8, 10641072.

Booth, P. (1993), "Accounting in Churches: A research framework and agenda", Accounting, Auditing and Accountability Journal, 6, 2, 37-67.

Brown, P. M. \& Cameron, L. D. (2000), "What can be done to reduce overconsumption?", Ecological Economics, 32, 27-41.

Cameron, L. D., Brown, P. M. \& Chapman, J. G. (1998), "Social value orientations and decisions to take pro-environmental action", Journal of Applied Social Psychology, 28, 675-697.

Carver, C. S. \& Baird, E. (1998), “The American dream revisited: Is it what you want or why you want it that matters?" Psychological Science, 9, 289292. 
Chakraborty, S. K. \& Chakraborty, D. (2007), "The economic function in the Hindu worldview: Its perennial social relevance", International Journal of Social Economics, 34, 10, 714-734.

Chapra, U. M. (1992), Islam and the Economic Challenge, Leicester: The Islamic Foundation.

Chowdhury, M. A. M. (1999), "Resource allocation, investment decisions and economic welfare: Capitalism, socialism and Islam", Managerial Finance, 25, 5, 35-51.

Chwastiak, M. \& Young, J. J. (2003), "Silences in annual reports", Critical Perspectives in Accounting, 14, 533-552.

Cohen, P. \& Cohen, J. (1996), Life Values and Adolescent Mental Health, Mahwah: Erlbaum.

Collier, A. (2004), "The masters of suspicion and secularisation”, In Archer, M. S., Collier, A. \& Porpora, D. V. (Eds.), Transcendence: Critical Realism and God, London: Routledge.

Commoner, B. (1990), Making Peace with the Planet, New York: Pantheon.

Cooper, C. (1992), "The non and nom of accounting for (m)other nature", Accounting, Auditing and Accountability Journal, 5, 3, 16-39.

Costanza, R., Daly, H. E. \& Bartholomew, J. A. (1991), “Goals, agenda, and policy recommendations for ecological economics", In Costanza, R. (Ed.), Ecological Economics: The Science and Management of Sustainability, New York: Columbia University.

Cremo, M. A. (2003), Human Devolution: A Vedic Alternative to Darwin's Theory, Los Angeles: The Bhaktivedanta Book Trust. 
Cremo, M. A. \& Thompson, R. L. (1994), Hidden History of the Human Race, California: Govardhan Hill Publishing.

Cremo, M. A. \& Thompson, R. L. (1998), Forbidden Archaeology: The Full Unabridged Edition, (2 ${ }^{\text {nd }}$ Edition), San Diego: Torchlight Publishing.

Dalton, D. (1993), Mahatma Gandhi: Nonviolent Power in Action, New York: Columbia University Press.

Daly, H. E. (1992), Steady-State Economics, London: Earthscan.

Daniels, P. L. (1998), "Economic change, the environment and Buddhism in Asia”, International Journal of Social Economics, 25, 6/7/8, 968-1004.

Dawson, S. (1988), “Trait materialism: Improved measures and an extension to multiple domains of life satisfaction", In Shapiro S. \& Walle A. H. (Eds.), AMA Winter Educators Conference Proceedings, Chicago: American Marketing Association.

Dawson, S. \& Bamossy, G. (1991), "If we are what we have, what are we when we don't have?" Journal of Social Behaviour and Personality, 6, 363384.

Derrida, J. (1993), "Sauf le nom”, translated by Leavey J., In Dutoit, T. (Ed.), On the Name, Stanford: Stanford University Press.

Devall, B. (1988), Simple in Means, Rich in Ends: Practicing Deep Ecology, Salt Lake City: Peregrine Smith Books.

Devamrita Svami, H. H. (1996), Perfect Escape, Australia: The Bhaktivedanta Book Trust.

Devamrita Svami, H. H. (2002), Searching for Vedic India, Australia: The Bhaktivedanta Book Trust. 
DeYoung, R. (1989), “Changing behavior and making it stick", Environmental Behavior, 25, 485-505.

Diener, E. \& Oishi, S. (2000), "Money and happiness: Income and subjective well-being across nations", In Diener E. \& Suh E. M. (Eds.), Subjective Well-being Across Cultures, Cambridge: MIT Press.

Diener, E., Sandvik, E., Seidlitz, L. \& Diener, M. (1993), "The relationship between income and subjective wellbeing: Relative or absolute?" Social Indicators Research, 28, 195-223.

Dillbeck, M. C., Landrith III, G. \& Orme-Johnson, D. W. (1981), "The Transcendental Meditation program and crime rate change in a sample of forty-eight cities", Journal of Crime and Justice, 4, 25-45.

Disciples of Bhaktivedanta Svami, A. C. (1988), Śrīmad-Bhāgavatam, Australia: The Bhaktivedanta Book Trust.

Drekmeier, C. (1962), Kingship and Community in Early India, Stanford: Stanford University Press.

Druhl, K., Langstaff, J. \& Monson, N. (2001), "Towards a synthesis of the classical and quantum paradigms: Vedic Science as a holistic approach to organizational change", Journal of Organizational Change Management, $14,4,379-407$.

Durkheim, E. (1976), The Elementary forms of the Religious Life, (2nd edition), Translated by Sawin, J. W., London: George Allen and Unwin.

Durning, A. (1992), How Much is Enough?, New York: W.W. Norton and Co.

Easterbrook, G. (2003), The Progress Paradox, New York: Random House. 
Easterlin, R. (1995), "Will raising the incomes of all increase the happiness of all?" Journal of Economic Behaviour and Organization, 27, 25-37.

Easterlin, R. (2001), "Income and happiness: Towards a unified theory", Economic Journal, 111, 456-484.

Eco-valley (2008), Eco-valley, Retrieved from: http://ecovalley.hu/, accessed at 16 Dec., 2008.

Faircloth, A. (1988), "The importance of accounting to the Shakers." Accounting Historians Journal, 15, 2, 99-129.

Foucault, M. (1979), Discipline and Punish, Harmondsworth: Penguin.

Francfort, P. H. (1992), "Evidence for Harappan Irrigation System in Haryana and Rajasthan", Eastern Anthropology, 45, 87-103.

Frank, R. H. (1999), Luxury Fever, New York: The Free Press.

Frey B. S. \& Stutzer A. (2002), Happiness and Economics: How the Economy and Institutions Affect Well-being, Princeton: Princeton University Press.

Gallhofer, S. \& Haslam, J. (1996), “Accounting/art and the emancipatory project: Some reflections", Accounting, Auditing and Accountability Journal, 9, 5, 23-44.

Gallhofer, S. \& Haslam, J. (1997), "Beyond accounting: the possibilities of accounting and 'critical' accounting Research", Critical Perspectives on Accounting, 8, 1/2, 71-95.

Gandhi, M. K. (1961), The Collected Works of Mahatma Gandhi (35), India: Publications Division, Ministry of Information and Broadcasting, Government of India. 
Gandhi, M. K. (2001), India of my Dreams, Compiled by Prabhu, R. K., Ahmedadbad: Navajivan Publishing House.

Ghosh, B. N. (2007), "Understanding Gandhian dialectics", Humanomics, 23, 4, 197-203.

Goodland, R. (1992), "The case that the world has reached its limits", In Goodland, R., Daly, H. E. \& Serafy, S. E. (Eds.), Population, Technology and Lifestyle, Washington: Island Press.

Gray, R. (1992), "Accounting and environmentalism: An exploration of the challenge of gently accounting for accountability, transparency, and sustainability”, Accounting, Organizations, and Society, 17, 5, 399-425.

Gray, R. (2006), "Social, environmental and sustainability reporting and organisational value creation? Whose value? Whose creation?" Accounting, Auditing \& Accountability Journal, 19, 6, 793-819.

Groff, R. (2004), Critical Realism, Post-Positivism and the Possibility of Knowledge, London: Routledge.

Gupta, A. D. (2007), "Social responsibility in India: Towards a global compact approach", International Journal of Social Economics, 34, 9, 637-663.

Hahn, F. \& Hollis, M. (1979), Philosophy and Economic Theory, Oxford: Oxford University Press.

Harahap, S. S. (2006), "Social accounting in Islamic political economy", Humanomics, 22, 1, 34-46.

Heaton, D. P. \& Harung, H. S. (1999), "The conscious organisation", The Learning Organisation, 6, 4, 157-162. 
Hellmon, M. E. (1994), "Resist not evil", In Gandhi, A. (Ed.), World Without Violence, New York: M. K. Gandhi Institute.

Henderson, H. (1991), "New markets, new commons, new ethics: A guest essay", Accounting, Auditing and Accountability Journal, 4, 3, 72-80.

Hines, J. M., Hungerford, H. R. \& Tomers, A. N. (1987), “Analysis and synthesis of research on responsible environmental behavior: A meta-analysis", Journal of Environmental Education, 18, 1-8.

Hines, R. D. (1988), "Financial accounting: In communicating reality, we construct reality", Accounting, Organizations and Society, 13, 3, 251-261.

Hines, R. D. (1989), "The socio-political paradigm in financial accounting research", Accounting, Auditing \& Accountability Journal, 2, 1, 52-76.

Hines, R. D. (1992), “Accounting: Filling the negative space”, Accounting, Organizations and Society, 17, 3-4, 313-341.

Ho, D. Y. F. (1995), "Selfhood and identity in Confusianism, Taoism, Buddhism and Hinduism: Contrast with the West", Journal for the Theory of Social Behaviour, 25, 115-140.

Hofstede, G. (1980), Culture’s Consequences, New York: Sage.

Holford, P. (1997), The Optimum Nutrition Bible, London: Judy Piatkus Publishers.

Huyghe, R. \& Ikeda, D. (1991), Dawn After Dark, New York: Weatherhill.

Ibrahim, S. H. M. (2000), "Nurtured by 'Kufr': The Western philosophical assumptions underlying conventional (Anglo-American) accounting", International Journal of Islamic Financial Services, 2, 2, 19-38. 
Inayatullah, S. (2005), “Spirituality as the forth bottom line?”, Futures, 37, 573579.

Inglehart, R. (1990), Culture Shift in Advanced Industrial Society, Princeton: Princeton University Press.

Irvine, H. (2005), "Balancing money and mission in a local church budget", Accounting, Auditing \& Accountability Journal, 18, 2, 211-237.

Iyer, G. R. (1999), “The impact of religion and reputation in the organization of Indian merchant communities", Journal of Business and Industrial Marketing, 14, 2, 102-117.

Jacobs, K. (2005), "The sacred and the secular: Examining the role of accounting in the religious context", Accounting, Auditing and Accountability Journal, 18, 2, 189-210.

Jacobs, K \& Walker, S. P. (2004), “Accounting and accountability in the Iona Community", Accounting, Auditing and Accountability Journal, 17, 3, 361-381.

Jayatilleke, K. N. (2000), Dhamma, Man and Law, Dehiwela: Buddhist Cultural Centre.

Kamla, R., Gallhofer, S. \& Haslam, J. (2006), "Islam, nature and accounting: Islamic principles and the notion of accounting for the environment", Accounting Forum, 30, 245-265.

Kanagasabapathi, P. (2007), "Ethics and values in Indian economy and business", International Journal of Social Economics, 34, 9, 577-585.

Kasser, T. (2002), The High Price of Materialism, Massachusetts: The MIT Press. 
Kasser, T. \& Ryan R. M. (1993), “A dark side of the American dream: Correlates of financial success as a central life aspiration", Journal of Personality and Social Psychology, 65, 410-422.

Kasser, T. \& Ryan R. M. (1996), "Further examining the American dream: Differential correlates of intrinsic and extrinsic goals", Personality and Social Psychology Bulletin, 22, 280-287.

Khan, M. A. (1991), "The Future of Islamic Economics”, Futures, 2, 248-261.

Kreander, N., McPhail, K. \& Molyneaux, D. (2004), “God's fund managers: A critical study of stock market investment practices of the Church of England and UK Methodists", Accounting, Auditing and Accountability Journal, 17, 3, 408-441.

Kronenberg, J. (2007), "Making consumption "reasonable"”, Journal of Cleaner Production, 15, 557-566.

Lane, R. E. (2000), The Loss of Happiness in Market Democracies, New Haven: Yale University Press.

Laughlin, R. (1988), "Accounting in its social context: An analysis of the accounting systems in the church of England", Accounting, Auditing and Accountability, 1, 2, 19-42.

Laughlin, R. (1990), "A model of financial accountability and the Church of England", Financial Accountability \& Management, 6, 2, 95-114.

Laughlin, R. (1996), "Principals and higher principals: Accounting for the accountability in the caring professions”, In Munro, R. \& Mouritsen, J. (Eds.), Accountability: Power, Ethos and the Technologies of Managing, London: Copenhagen Business School. 
Layard, R. (2005), Happiness Lessons from a New Science, London: Penguin Press.

Lehman, G. (1995), “A Legitimate concern for environmental accounting”, Critical Perspectives on Accounting, 6, 5, 393-412.

Lehman, G. (1999), "Disclosing new worlds: A role for social and environmental accounting and auditing”, Accounting, Organizations, and Society, 24, 3, 217-242.

Leventhal, H. \& Cameron, L. D. (1994), "Persuasion and health attitudes", In Shavitt, S. \& Brock, T. C. (Eds.), Persuasion: Psychological Insights and Perspectives, Boston: Allyn and Bacon.

Lewis, M. K. (2001), "Islam and accounting”, Accounting Forum, 25, 2, 103 125.

Lightbody, M. (2000), "Storing and shielding: Financial management behaviour in a church organisation", Accounting, Auditing and Accountability Journal, 1, 2, 156-174.

Lintott, J. (1996), “Environmental Accounting: Useful to whom and for what?", Ecological Economics, 16, 179-190.

Lintott, J. (1998), "Beyond the economics of more: The place of consumption in ecological economics", Ecological Economics, 25, 239-248.

Liyanarachchi, G. A. (2007), "Conception of accountability in Buddhism: An exploratory essay", Paper presented at the Fifth Asia Pacific Interdisciplinary Research in Accounting Conference, Auckland.

Loqman, M. (1999), “A brief note on the Islamic financial system”, Managerial Finance, 25, 5, 52-59. 
Lovell, A. (1995), "Moral reasoning and moral atmosphere in the domain of accounting", Accounting, Auditing \& Accountability Journal, 8, 3, 60-80.

Lovelock, J. E. (1995), The Revenge of Gaia. Why the Earth is Fighting BackAnd how we can still save Humanity, London: Penguin Books.

Maali, B., Casson, P. \& Napier, C. (2003), "Social reporting by Islamic banks", Discussion Papers in Accounting and Finance, University of Southampton, September, Number AF03-13. ISSN 1356-3548.

Mahadevan, T. M. P. (1954), Outlines of Hinduism, Bombay: Chetana Pvt.

Maslow, A. H. (1954), Motivation and Personality, New York: Norton.

Mattessich, R. (1998), "Review and extension of Bhattacharyya's modern accounting concepts in Kautilya's Arthaśāstra", Accounting, Business and Financial History, 8, 2, 191-209.

McHoskey, J. W. (1999), "Machiavellianism, intrinsic values versus extrinsic goals, and social interest: A self-determination theory analysis", Motivation and Emotion, 23, 276-283.

McKernan, J. F. \& Kosmala, K. (2007), "Doing the truth: Religion deconstruction - justice, and accounting”, Accounting, Auditing \& Accountability Journal, 20, 5, 729-764.

McPhail, K., Gorringe, T. \& Gray, R. (2004), “Accounting and theology, an introduction", Accounting, Auditing and Accountability Journal, 17, 3, 320-326.

McPhail, K., Gorringe, T. \& Gray, R. (2005), "Crossing the great divide: Critiquing the sacred secular dichotomy in accounting research", Accounting, Auditing and Accountability Journal, 18, 2, 185-188. 
Movement for Ecologically Sustainable Horticulture Inc. (MESH) (2003), Manual and Audit Tables, Version 1, Privately Printed by MESH.

Mick, D. G. (1996), “Are studies of dark side variables confounded by socially desirable responding? The case of materialism", Journal of Consumer Research, 23, 106-119.

Millbank, J. (1990), Theology and Social Theory: Beyond Secular Reason, Oxford: Basil Blackwood.

Myers, D. G. \& Diener, E. (1996), “The pursuit of happiness", Scientific American, May, 70-72.

Nathan, S. \& Ribiere, V. (2007), "From knowledge to wisdom: The case of corporate governance in Islamic banking”, The Journal of Information and Knowledge Management Systems, 34, 4, 471-483.

Noreen, E. (1988), “The economics of ethics: A new perspective on agency theory", Accounting, Organizations and Society, 10, 1, 87-102.

Omar Naseef, A. (1998), "The Muslim declaration on nature", In H. Abdel Haleem (Ed.), Islam and the Environment, London: Ta-Ha.

Oslington, P. (2000), “A theological economics”, International Journal of Social Economics, 27, 1, 32-44.

O'Sullivan, E. (1999), Transformative Learning: Educational Vision for the 21st Century, Toronto: University of Toronto Press.

Pareka, B. (1991), Gandhi's Political Philosophy: A Critical Examination, Houndsmills: Macmillan.

Peace, R. (2006), "Accountants and a religious covenant with the public", Critical Perspectives in Accounting, 17, 781-797. 
Philip, P. (1995), “Transcendental realism”, International Journal of Social Economics, 22, 12, 19-35.

Pomeranz, F. (1997), “The accounting and auditing organization for Islamic financial institutions: An important regulatory debut", Journal of International Accounting, Auditing \& Taxation, 6, 1, 123-130.

Porpora, D. (2000), "The Sociology of Ultimate Concern”, Alethia, 3, 1, 10-15.

Potter, G. \& Lopez, J. (2001), “After postmodernism: The millennium”, In Lopez, J. \& Potter, G. (Eds.), After Postmodernism: An Introduction to Critical Realism, London: The Athlone Press.

Rahman, Y. A. (1994), Interest Free Islamic Banking, Kuala Lumpur: Al-Hilal Publishing.

Rangarajan, L. N. (1992), Kautilya: The Arthaśāstra. Edited, rearranged, translated and introduced by Rangarajan L. N., New Delhi: Penguin Books.

Richins, M. L. \& Dawson, S. (1992), “A consumer values orientation for materialism and its measurement: Scale development and validation", Journal of Consumer Research, 19, 303-316.

Roberts, J. (1991), "The possibilities of accountability", Accounting, Organizations and Society", 16, 4, 355-368.

Roberts, J. \& Scapens, R. (1985), “Accounting systems and systems of accountability - Understanding accounting practices in their organisational contexts", Accounting, Organizations and Society”, 10, 4, 443-456. 
Roberts, M. L. \& Robbins, R. W. (2000), "Broad dispositions, broad aspirations: The intersection of personality traits and major life goals", Personality and Social Psychology Bulletin, 26, 1284-1296.

Rolland, R. (1988), The Life of Vivekananda and the Universal Gospel, Trans. Malcom-Smith, E. F., Calcutta: Advaita Ashrama.

Rorty, R. (2005), “Anticlericalism and atheism”, In Zabala, S. (Ed.), The Future of Religion, New York: Columbia University Press.

Rosen, S. J. (2006), Essential Hinduism, London: Praeger.

Rutherford, M. B., Knetsch, J. L. \& Brown, T. C. (1998), “Assessing environmental losses: Judgements of importance and damage schedules", Harvard Environmental Law Review, 22, 1, 51-70.

Ryan, R. M. \& Deci, E. L. (2000), "Self-determination theory and the facilitation of intrinsic motivation, social development, and well-being", American Psychologist, 55, 68-78.

Sagoff, M. (1988), The Economy of the Earth, Cambridge: Cambridge University Press.

Saravanamuthu, K. (2006), "Gandhian-Vedic paradigm: Theorising sustainable development”, In Hoque, Z. (Ed.), Methodological Issues in Accounting Research: Theories, Methods and Issues, London: Spiramus.

Saravanamuthu, K. (2007), "A journey of socialising the risks associated with global warming: A Gandhian insight into Schumacher's total accounting and accountability", Paper presented at the Fifth Asia Pacific Interdisciplinary Research in Accounting Conference, Auckland. 
Schroeder, J. E. \& Dugal, S. S. (1995), "Psychological correlates of the materialism construct", Journal of Social Behaviour and Personality, 10, 243-253.

Schwartz, B. (2004), The Paradox of Choice: Why More is Less, New York: HarperCollins.

Schwartz, S. H. (1992), "Universals in the content and structure of values: Theoretical advances and empirical tests in 20 countries", Advances in Experimental Social Psychology, 25, 1-65.

Schweiker, W. (1993), “Accounting for ourselves: Accounting practice and the discourse of ethics", Accounting Organizations and Society, 18, 2/3, 231252.

Sharma A. K. \& Talwar, B. (2004), "Business excellence enshrined in Vedic (Hindu) philosophy”, Singapore Management Review, 26, 1, 1-19.

Sharma A. K. \& Talwar, B. (2005), "Corporate social responsibility: Modern visà-vis Vedic approach", Measuring Business Excellence, 9, 1, 35-45.

Sharma A. K. \& Talwar, B. (2007), "Evolution of "Universal Business Excellence Model" incorporating Vedic philosophy", Measuring Business Excellence, 11, 3, 4-20.

Shearer, T. (2002), "Ethics and accountability: From the for-itself to the for-theother", Accounting, Organizations and Society, 27, 541-573.

Sheldon, K. M. \& Kasser, T. (1995), “Coherence and congruence: Two aspects of personality integration", Journal of Personality and Social Psychology, 68, 531-543. 
Sheldon, K. M. \& Kasser, T. (1998), "Pursuing personal goals: Skills enable progress, but not all progress is beneficial", Personality and Social Psychology Bulletin, 24, 1319-1331.

Sheldon, K. M. \& Kasser, T. (2001), “““Getting older, getting better”: Personal strivings and psychological maturity across the lifespan", Development Psychology, 37, 491-501.

Sihag, B. S. (2004), "Kautilya on the scope and methodology of accounting, organisational design and the role of ethics in ancient India”, The Accounting Historians Journal, 31, 2, 125-148.

Sihag, B. S. (2005), "Kautilya on ethics and economics", Humanomics, 21, 3/4, $1-28$.

Sihag, B. S. (2007), "Kautilya on institutions, governance, knowledge, ethics and prosperity", Humanomics, 23, 1, 5-28.

Smark, C. (2006), “Costing Schizophrenia”, Accounting Forum, 30, 341-358.

Stein, R. L. (2002), "On the possibility of an immediate of experience of God", Quodibet Journal, 4, 1, 108- 134.

Stern, P. C., Dietz, T. \& Guagnano, G. A. (1995), “The new ecological paradigm in socialpsychological context", Environmental Behaviour, 27, 723-743.

Stevenson, I. (1974), Twenty Cases Suggestive of Reincarnation, Charlottesville: University Press of Virginia.

Stevenson, I. (1987), Children Who Remember Their Past Lives, Charlottesville: University Press of Virginia.

Stevenson, I. (1997), Reincarnation and Biology: A Contribution to the Etiology of Birthmarks and Birth Defects, 2 vols., Westport: Praeger Publishers. 
Studstill, R. (2000), "Eliade, phenomenology and the sacred", Religious Studies, $36,2,177-194$.

Swanson, G. \& Gardner, J. (1986), “The inception and evolution of financial reporting in the Protestant Episcopal Church in the United States of America", The Accounting Historians Journal, 13, 2, 55-63.

The Coke-a-Cola Company, (2008), 2007 Annual Review, Georgia: The Coke-aCola Company.

Tigunait, R. (1983), Seven Systems of Indian Philosophy, Honesdale: Himalayan Press.

Tinker, T., Lehman, C. \& Neimark, M. (1991), "Falling down the hole in the middle of the road: Political quietism in corporate social reporting", Accounting, Auditing and Accountability Journal, 4, 2, 28-54.

United Nations Development Program, (1999), United Nations Human Development Report 1999, New York: United Nations Development Program.

Veenhoven, R. (1993), Happiness in Nations: Subjective Appreciation of Life in 56 Nations, 1946-1992, Rotterdam: Eramus University Press.

Velayutham S. \& Perera M. H. B. (1996), "The influence of underlying metaphysical notions on our interpretation of accounting", Accounting, Auditing \& Accountability Journal, 9, 4, 65-85.

Wachtel, P. L. \& Blatt, S. J. (1990), "Perceptions of economic needs and of anticipated future incomes", Journal of Economic Psychology, 11, 403415. 
Weale, A. (1992), "Homo Economicus, Homo Sociologicus", In Heap, S. H., Hollis, M., Lyons, B., Sugden R. \& Weale A. (Eds.), The Theory of Choice: A Critical Guide, Oxford: Wiley-Blackwell.

Wesley, J. (1956), In Sugden, E. H. (Ed.), The Standard Sermons of John Wesley, two Volumes, London: Epworth Press.

Wilkening E. A., McGranahan, D. (1978), "Correlates of subjective well-being in Northern Wisconsin", Social Indicators Research, 5, 1-4, 211-234.

Wilson, E. M. (1997), "Mantra and meanings", Journal of Managerial Psychology, 12, 8, 520-528.

Wolf, D. B. (1999), "A psychometric analysis of the Three Gunas", Psychological Reports, 84, 1379-1390. 